\title{
Reconceptualizing Sexual Harassment
}

\author{
Vicki Schultz ${ }^{\dagger}$
}

\author{
CONTENTS
}

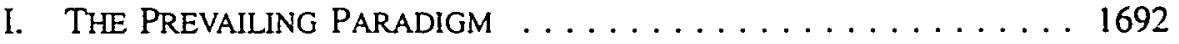

A. The Sexual Desire-Dominance Paradigm . . . . . . . . 1692

B. Origins of the Paradigm . . . . . . . . . . . . . 1696

1. Early Radical Feminist Ideas . . . . . . . . . . . 1696

2. Early Quid Pro Quo Harassment Cases ......... . 1701

C. An Illustration from the Case Law . . . . . . . . . . . . . 1706

II. The Sexualization of the Hostile WORK EnVironment . . . 1710

A. The Supreme Court's Decision in Harris v. Forklift Systems . 1710

B. Disaggregation in the Lower Courts . . . . . . . . . . . . 1713

1. Hostile Work Environment Versus Disparate Treatment . . 1714

2. "Sexual" Versus "Nonsexual" Conduct . . . . . . . . . 1716

C. The Harms of Disaggregation . . . . . . . . . . . . 1720

D. Sexual Paternalism and the Unwelcomeness Requirement . . 1729

E. The McKinney Rule and Its Lack of Influence . . . . . . . . 1732

$\div$ Professor, Yale Law School. This Aricle has been a long ume in the making; th was concetved as part of my earlier work on job segregation by sex. As a conseyuence of its long gestation, 1 will no doubt forget to thank many friends and colleagues whose conversations have encouraged me and enriched my thinking. I would like to express my appreciation-and admiration-for the numerous women who have shared with me their stories of struggle, demoralization, and triumph as they endeavored to pursue theur life's work in settings where they were unwelcome or underappreciated. Denuce Denton has been a particular inspiration. I am grateful also for thoughtful comments from participants at the Yale Law School faculty workshop, the University of Pennsylvania Legal Theory Workshop. the Law and Soctely Summer Institute, and the Westem New England School of Law Clason Speaker Series, as well as from Anne Alstot, Mark Barenberg, Drew Days, Carol Rose, Jeremy Paul. Reva Siegel, and especially Bruce Ackerman. In addition, I would like to thank a number of students who provided superb research assistance: Carolyn Bernstein, Jackie Rolfs, the late Markie Rath. Alex Klass. Beth Kransberger, Cathy Bowman, Nicole Guèron, Marjorie Allard, Darren Reisberg, and especially Susie Schmeiser and Glenn Edwards. My thanks go also to the Fund for Labor Relations Studies for financial assistance.

I dedicate this piece to Natalie Virginia Schultz-Henry, who was almost as long in the making as thus Article. May she come of age in a world in which she is free to pursue her aspirauons in a communty in which men and women work alongside each other as equals.

As this Article went to press, the Supreme Coun issued a unanımous opinon in Oncale y Sundowner Offshore Services, Inc., No. 96-568, 1998 WL 88039 (U.S. Mar. 4. 1998), holding that same-sex harassment may constitute discrimination because of sex in violation of Title VII of the Civil Rights Act. Although time and space limitations prevent me from exploring the implications of the Oncale decision for this Article, it is important to emphasize that the result and reasoning of the case conform to, and in fact provide added support for, the analysis proposed herein. For further discussion, see infra notes 18, 595. 
III. THE INVISIBILITY OF GENDER AT WORK . . . . . . . . . . . . . 1738

A. The Two-Tiered Structure of Causation . . . . . . . . . . . 1739

B. Sexuality as a Bright-Line Test for Gender-Based Conduct? . 1744

C. The Courts' Failure To Understand the Role of Work in Producing Gender Inequality . . . . . . . . . . . . 1748

IV. AN ALTERNATIVE ACCOUNT OF HOSTILE WORK ENVIRONMENT HARASSMENT: A COMPETENCE-CENTERED PARADIGM $\ldots \ldots \ldots 1755$

A. The Link Between Job Segregation and Hostile Work Environments ..................... 1756

B. The Competence-Undermining Function of Hostile Work Environment Harassment . . . . . . . . . . . . . . . . 1762

C. Reconceptualizing the Harassment of Women Workers ... . 1769

V. Additional AdVANTAges of the COMPETENCE-CENTERED ACCOUNT . . . . . . . . . . . . . . . . . . 1774

A. Revealing the Actionable Features of Male-on-Male Harassment . . . . . . . . . . . . . . . . . . . 1774

B. Reducing the Risk of Prohibiting Benign Sexual Expression . 1789

VI. Conclusion: Toward IMPLEMENTing the NEW ACCOUNT $\ldots$. . 1796 
It's a form of harassment every time I pick up a sledgehammer and that prick laughs at me, you know. It's a form of harassment when a journeyman is supposed to be training me and it's real clear to me that he does not want to give me any information whatsoever. He does not want me to be there at all ... . They put me with this one who is a lunatic... he's the one who drilled the hole in my arm .... It's a form of harassment to me when the working foreman puts me in a dangerous situation and tells me to do something in an improper way and then tells me, Oh, you can't do that! It's a form of harassment to me when someone takes a tool out of my hand and said,... I'll show you how to do this, and he grabs the sledgehammer from my hand and he proceeded to try to show me how to do this thing ... you know, straighten up a post ... it's nothing to it, you just bang it and it gets straight .... It's a form of harassment to me when they call me honey and I have to tell them every day, don't call me that, you know, I have a name printed right on my thing. ... Ah, you know, it's all a form of harassment to me. It's not right. They don't treat each other that way. They shouldn't treat me that way. It's a form of harassment to me when this one asks me to go out with him all the time. You know, all this kind of stuff. It's terrible.'

How should we understand sex-based harassment on the job? Its existence is now part of the national consciousness. Over the past twenty years, feminists have succeeded in naming "sexual harassment" and defining it as a social problem. ${ }^{2}$ Popular accounts abound: Newspapers, movies, and television programs depict women workers who are forced to endure sexual advances and decry the fact that these women must contend with such abuse. ${ }^{3}$ The legal system, too, has recognized the problem. The Supreme Court, on two separate occasions, ${ }^{4}$ has affirmed that workplace sexual harassment violates Title VII of the Civil Rights Act, ${ }^{5}$ and the lower federal courts have created a massive

1. Mary lindenstein Walshok, Blue Collar Women: Pioneers on tile Male Frontier 221 -22 (1981) (quoting a female welder).

2. Working Women United (WWU) is the first group known to have used the term "sexual harassment." In May of 1975, WWU held a "Speak-Out on Sexual Harassment," for purposes of which it defined sexual harassment as "the treatment of women workers as sexual objects." Dierdre Silverman. Sexual Harassment: Working Women's Dilemma, QUEST. FEMINIST Q. Winter 1976-1977, at 1S, 15.

3. For examples of recent newspaper articles depicting sexual harassment in negative terms, see Jane Daugherty, Sexual Harassment Takes a Devastating Toll. Detrort News, Jan. 28. 1997. al D1: Lisa Hoffman, Sex Harassment Last Straw for Career Soldier: Woman Finally Left Amy out of Frustration. Anger, ROCKY MOUNTAIN NEwS, Feb. 16, 1997, at 3A; and A Afission for the Military. BOSTON GLOBE, Feb. 7, 1997, at A18. The Lifetime television network produced a movie told from the perspective of Kerry Ellison, the plaintiff in Ellison v. Brady, 924 F.2d 872 (9th Cir. 1991). See Hostile Advances: The Kerry Ellison Story (Lifetime television broadcast, May 27, 1996). But see DAvid MAMET, OlEANNA (1992) (depicting sympathetically a male professor accused of sexual harassment by a female college student).

4. See Harris v. Forklift Sys., Inc., 510 U.S. 17 (1993); Meritor Sav. Bank v. Vinson. 477 U.S. 57 (1986).

5. 42 U.S.C. \& 2000e (1994). Title VII reads in relevant par:

It shall be an unlawful employment practice for an employer . . . to fail or refuse to hire or to discharge any individual, or otherwise to discriminate against any individual with respect to his compensation, terms, conditions, or privileges of employment, because of such individual's mee. 
body of doctrine detailing the law's protection. All the while, public awareness of legal rights has continued to develop, and workers have filed sexual harassment complaints in increasing numbers. ${ }^{6}$

That feminists (and sympathetic lawyers) have inspired a body of popular and legal opinion condemning harassment in such a brief period of time is a remarkable achievement. Yet the achievement has been limited because we have not conceptualized the problem in sufficiently broad terms. The prevailing paradigm for understanding sex-based harassment places sexuality-more specifically, male-female sexual advances-at the center of the problem. Within that paradigm, a male supervisor's sexual advances on a less powerful, female subordinate represent the quintessential form of harassment.

Although this sexual desire-dominance paradigm represented progress when it was first articulated as the foundation for quid pro quo sexual harassment, using the paradigm to conceptualize hostile work environment harassment has served to exclude from legal understanding many of the most common and debilitating forms of harassment faced by women (and many men) at work each day. ${ }^{7}$ The prevailing paradigm privileges conduct thought to be motivated by sexual designs-such as sexual advances-as the core sexor gender-based harassment. ${ }^{8}$ Yet much of the gender-based hostility and

color, religion, sex, or national origin; or ... to limit, segregate, or classify his employees or applicants for employment in any way which would deprive or tend to deprive any individual employee of employment opportunities or otherwise adversely affect his status as an employec, because of such individual's race, color, religion, sex, or national origin.

Id. $\S 2000 \mathrm{e}-3$.

6. See Kirstin Downey Grimsley, Worker Bias Cases Are Rising Steadily; New Laws Boost Hopes for Monetary Awards, WASH. POST, May 12, 1997, at Al (noting that the fastest growing area of employment discrimination complaints is sexual harassment, up from 6127 complaints in 1990 to 15.342 complaints in 1996); Allen R. Myerson, As Federal Bias Cases Drop, Workers Take Up the Fight, N.Y. Times, Jan. 12, 1997 , \& 1, at 1 (noting that the new bias cases often are more about pay, promotion, and harassment than about hiring, and increasingly concern sex rather than race).

7. Title VII jurisprudence recognizes two different types of sex-based harassment: (1) quid pro quo harassment, in which a supervisor seeks to condition employment benefits on a subordinate's grant of sexual favors; and (2) hostile work environment harassment, in which supervisors or coworkers engage in conduct that is "sufficiently severe or pervasive 'to alter the conditions of [the victim's] employment and create an abusive working environment." Vinson, 477 U.S. at 67 (quoting Henson v. City of Dundec, 682 F.2d 897, 904 (11 th Cir. 1982)).

8. Throughout this Article, I use the terms "gender" and "sex" interchangeably. I use the terms to refer to the complex process of socializing human beings into the identities of men and women, to the clement of social relationships based on differences that society attributes to people with those two identities, and to the process of signifying power through those identities. See JOAN WALLACH SCOTT, GENDER AND THE POLITICS OF HISTORY 28-50 (1988), for the views that come perhaps closest to capturing my own.

For many years, feminists distinguished between "sex"- the biological sex of a human being-and "gender"- the different social and cultural expectations and roles assigned to the sexes. Recently, this distinction has come under challenge, as some feminists have questioned whether it makes sense to refer to "sex" as an ontologically given category that we can comprehend free of perceptions that have already been gendered. See, e.g., JUDITH BUTLER, GENDER TROUBLE: FEMINISM AND THE SUBVERSION OF IDENTITY (1990). For purposes of this Article, I need not take a position in this debate. Regardless of whether something endowed by nature called "sex" can be known with any certainty, it is clear that the legal system cannot ascertain it with any certainty. Thus, Title VII's protection against discrimination based on "sex" has ultimately, and necessarily, been construed to protect people from discrimination based on "gender," even though some courts may cling to the notion that they can discover natural sex differences that justify differential treatment. See Katherine M. Franke, The Central Mistake of Sex Discrimination Law: The 
abuse that women (and some men) endure at work is neither driven by the desire for sexual relations nor even sexual in content.

Indeed, many of the most prevalent forms of harassment are actions that are designed to maintain work-particularly the more highly rewarded lines of work - as bastions of masculine competence and authority. Every day, in workplaces all over the country, men uphold the image that their jobs demand masculine mastery by acting to undermine their female colleagues' perceived (or sometimes even actual) competence to do the work. The forms of such harassment are wide-ranging. They include characterizing the work as appropriate for men only; denigrating women's performance or ability to master the job; providing patronizing forms of help in performing the job; withholding the training, information, or opportunity to learn to do the job well; engaging in deliberate work sabotage; providing sexist evaluations of women's performance or denying them deserved promotions; isolating women from the social networks that confer a sense of belonging; denying women the perks or privileges that are required for success; assigning women sex-stereotyped service tasks that lie outside their job descriptions (such as cleaning or serving coffee); engaging in taunting, pranks, and other forms of hazing designed to remind women that they are different and out of place; and physically assaulting or threatening to assault the women who dare to fight back. Of course, making a woman the object of sexual attention can also work to undermine her image and self-confidence as a capable worker. Yet, much of the time, harassment assumes a form that has little or nothing to do with sexuality but everything to do with gender. As the female welder quoted above put it, "Ah, you know, it's all a form of harassment to me. . . They don't treat each other that way. They shouldn't treat me that way."

In spite of the female welder's intuitive understanding that all these actions are gender-based forms of harassment, there has been little or no recognition of such a perspective in the law. Most feminists and other scholars sympathetic to working women have either explicitly advocated or implicitly accepted the prevailing sexual desire-dominance paradigm. This is not surprising, for feminists played a prominent role in creating it. The focus on sexual conduct emerged from an early radical feminist critique of heterosexual relations as a primary producer of women's oppression. These early feminists saw rape as a central metaphor for men's treatment of women, and they compared sexual harassment to rape. ${ }^{10}$ More recently, feminist legal scholars have analogized the law governing workplace harassment to rape law, criticizing harassment law for its disregard of women's perspectives on sexuality and for its failure to appreciate the unique harm inherent in the fact that harassment is a sexual

Disaggregation of Sex from Gender, 144 U. PA. L. REV. 1 (1995) (arguing that antudiscnmination law incorrectly proceeds from the assumption of biological sex difference).

9. WALSHOK, supra note 1, at 222: see supra text accompanying nole 1.

10. See infra notes 58-69 and accompanying text. 
violation. ${ }^{11}$ Just as feminist analyses have conceived of harassment as sexual abuse, most scholars who have addressed same-sex harassment have characterized it in sexualized terms, analogizing same-sex harassment to heterosexual sexual advances as an argument for legal regulation. ${ }^{2}$ Thus, even the most critical accounts of harassment law, like other accounts of workplace harassment, ${ }^{13}$ have assumed a sexuality-centered perspective that portrays sexual advances and other sexually oriented conduct as the core of the problem. ${ }^{14}$ They are rooted in the prevailing paradigm. ${ }^{15}$

11. One of the clearest statements of this position appears in Susan Estrich's powerful article, Susan Estrich, Sex at Work, 43 STAN. L. REv. 813 (1991). As Estrich writes:

What makes sexual harassment more offensive, more debilitating, and more dehumanizing to its victims than other forms of discrimination is precisely the fact that it is sexual. Not only are men exercising power over women, but they are operating in a realm which is still judged according to a gender double standard, itself a reflection of the extent to which sexuality is used to penalize women. In my view, [harassment] cases are such a disaster in doctrinal terms precisely because, as with rape, they involve sex and sexuality.

Id. at 820. For additional examples of this perspective, see Caroline Forell, Essentialism, Empathy, and the Reasonable Woman, 1994 U. ILL. L. REV. 769; Ann C. Juliano, Note, Did She Ask for It?: The "Unwelcome" Requirement in Sexual Harassment Cases, 77 CORNELL L. REV. 1558 (1992); and Miranda Oshige, Note, What's Sex Got To Do with It?, 47 STAN. L. REV. 565 (1995). Cf. Richard A. Posner, An Economic Analysis of Sex Discrimination Laws, 56 U. CHI. L. REv. 1311, 1318 (1989) (arguing that sexual harassment is "more clearly akin to ... rape than to misogynistic refusal to accept women workers").

12. See, e.g., Charles R. Calleros, The Meaning of "Sex": Homosexual and Bisexual Harassment Under Title VII, 20 VT. L. REv. 55 (1995); Samuel A. Marcosson, Harassment on the Basis of Sexual Orientation: A Claim of Sex Discrimination Under Title VII, 81 GEO. L.J. I (1992); Lisa Wehren, Note, Same-Gender Sexual Harassment Under Title VII: Garcia v. Elf Atochem Marks a Step in the Wrong Direction, 32 CAL. W. L. REV. 87 (1995).

13. Most of the large-scale empirical studies of sex-based harassment have also used a sexualized definition of harassment limited to sexual advances and other conduct of a sexual nature. See, e.g., BARBARA GUTEK, SEX AND THE WORKPLACE: THE IMPACT OF SEXUAL BEHAVIOR AND HARASSMENT ON WOMEN, MEN, AND ORganizations (1985); U.S. MERIT SyS. PROTECTION BD., SEXUal Harassment IN THE FEDERAL GOVERNMENT: AN UPDATE (1988) [hereinafter SEXUAL HARASSMENT IN THE FEDERAL GOVERNMENT]; U.S. MERIT SYS. PROTECTION BD., SEXUAL HARASSMENT IN THE FEDERAL WORKPLACB: IS IT A PROBLEM? (1981) [hereinafter SEXUAL HARASSMENT IN THE FEDERAL WORKPLACE]; WaLSHOK, supra note 1; see also Patricia A. Frazier et al., Social Science Research on Lay Definitions of Sexual Harassment, 51 J. SOC. ISSUES 21 (1995) (citing numerous studies of harassment that utilize a sexualized definition).

14. A few writers have urged courts to construe Title VII broadly to prohibit all forms of gender-based harassment, rather than focusing narrowly on sexual advances and other sexual conduct. See, e.g., L. Camille Hébert, Sexual Harassment is Gender Harassment, 43 U. KAN. L. REV. 565 (1995); Frank S. Ravitch, Contextualizing Gender Harassment: Providing an Analytical Framework for an Emerging Concept in Discrimination Law, 1995 DET. C.L. REV. 853. Even such writers, however, have found it difficult to escape the prevailing sexual paradigm. Some, for example, continue to make an artificial analytical distinction between gender-based harassment and sexual harassment. See, e.g., Ravitch, supra, at 856-57. Others subtly continue to highlight the sexual nature of harassment as a reason for condemning it, even though they purport to understand harassment as a form of sexism rather than sexuality. See, e.g., Hébert, supra, at 587. None of these writers advances an account of harassment that highlights its role in preserving job segregation by constructing gender-based differences in work competence, as I do here.

15. A notable exception is Carlin Meyer, Feminism, Work and Sex: Retuming to the Gates (1995) (unpublished manuscript, on file with author). Meyer insightfully discusses how feminist legal theorists' emphasis on sexual harassment has neglected other fundamental work-related problems of concem to women, such as sweatshops, occupational health and safety, pension issues, and the rise of home work and contingent labor. See id. at 8-10. This Article, by contrast, shows how the courts' utilization of a feminist-inspired paradigm to regulate sexual forms of harassment has neglected equally pernicious, nonsexual forms of gender-based misconduct in the workplace-particularly conduct that denigrates women's competence and thereby preserves work along gendered lines. 
This Article challenges the sexual desire-dominance paradigm. A comprehensive examination of Title VII hostile work environment harassment cases demonstrates the paradigm's inadequacy. Despite the best intentions of its creators, the paradigm has compromised the law's protection. Principal among its drawbacks, the paradigm is underinclusive: It omits-and even obscures-many of the most prevalent forms of harassment that make workplaces hostile and alienating to workers based on their gender. Much of what is harmful to women in the workplace is difficult to construe as sexual in design. Similarly, many men are harmed at work by gender-based harassment that fits only uneasily within the parameters of a sexualized paradigm. The prevailing paradigm, however, may also be overinclusive. By emphasizing the protection of women's sexual selves and sensibilities over and above their empowerment as workers, the paradigm permits—or even encourages-companies to construe the law to prohibit some forms of sexual expression that do not promote gender hierarchy at work. The focus of harassment law should not be on sexuality as such. The focus should be on conduct that consigns people to gendered work roles that do not further their own aspirations or advantage.

The Article proceeds as follows. Part I begins by describing the sexual desire-dominance paradigm for conceptualizing hostile work environment harassment. It traces the roots of the paradigm in early feminist thought and in the reasoning of early cases. As Part I shows, the major jurisprudential barrier to recognizing a Title VII cause of action for quid pro quo harassment was some courts' initial reluctance to hold that supervisors' demands for sexual favors occurred "because of sex" within the meaning of the statute. Influenced by radical feminist thought that highlighted the centrality of sexual exploitation in creating women's inequality, feminists argued, and courts began to recognize, that supervisors' sexual advances can constitute sex- or gender-based discrimination. The resulting legal analysis was grounded in sexual desire: A heterosexual male supervisor's advances toward a female subordinate were based on sex because the supervisor would not make similar sexual advances toward a man. This desire-based reasoning laid the foundation for the prevailing paradigm.

To some extent, the sexual desire-dominance paradigm represented progress. It was important for courts to recognize that gender discrimination can take the form of sexual overtures. But the paradigm also portended problems. By emphasizing sexual abuse, the paradigm threatened to eclipse other, equally harmful forms of gender-based hostility. As Parts II and III demonstrate, this concern has materialized. Part II documents the problem of disaggregation: Courts consider only sexual advances or other sexual conduct for purposes of establishing hostile work environment harassment, and they consign less sexual forms of misconduct to a separate disparate treatment analysis (if they consider such forms at all). Disaggregation obscures a full 
view of the conditions of the workplace and makes both the hostile work environment and disparate treatment claims look trivial. When severed from a larger pattern of discriminatory conduct, sexual advances or ridicule can appear insufficiently severe or pervasive to be actionable. By the same token, when severed from sexual overtures, nonsexual forms of harassment may appear to be gender-neutral hazing that has nothing to do with the victims' womanhood. Indeed, when women are denied the training or support to succeed on the job, they can easily be made to appear (or even become) less than fully proficient at their jobs. This lack of proficiency then becomes the justification for the very mistreatment that has undermined their performance.

Part III examines the question of causation. Ironically, courts that once refused to recognize that sexual advances may occur because of sex now insist on such advances and fail to perceive many other problems that confront women workers as sex-based. Courts often search for deep-seated sexual motivations for women's adverse treatment when gender-based considerations lie close to the surface. Yet the courts' focus on sexual conduct has not provided judges with a bright-line test; their inevitable disagreement about whether challenged conduct is sufficiently sexual has created as many inconsistencies as it has criteria for guidance. Thus, I argue that the judicial focus on sexual conduct is not fueled by a beneficial certainty in line drawing, but by judges' failure to comprehend the significance of workplace discrimination in creating women's disadvantage.

The courts' traditional failure to comprehend the magnitude of women's gender troubles at work, in fact, has only been exacerbated by the prevailing paradigm's emphasis on sexual forms of harassment. Singling out sexual advances as the essence of workplace harassment has allowed courts to feel enlightened about protecting women from sexual violation, while at the same time relieving judges of the responsibility to redress other, broader gender-based problems in the workplace. It is not enough to focus on the harm to women as sexual beings; the law must also address women's systematic disadvantage-and facilitate women's equal empowerment-as creative, committed workers. We need an account of hostile work environment harassment that highlights its dynamic relationship to larger forms of gender hierarchy at work.

Part IV advances a new account of hostile work environment harassment that emphasizes its role in reproducing work and work competence along masculine and feminine lines. In this account, harassment is not driven by a need for sexual domination but by a desire to preserve favored lines of work as masculine. By maintaining a hold on highly rewarded employment, men secure a host of advantages in and outside the workplace. Some of these advantages are material: Wage superiority over women, for example, ensures men's position at the head of the household as well as their place at the helm of most powerful institutions in society. Equally significant are powerful 
psychological factors: Both breadwinning and work competence are central to the dominant cultural understandings of manhood. By protecting their jobs from incursion by women, or by incorporating women only on inferior terms, men sustain the impression that their work requires uniquely masculine skills. Maintaining their jobs as repositories of masculine mastery, in turn, assures men a sense of identity (even superiority) as men.

In this new account, hostile work environment harassment is closely linked to job segregation by sex. Harassment serves a gender-guarding, competence-undermining function: By subverting women's capacity to perform favored lines of work, harassment polices the boundaries of the work and protects its idealized masculine image-as well as the identity of those who do it. As a female pipefitter explained:

You see it is just very hard for them to work with me because they're really into proving their masculinity .... And when a woman comes on a job that can work, get something done as fast and efficiently, as well, as they can, it really affects them. Somehow if a woman can do it, it ain't that masculine, not that tough. ${ }^{16}$

This analysis applies across occupational and class lines to blue-collar and white-collar work, in high and low places. From medicine to sales to construction, from boardrooms to restaurants to firehouses, from managers to coworkers to subordinates, male workers have created environments that cast doubt upon the capability of women who threaten the masculine privilege and personae of their work.

As Part V shows, such harassment is not only directed at women, but also targets men who threaten the work's masculine image. Just as some male workers seek to protect their work from encroachment by women, so too may male workers seek to denigrate and drive away other men who detract from the perception of their jobs as the embodiment of an idealized manly competence. Part V argues that, regardless of whether male harassees are targeted or taunted on the basis of alleged homosexuality or on the basis of other characteristics that the dominant male workers see as representing a lack of manliness (and fear will diminish their own), such harassment is based on gender within the meaning of Title VII. As the Supreme Court has instructed, the statute prohibits pressuring people to conform to preconceived notions of appropriate manhood or womanhood in connection with their work. ${ }^{17}$ Yet the (1985).

16. Jean Schroedel, alone in a Crowd: Women in the Trudes Tell their Stories $20-21$

17. See Price Waterhouse v. Hopkins, 490 U.S. 228, 250-51 (1989) (construing Title VIl to prohibit gender stereotyping in the form of pressuring a female accountant to conform to stereolypically feminine demeanor and appearance in order to be promoted to partner). 
law has not yet clearly recognized that male-on-male harassment that exerts such pressure is a form of gender discrimination prohibited by Title VII. ${ }^{18}$

It is time for a reconceptualization of sex-based harassment-and harassment law-along more comprehensive lines. It is time to focus on gender along with sexuality, on the monopolization of work competence along with sexual abuse. Part VI sketches some suggestions for how courts and lawyers might implement the new competence-centered account of hostile work environment harassment. That task involves returning to Title VII's original purpose, which was to empower everyone-whatever their sex or gender-to pursue their life's work on equal terms.

\section{THE PREVAILING PARAdIGM}

\section{A. The Sexual Desire-Dominance Paradigm}

The prevailing paradigm defines unwanted heterosexual sexual advances as the core conduct that constitutes sex-based harassment. The quintessential case of harassment involves a more powerful, typically older, male supervisor, who uses his superior organizational position to demand sexual favors from a less powerful, typically younger, female subordinate. Sometimes, his motivation is sexual desire: He wants her, and he uses his organizational position to get her. Sometimes, it is a desire to subordinate: He wants to make sure she remains below him in the workplace hierarchy, and he uses sexuality to reinforce his position. Either way, his actions are an abuse of his power and an abuse of her sex. Within this paradigm, heterosexual desire and male dominance are inextricably linked. Men use their dominant positions at work to extract sex from women, and extracting sex from women ensures their dominance.

This sexual desire-dominance paradigm governs our understanding of harassment. Its influence is reflected in the very fact that the category is referred to as "sexual" harassment rather than, for example, "gender-based" or "sex-based" harassment. The most publicized harassment cases have accentuated this understanding. The Anita Hill-Clarence Thomas controversy was the first case to receive widespread public attention, and it solidified the view of harassment as sexual pursuit and predation. Hill, a reserved woman who was at the time of the alleged events a novice lawyer in her mid-twenties,

18. The Supreme Court's unanimous opinion in Oncale v. Sundowner Offshore Services, Inc., No. 96-568, 1998 WL 88039 (U.S. Mar. 4, 1998), which was issued as this Article went to press, sends a promising new signal to the lower courts. In Oncale, the Court reversed a Fifth Circuit decision that had held that male-on-male harassment is never actionable under Title VII. The Court concluded that "nothing in Title VII necessarily bars a claim of discrimination 'because of ... sex' merely because the plaintiff and the defendant . . . are of the same sex." Id. at *2 (quoting 42 U.S.C. $\$ 2000-e(a)(1)$ (1994)). In line with the argument of this Article, the Court also made clear that "harassing conduct need not be motivated by sexual desire to support an inference of discrimination on the basis of sex." Id. at *4. 
claimed that Thomas, her then-supervisor at the Department of Education and subsequent Chair of the Equal Employment Opportunity Commission (EEOC), had pressured her repeatedly to go out with him. ${ }^{19}$ After a while, Thomas "began to use work situations to discuss sex," regaling Hill with lewd accounts of pornographic films and of his own sexual proclivities and prowess. ${ }^{20}$ Hill's testimony at Thomas's confirmation hearings suggested that she believed the harassment to be driven by a need for domination: "I never felt that [Thomas] was genuinely interested in me-only in coercing me." ${ }^{21}$ Thomas agreed that the alleged conduct constituted actionable harassment, but described it as the expression of a perverse kind of sexual desire. According to his supporters, a person who did what Hill claimed would be a "psychopathic sex fiend or a pervert." ${ }^{22}$ This interpretation allowed Thomas to deny that he had ever engaged in the alleged conduct: "If I were going to date someone outside of the workplace... I would certainly not approach [her] with this kind of grotesque language." ${ }^{23}$ Although Thomas stressed sexual desire and Hill suggested domination, both parties-seasoned veterans of the EEOC familiar with the legal conception of harassment-took for granted the prevailing paradigm defining sexual advances as the core workplace harassment.

Other well-known harassment cases have followed the same pattern. In October 1991, the same month that the Thomas confirmation hearings riveted the nation, the news media broke the Tailhook story. In a corridor of the Las Vegas Hilton, during the Tailhook Association's raucous annual convention, seventy Navy and Marine aviators pushed more than two dozen women, some of them Navy officers, down a gauntlet in which the drunken men shouted sexually suggestive remarks, ripped at the women's clothes, and groped at their bodies. ${ }^{24}$ Widely referred to as a "sex abuse" scandal, "Tailhook's lurid details captured the country's attention: "Tailhook ... was the scandal that opened the Pandora's box on a problem that has festered for decades." ${ }^{26}$ The way the problem was defined, however, reveals much about the reigning

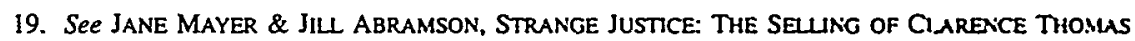
95 (1994).

20. Id. at 96.

21. Id at 97.

22. The Thomas Nomination; Excerpts from Senate's Hearings on the Thomes Nomination. N.Y. TIMES, Oct. 13, 1991, at A30 (quoting a statement of Sen. Orrin Hatch).

23. Id. (quoting a statement of Judge Clarence Thomas).

24. See John Lancaster, Navy 'Gauntlet' Probed; Sex Harassment Alleged at Fliers' Convention, WASH. Post, Oct. 30, 1991, at Al; H.G. Reza, Women Accuse Navy Pilots of Harassment. LA. MMES, Oct. 30, 199!, at Bl.

25. E.g., Admiral Is Relieved of Duty for Delay in Sex Abuse Case, N.Y. TIMES, Nov. 6. 1991. at A23; Melissa Healy, Pentagon's Tailhook Report Expected To Detail Obstruction. Cover.Up: Scandal: Separate Inquiry Will Deal with Specific Charges in the Sexual Abuse of Women at an Aviators Convention, L.A. TIMES, Sept. 16, 1992, at A14; Navy Cuts Ties to Group in Sex Abuse Case. N.Y. TIMES, Oct. 31, 1991. at A20; Sex Abuse Incident Brings Admiral Permanens Penaly. LA. TIMes. Dec. 21. 1991. at A20; Sexual Abuse in the Military, CHI. TRIB., July 5, 1992, at 2.

26. Letta Tayler, Operation: Parity; Assaults Renew Debate on Role of Women, NEwSDAY, July 27. 1992 , at 6. 
paradigm. For years, researchers have documented wide-ranging forms of discrimination, harassment, and second-class treatment of women in the armed forces. Yet public officials have not focused on these broader practices, but have singled out the problem of sexual abuse. The Senate Veterans Affairs Committee, for example, heard testimony on the issue of sexual abuse in the military, while newspapers decried the "armed force[s' failure] to protect women from sexual exploitation by military personnel whose orders they are supposed to obey."27 Veterans' centers established programs for victims of sexual trauma, ${ }^{28}$ and the Navy set up a hot line and a system for tracking complaints of sexual harassment, assault, and rape. ${ }^{29}$ All the while, newspapers continued to report new incidents of sexual abuse in the military, ${ }^{30}$ while devoting far less coverage to other, equally debilitating forms of discrimination. In fact, some sources cited sexual exploitation as a reason to question the wisdom of integrating women into the armed forces, rather than as a sign of the need for broad structural reforms to facilitate women's integration on more equal and empowering terms. ${ }^{31}$

Press coverage of a lawsuit against Stroh's Brewery also reveals a fixation on sexual abuse and the neglect of other discriminatory workplace dynamics. In November 1991, several women who worked at a St. Paul, Minnesota bottling plant owned by Stroh's filed a lawsuit alleging a hostile work environment and denial of job advancement. ${ }^{32}$ Newcomers to the traditionally masculine preserve of beer making, the women were subjected to a series of severe acts of hostility. They were told that women could not hold certain jobs

27. Sexual Abuse in the Military, supra note 25; see also Elaine Sciolino, Military Women Report Pattern of Sexual Abuse by Servicemen, N.Y. TIMES, July 1, 1992, at A1; The Sexual Abuse of Servicewomen, Boston GloBE, July 8, 1992, at 12; Soldiers and Sex Abuse, HARTFORD CouRANT, July 7, 1992, at B10.

28. See Patricia Dibsie, VA Emphasizes Sexual Trauma Care for Women, SAN DiEgo UNION-TRIB., Sept. 28, 1994, at B1; Dave Moniz, Veterans of Hell; Nightmares of Rape Haunt Female Ex-Gls, CHI. TRIB., Nov. 19, 1995 , at 10.

29. See Navy Acts To Improve Women's Lot: 80 Recommendations To Be Implemented, ST. LouIS PosT-DisPATCH, Oct. 14, 1992, at 10A.

30. See, e.g., Tom Bowman \& Gilbert A. Lewthwaite, Victims List Grows to 34 at Aberdeen: Female Soldiers Alleging Misconduct Double from 17; Hot Line Logs 5,204 Calls; Panel of Military and Civilians Named To Study Army Culture, BALTIMORE Sun, Nov. 23, 1996, at 1A; Nancy Ann Jeffrey, Rankling the Ranks: The Battle over Sexual Harassment Rages on in the Military, CHI. TRIB., Nov. 1, 1992, at 4; Michael Kilian, New Sex Scandal Hits Army Ranks: 3 Charged at Second Training Site, CHI. TRIB., Nov. 13, 1996, at 1; Ann LoLordo, Woman GI Fights Private War over Sex Assault Case, SACRAmento BeB, Mar. 29, 1993, at A1; Dana Priest, Abuse in Army 'Not That Unusual': Sexual Misconduct by Trainers Long-Standing Problem for Military, WASH. POST, Nov. 21, 1996, at A1; Andrea Stone; Women in Military: Sex Harassment and Silence, USA TODAY, July 23, 1992, at 6A; West Point Students Claim Sexual Harassment, CHI. TRIB., Nov. 2, 1994, at 2.

31. See, e.g., Eric Schmitt, Bill Would Separate Men and Women in Basic Training, N.Y. TiMEs, May 18,1997 , at A20 ("With sex scandals breaking out all over the military, legislation to segregate men and women in basic training is gaining momentum in the House."); Elaine Sciolino, Sergeant Convicted of 18 Counts of Raping Female Subordinates, N.Y. TimES, Apr. 30, 1997, at A1 ("Today's verdict is certain to rekindle the debate on Capitol Hill and within the military about whether the American military's experiment with integrating men and women has failed.").

32. See Carol Kleiman, Harassment Suit at Stroh Brewery Puts Focus on Company's Own Ads, CHI. TRIB., Mar. 9, 1992, at 6. 
and that they should go home or get "women's jobs." ${ }^{33}$ They were referred to with demeaning epithets, like "bitch" and "squaw." 34 They were physically assaulted in both sexual and nonsexual ways: One woman was "grabbed ... on the rear end"; 35 a male coworker "displayed his pubic hair [to a second woman] and grabbed [her] head and pushed it down to his crotch"; ${ }^{36}$ a male coworker drove a forklift toward another woman; $; 3$ a fourth woman "was given an extra-heavy workload after she injured her back and requested light duty, and was intentionally exposed by a fellow worker to toxic chemicals";,38 several other women had their tools and machines sabotaged and their tires slashed or deflated by male coworkers who "stop[ped] to taunt them with gutter talk or just to watch their misery" while they "g[o]t . . down onto dir, ice or slush to fix the tires." ${ }^{39}$ In addition, the women were subjected to a barrage of sexual comments, graffiti, and pin-ups of the sort often thrust upon women in blue-collar, male-dominated workplaces. ${ }^{40}$ At Stroh's, the campaign of harassment was both vicious and successful. Ultimately, it drove all the women plaintiffs away from the plant. ${ }^{41}$

The Hill-Thomas controversy concerned sexual advances; Tailhook sexual assault. The Stroh's case had the potential to clarify that women's workplace troubles do not always assume such sexual forms. Yet, as Professor Carlin Meyer has shown, the media did not focus on the broader implications. ${ }^{.2}$ It sensationalized the one element of the case it found "sexy"-the allegation that Stroh's use of the "Swedish Bikini Team" in its advertising campaign had contributed to the harassment. Drawing on the company's traditional slogan, "It doesn't get any better than this," the advertisements featured a bikini-clad quintet of blonde women exclaiming, "It gets better," as they parachuted Old Milwaukee beer to a group of men out in the woods. ${ }^{43}$ The legal challenge to the advertisements invoked the sexual desire-dominance paradigm: The plaintiffs argued that the ads advanced a company-wide view of women as sexual objects, which in turn encouraged male workers to make sexual advances toward their female coworkers. ${ }^{\text {th }}$ Although the challenge to the

33. Tony Kennedy, Judge Says Stroh's Ad Strategies Won't Be Part of Harassmens Trial: Ads Not in Workplace To Be Excluded, Ruling States, STAR TR18. (Minneapolis), Nov. 9. 1993, at ID.

34. Kleiman, supra note 32.

35. Id.

36. Id.

37. See Meyer, supra note 15 , at 12.

38. Id at 13 .

39. Jean Steiner, There's More to Sexual Harassment than a Swedish Bikınt Team. STAR TRIB. (Minneapolis), Dec. 19, 1991, at 27A.

40. See Kleiman, supra note 32; Meyer, supra note 15, at 12.

41. See Meyer, supra note 15, at 11. The Stroh's sult ulumately sellled; the terms of the setllement were kept confidential. See id. at 12 n.37.

42. See id. at 14-15.

43. Swedish Bikini Team Taking Vacation from TV. STAR TRIB. (Minneapolıs). Feb. 14. 1992, at 2D (describing a Stroh's television commercial).

44. See, e.g., Edward Walsh. Stroh Workers Charge Ads Fuel Harassmen!: 'Bikin Team' TV Spots Prompt Lawsuits, WASH. POST, Nov. 30, 1991, at A3 ("When the company as a whole is treating women 
advertisements was only one small aspect of a complex case, the press treated the claim about the ads as if it were the case, announcing the lawsuit with such headlines as "Bikini Ad Prompts a Sexual Harassment Suit." As As in the Hill-Thomas controversy and the Tailhook incident, the media coverage of the Stroh's case reflected-and in turn reproduced-the prevailing, sexualitycentered paradigm.

\section{B. Origins of the Paradigm}

Where did the sexual desire-dominance paradigm come from? How did it come to have such a strong hold on our understanding of harassment? Although the origins of the paradigm are complex, ${ }^{46}$ an integral part of the story involves early feminists' struggle to establish the concept of sexual harassment in Title VII law. Like other concepts that have mobilized social action, ${ }^{47}$ the concept of sexual harassment took root in the context of litigation designed to achieve reform.

\section{Early Radical Feminist Ideas}

In the late 1960s and early 1970s, as the women's movement gained momentum, two strands coalesced to forge a focus on sexual harassment in the workplace. First, strong elements of the movement concentrated on helping women achieve economic independence by opening work and training

as sexual objects, as body parts, it pretty much sends a message to the employees,' said . . . the only female machinist at the plant. 'What I want Stroh's to do is to take a look at that and understand that they'ro giving a big stamp of approval."').

45. Bikini Ad Prompts a Sexual Harassment Suit, N.Y. TIMES, Nov. 9, 1991, at All. For storics with similar headlines, see Stuart Elliott, Suit over Sex in Beer Ads Comes as Genre Changes, N.Y. TIMES, Nov. 12, 1991, at D22; Doug Grow, Stroh's and Its Ads Square Off Against an Angry Young Lawyer, STAR TRIB. (Minneapolis), Nov. 10, 1991, at 3B; Paul McEnroe, Women Cite Sexy Ads in Harassment Suit Against Stroh's, STAR TRIB. (Minneapolis), Nov. 8, 1991, at 1A; Martha T. Moore, Taste Test: Debate Brews over Selling Beer with Sex, USA TODAY, Nov. 15, 1991, at 1B; and George Will, Misguided Suit Targets Swedish Bikini Team, ST. LouIS POST-DISPATCH, Dec. 2, 1991, at 3B.

46. A complete account of the origins of the paradigm would map the more remote historical antecedents of the phenomena discussed in this Article. The cultural-radical feminist traditions discussed in the next subsection, for example, might be traced to the social purity wing of the 19th-century women's movement. For a description of the views of sexuality articulated within that movement, see Ellen Carol DuBois \& Linda Gordon, Seeking Ecstasy on the Battlefield: Danger and Pleasure in Nineteenth-Century Feminist Sexual Thought, in PLEASURE AND Danger: Exploring Female SeXuality 31 (Carol S. Vance ed., 1984). In addition, a more comprehensive historical account might trace the emergence of widespread cultural fears of the homosexual predator. Cf. George Chauncey, Jr., The Postwar Sex Crime Panic, in TRUE STORIES FROM THE AMERICAN PAST 160 (William Graebner ed., 1993) (showing how the post-World War I panic about sex crime contributed to a new, more ominous stereotype of homosexual men as criminals and child molesters). Even though Title VII harassment law has been most centrally concerned with men's sexual violation of women, the specter of men's sexual pursuit of other men has haunted the legal conception of harassment from the very beginning. See infra note 93.

47. See, for example, MICHAEL MCCANN, RIGHTS AT WORK: PAY EQUITY REFORM AND THE POLITICS OF LEGAL MOBILIZATION (1994), an excellent study of the mobilization of law in the pay equity movement. 
opportunities that had formerly been closed. ${ }^{48}$ Although women of diverse political perspectives embraced this goal, ${ }^{49}$ the women's rights wing of the movement turned to legal reform as a central strategy. The National Organization for Women (NOW) was formed in 1966 to bring public pressure on the EEOC to enforce Title VII's prohibition against sex discrimination in employment. $^{50}$ NOW members filed suits challenging sex-segregated advertising, lobbied the Department of Labor to include women in its affirmative action guidelines for federal contractors, persuaded the Federal Communications Commission to open up opportunities for women in broadcasting, and helped secure the passage of the 1972 amendments to Title VII to allow the EEOC to fight discrimination more effectively. ${ }^{\text {sI }}$ Other feminists launched their own Title VII lawsuits, including across-the-board challenges to systems of sex segregation at work. ${ }^{52}$

At the same time, radicals within the women's liberation movement were beginning to focus on gender-related problems in the spheres of private life-including sexual relations. ${ }^{53}$ Although radical feminism was the creation

48. See Jane Sherron De Hart, The New Feminism and the Dynamics of Social Change, in WOMEN'S AMERICA: REFOCUSING THE PAST 493, 510 (Linda K. Kerber \& Jane Sherron De Hart ods., 3d ed. 1991) (The fact that so many women continue to rely on men not only for financial suppon but also for social status and even self-esteem, feminists argue[d], deprives such women of the economic and psychological freedom to determine their own lives, to make real choices, to be judged as individuals on the basis of their own merit and accomplishments, not those of fathers or husbands."); id. at 500-07 (describing the role of women's growing presence in the workforce in creating conditions for modern feminism, and describing feminist efforts to make work and training opportunities more widely available to women).

49. In addition to mainstream women's rights advocates, more militant feminists from traditions concerned about poverty and economic justice also focused on the sex-based stratification of work as a key element in women's oppression. See id. at 510 ("Ferninists whose socialism was forged in the New Left of the 1960s [saw] oppression as the inevitable result of a capitalist system that keeps women cconomically dependent on men."); see also Heidi Harmann, Capiralism. Patriarchy and Job Segregation by Sex, 1 SIGNS 206 (1976) (arguing that the sexual division of labor is the most fundamental mechanism for reproducing women's oppression).

50. The EEOC was slow to begin enforcing Title VIl's prohibition against sex discrimination in employment. See De Hart, supra note 48, at 506. Although a number of sources have characterized the prohibition against sex discrimination as a joke-a last-ditch effon by opponents to defeal the legislation, see, e.g., Developments in the Law-Employment Discrimination and Tille VII of the Civil Righ's Act of 1964, 84 HARV. L. REV. 1109, 1167 (1971)-some scholars have challenged that view, see. e.8.. Michael Evan Gold, A Tale of Two Amendments: The Reasons Congress Added Sex so Tille VII and Their Implication for the Issue of Comparable Worth, 19 DUQ. L. REV. 453, $457-69$ (1981) (anguing that, even if the members of Congress who introduced the amendment adding sex did so in an effort to defeat the bill. the majority of Congress did not have that motivation when it approved the amendment).

51. See De Hart, supra note 48, at 506 (referring to Equal Employment Opportunity Act of 1972. Pub. L. No. 92-261, 86 Stat. 103 (codified as amended at 42 U.S.C. $\$ 20000(j)(1994)$ ).

52. For examples of early, across-the-board challenges, see Kyriazi : Westem Electric Co., $461 \mathrm{~F}$. Supp. 894 (D.NJ. 1978); and Werzel v. Liberty Murual Insurance Co., 372 F. Supp. 1146, 1149 (W.D. Pa. 1974), aff'd, 511 F.2d 199 (3d Cir. 1975), vacated on other grounds, 424 U.S. 737 (1976). Both cases are discussed in BARBARA R. BERGMANN. THE ECONOMIC EMERGENCE OF WOMEN 106-10 (1986).

53. See, e.g., John D'EMILIo \& Estelle B. FreEdMan, INTIMATE Matters: A history of SEXUALITY IN AMERICA 308 (1988) ("Women's liberation... analyzed the erotic as a vehicle for domination which, in complex ways, kept [women] in a subordinate place in socicty."): ALCEE ECHOLS. DARING TO BE BAD: RADICAL FEMINISM IN AMERICA 1967-1975, at 3-4 (1989) ("Radical feminisis articulated the earliest and most provocative critiques of the family, marriage, love, normative heterosexuality, and rape."). 
of many groups with varying views, most agreed that heterosexual sexual relations were fraught with power dynamics that subordinated women to patriarchal norms. ${ }^{54}$ Beneath the unifying umbrella of a challenge to prevailing sexual politics, there were tensions in early radical feminist thought. Some saw heterosexual sexuality as redeemable, even potentially empowering, if purged of sexism; others saw it as intrinsically dominated by men. ${ }^{5 s}$ Radical feminists also differed on men's motivations: They debated whether "men defend[ed] their power in order to get services [including sex] from women," or "demanded services from women in order to affirm their sense of power." 56 These controversies translated into competing characterizations of rape: Some feminists asserted that "rape is violence-not sex," while others challenged the boundary between rape and "normal" male sexual aggression. ${ }^{57}$

As Ellen Willis has shown, these tensions gave way in the mid-1970s to a new strand of cultural-radical feminism. ${ }^{58}$ According to this emergent analysis, sexual desire and domination were inextricably linked in the institution of heterosexuality-which was central to male superiority. According to this view, women were subordinate to men and heterosexual sexual relations were the primary mechanism of enforcing women's oppression: "[A]ll sexist behavior [wa]s an extension of the paradigmatic act of rape. From this standpoint sexual violence was the essence and purpose of male dominance, the paradigmatic 'male value,' and therefore feminism's central concern." 59

Given early feminists' dual focus on sexuality and work, it is not surprising that feminist activists began to highlight women's sexual exploitation on the job. In 1975, a group of activists in Ithaca, New York, formed Working Women United (WWU). They held the first "Speak-Out on

54. My analysis here draws on ELLEN WILLIS, Radical Feminism and Feminist Radicalism, in No MORE NICE GIRLS: COUNTERCULTURAL. ESSAYS 117 (1992). For other descriptions of the early radical feminist critique of heterosexual sexual relations, see D'EMILIO \& FREEDMAN, supra note 53, at 308-14; and ECHOLS, supra note 53, passim.

55. See WiLLIS, supra note 54, at 130-32 (comparing the views of the Redstockings and the Ferninists). According to Willis,

[Redstockings] took for granted women's desire for genital sexual pleasure . . . and focused

[their] critique on the ways men repressed and frustrated women sexually. . . . [They] rejected sexual separatism as a political strategy, on materialist grounds-that simply refusing to be with men was impractical and unappealing for most women, and in itself did nothing to challenge male power.

Id. at 132. The Feminists, by contrast, "assumed that the primary institutions of women's oppression[including] . . . heterosexuality - were entirely defined by sexism, that their sole purpose was to perpetuate the 'sex-role system." Id. at 130. They "were the first radical feminist group to suggest that living or sleeping with men was collaborating with the system." Id. at 131. Their manifesto suggested "that any special interest in or desire for genital sex, heterosexual or otherwise, was a function of sexism." Id. at 132.

56. Id. at 133 (describing differences in philosophy between earlier radical feminist groups and the New York Radical Feminists).

57. Id. at 143.

58. See id. at 143-44.

59. Id. at 144. 
Sexual Harassment," and organized the first survey devoted solely to the issue. $^{60}$ The group clearly conceptualized harassment in terms of sexual advances. An early article by one of the group's founders, Dierdre Silverman, defined sexual harassment as "the treatment of women workers as sexual objects." Al According to Silverman, harassment exists "when job retention, raises or promotions depend on tolerating, or submitting to, unwanted sexual advances," the form of which "varies from clearly suggestive looks and/or remarks, to mild physical encounters (pinching, kissing, etc.) to outright sexual assault." ${ }^{, 62}$

Lin Farley, another of WWU's founders, adopted a similar conception in her book, Sexual Shakedown. ${ }^{63}$ The book begins with a description of two instances of sexual harassment. ${ }^{64}$ The first involves a dentist who repeatedly made sexual advances toward his receptionist and eventually tried to rape her, all the while telling her that this was why he had hired her and that it was only a matter of time before he would have her. ${ }^{65}$ The second involves a restaurant manager who tried to extort sex from teenage girls who applied for jobs. ${ }^{60}$ Although Farley's book hinted at a broader conceptualization by defining harassment as "unsolicited nonreciprocal male behavior that asserts a woman's sex role over her function as worker," ${ }^{\text {"7 }}$ subsequent passages defined the content of the female role exclusively in sexual terms. Harassment, Farley explained, can be "any or all of the following: staring at, commenting upon, or touching a woman's body; requests for acquiescence in sexual behavior; repeated nonreciprocated propositions for dates; demands for sexual intercourse; and rape." ${ }^{.68}$ Just as sexual advances lay at the core of sexual harassment, sexual harassment lay at the core of women's oppression. Farley's colleague Silverman argued that "the paradigm for interactions between men and women in our society is that of the prostitute and her customer." these early feminists, sexual harassment was top-down and male-female.

At the same time that feminist activists were articulating this view, however, there were other commentators who might have laid a foundation for conceptualizing women's harassment on the job in more encompassing terms.

60. See Silverman, supra note 2 , at 15.

61. Id. See, in addition, the definition adopted by the Alliance Agunst Sexual Cocrcion, an anti-harassment group founded by women in Boston who had been active in rape crists work: "Sexual harassment is any unwanted sexual attention a woman experiences on the job, ranging from leenng. pinching, patting, verbal comments, and subtle pressure for sexual acuvity. 10 attempled rape and mpe." The Alliance against Sexual Coercion, Fighting Sexual Harassmeit: an advocacy handbook 9 (1981).

62. Silverman, supra note 2, at 15.

63. Lin Farley, Sexual Shakedown: The Sexual harassatent of women on the Job (1978).

64. See id at 3-11.

65. See id. at 3.

66. See id. at 4-9.

67. Id. at 14-15.

68. Id. at 15 .

69. Silverman, supra note 2 , at 15. 
Carroll Brodsky's book, The Harassed Worker, ${ }^{70}$ for example, was one of the first sources to use the term "sexual harassment."71 Brodsky was a psychiatrist with a doctorate in anthropology who founded a work clinic at the University of California School of Medicine. He based his analysis on more than a thousand cases in which workers sought unemployment compensation on the ground that harassment had left them unable to work. ${ }^{72}$ Rather than defining harassment as a form of sexual exploitation, Brodsky defined the problem in broad, nonsexualized terms: "Harassment behavior involves repeated and persistent attempts ... to torment, wear down, frustrate, or get a reaction from another. It is treatment that persistently provokes, pressures, frightens, intimidates, or otherwise discomforts another person." ${ }^{.33} \mathrm{He}$ saw harassment as a means of competing for material resources and for the respect accorded those who "have it made": "Harassment is a mechanism for achieving exclusion and protection of privilege in situations where there are no formal mechanisms available." 74 In Brodsky's conception, harassment takes different forms, which vary with the occupational setting and with the peculiar vulnerability of those who have been targeted for victimhood; it includes teasing, joking and horseplay, scapegoating, name-calling, physical abuse, social isolation and exclusion, stepping up work pressures, and sexual harassment. $^{75}$

To Brodsky, the term "sexual harassment" itself referred not only to sexual advances, but to all uses of sexuality as a way of tormenting those who felt "discomfort about discussing sex or relating sexually."76 Indeed, sexual harassment by his account included men teasing other men about sexual potency or interest. ${ }^{77}$ As this example makes clear, Brodsky did not see sexual harassment as rooted in sexual desire or a need for sexual domination, ${ }^{78}$ but rather in the same motives as other nonsexual forms of harassment. In Brodsky's conception, harassment could be directed not only top-down, from supervisor to subordinate, but also horizontally, from peer to peer, and even bottom-up, from subordinate to boss ${ }^{79}$-because competition for privilege occurs in all these directions.

70. CARroll M. Brodsky, The Harassed Worker (1976).

71. Id. at 27-28.

72. See id. at vii, xi-xii.

73. Id. at 2 .

74. Id. at 4.

75. See id. at 2-3.

76. Id. at 28 .

77. See id.

78. See id. at 27 (observing that in most cases it appeared that "the male aggressor did not actually wish to have sexual relations, nor even an extended social contact, with his female target" and that "[i]ndeed, one often suspected that he chose [his] victim precisely because he knew she would never agree to his suggestions").

79. See id. at $48-59$. 
Although there were legal parallels to racial harassment that would have justified broad conceptualization of sex-based harassment in Brodsky's terms, ${ }^{80}$ early feminist ideas and emerging Title VII case law worked together to inspire lawyers and activists to articulate the sexual desire-dominance paradigm. Early feminists were unified about the need to expose and hold men accountable for the intimate violations that for too long had been rationalized as beyond reach as part of the private sphere. ${ }^{81}$ They founded organizations that provided research and support, which empowered lawyers to initiate litigation challenging workplace harassment. ${ }^{82}$ Most of the earliest Title VII cases challenging on-the-job harassment involved precisely the sort of topdown, supervisor-subordinate, male-female sexual extortion envisioned by feminist radicals. Both the facts of these cases and the need to refute judges' reasoning contributed toward shaping the understanding of sexual harassment exhibited in the sexual desire-dominance paradigm.

\section{Early Quid Pro Quo Harassment Cases}

Women lost some of the first Title VII cases challenging harassment. ${ }^{83}$ These cases involved the by-now-familiar fact pattern: Female plaintiffs complained that they had been fired or mistreated for refusing their male superiors' sexual advances. Although there were a few doctrinal twists, early courts tended to reject the plaintiffs' claims by reasoning that the women's adverse treatment occurred because of their refusal to engage in sexual affairs with their supervisors and not "because of sex" within the meaning of the statute. ${ }^{84}$ This reasoning reflected the view of sexual relations as a private

80. The first case to recognize a cause of action for a race-based hostile work environment established a broad definition of the types of conduct that might comprise an illegal hostile work environment. See Rogers v. EEOC, 454 F.2d 234 (5th Cir. 1971); see also infra text accompanying notes 143-144.

81. See D'EMILIO \& FREEDMAN, supra note 53, at 311-14: ECHOLS, supra note 53. at 200-02; JEFFREY WEEKS, SEXUALITY AND ITS DISCONTENTS 255-56 (1985).

82. See, e.g., Elvia R. Arriola, "What's the Big Deal?": Women in the New Yort Cing Construction Industry and Sexual Harassment Law, 1970-1985, 22 CoLUM. HUM. RTS. L REV. 21. 36 (1990) (arguing that the Working Women's Institute "empowered feminist lawyers 10 begin the process of codifying the political argument that unwanted sexual advances towards working women constituted abuse, harassment and employment discrimination"); Enid Nemy, Center Helps Fight Serual Harassment, N.Y. TIMES, Mar. 3, 1980, at D7 (announcing the opening of the National Sexual Harassment Legal Backup Center in New York City to prepare amicus briefs, to assist lawyers, and to seck an extension of legal protection); $c$. Silverman, supra note 2, at 23 (declaring an intent to open the WWU Institute to do "research in the area of sexual harassment as well as education and litigation nocessary to bring the problem to public consciousness").

83. For descriptions of the lower court decisions in these early cases, sec CATIARINE A. MACKINNON, SEXUAL HaRassment OF WORKIng WOMEN: A CASE OF SEX DISCRIMINation 59-77 (1979): Arriola, supra note 82, at 40-44; Jill Laurie Goodman. Sexual Harassment: Some Observations on the Distance Traveled and the Distance Yet To Go, 10 CAP. U. L. REV. 445, 459-65 (1981); and Kerri Weisel, Comment, Title VII: Legal Protection Against Sexual Harassmens, 53 W ASH. L. REV. 123, 124-29, 138-41 (1977).

84. See, e.g., Tomkins v. Public Serv. Elec. \& Gas Co., 422 F. Supp. S53. 556 (D.NJ. 1976) (concluding that a male supervisor's sexual advances on a female subordinate were not discrimination based on sex within the meaning of Title VII and stating that even though "(i)n this instance the supervisor was 
phenomenon not amenable to public scrutiny that feminists were intent on repudiating. By treating sexual advances as a purely personal matter beyond the scope of legal inquiry, courts refused to acknowledge that the sphere of sexuality can be infused with gender discrimination-in other words, that sexual relations can be an arena in which people are disadvantaged because of their identities as women or men.

Drawing on feminist ideas, lawyers responded to this reasoning with arguments explaining why unwanted sexual advances should be seen as discrimination because of sex. In one of the earliest law review pieces on sex-based harassment, feminist Kerri Weisel argued that sexual harassment was due to gender "based either on the presumption that the supervisor is heterosexual, or [on] the belief that sexual harassment reflects a general stereotyped view of women, or both." ${ }^{35}$ Weisel first argued that the law should presume that a male supervisor who harasses a female employee is heterosexual and that the supervisor's heterosexuality supplies an inference that the harassment is gender-based. ${ }^{86}$ This argument assumed that harassment consists of sexual advances driven by sexual desire. Otherwise, there would be no reason why a heterosexual man would be any more likely than a homosexual or bisexual man to harass a woman worker. If harassment were a means of competing for privilege, as in Brodsky's model, gay or bisexual men would be just as likely as heterosexual men to harass their female coworkers.

Weisel's second argument confirmed this desire-based interpretation. She argued that the law should presume that a supervisor's harassment amounts to illegal stereotyping of women as sexual objects, unless the supervisor shows that he is bisexual. ${ }^{87}$ Under this argument, a heterosexual male supervisor's sexual advances toward a woman would be based on gender because he would not have made such advances toward-and thereby stereotyped as an object of sexual desire-a male employee. Similarly, a homosexual male supervisor's sexual advances toward a man would be based on gender because the supervisor would not have made such advances toward-and sexually stereotyped-a female employee. Weisel's tying of the supervisor's presumed heterosexuality to the presumed illegal stereotyping reveals that, in her

male and the employee was female, [the] gender lines might as easily have been reversed, or even not crossed at all"), rev'd, 568 F.2d 1044 (3d Cir. 1977); Barnes v. Train, 13 Fair Empl. Prac. Cas. (BNA) 123, 124 (D.D.C. 1974) (concluding that the "substance of plaintiff's complaint," that her position was abolished when she refused to have sexual relations with her supervisor, "is that she was discriminated against, not because she was a woman, but because she refused to engage in a sexual affair with her supervisor"), rev'd sub nom. Bames v. Costle, 561 F.2d 983 (D.C. Cir. 1977); see also Come v. Bausch \& Lomb. Inc., 390 F. Supp. 161, 163 (D. Ariz. 1975) (characterizing the verbal and physical sexual advances of plaintiffs' supervisors as "nothing more than a personal proclivity, peculiarity or mannerism" and an attempt at "satisfying a personal urge"), vacated, 562 F.2d 55 (9th Cir. 1977).

85. Weisel, supra note 83 , at 133 .

86. See id. at 133-35.

87. See id. at 136. 
analysis, heterosexual male sexual desire was closely aligned with male domination. Thus, even though her analysis included the possibility of harassment by a gay supervisor, what she really had in mind was harassment of a woman by a heterosexual male supervisor. ${ }^{88}$ Like most feminists of the day, Weisel assumed that heterosexual male sexual advances were the core of sexual harassment, that such advances were driven by sexual motivations, and that such motivations supplied an inference of gender discrimination.

This line of reasoning was soon adopted by the courts. Barnes $v$. Costle $e^{89}$ was one of the first cases to adopt it. Paulette Barnes was stripped of her job because she refused her supervisor's sexual advances. The district cour rejected her claim and held that she was discriminated against, "not because she was a woman, but because she refused to engage in a sexual affair with her supervisor." 90 The Court of Appeals for the District of Columbia Circuit reversed. Writing for the court, Judge Robinson concluded that Barnes's firing had occurred "because of sex" within the meaning of Title VII because Barnes's "job was conditioned upon submission to sexual relations-an exaction which the supervisor would not have sought from any male."91

In a puzzling passage, Judge Robinson claimed that his conclusion "stemmed not from the fact that what [her boss] demanded was sexual activity - which of itself is immaterial," but solely from the fact that "but for her gender she would not have been opportuned." 92 Yet, Robinson proceeded to justify his conclusion with the observation that "there is no suggestion that [the] allegedly amorous supervisor is other than heterosexual." ${ }^{\text {93 }}$ Thus, his

88. Like most feminists of that time, Weisel assumed that in most sttuatsons, sexual destre and sexual stereotyping converge. She showed unusual foresight and sophistucation, however, in acknowledging that the two do not always coexist. In a footnote, she stated that bisexuality would not be an irrebuttable defense: "[A]lthough a bisexual supervisor may not have a sexual preference for women, he might stull harass only women in response to the prevailing stereotype." $/ d_{\mathrm{x}}$ at $137 \mathrm{n.63.}$

89. 561 F.2d 983 (D.C. Cir. 1977).

90. Barnes v. Train, 13 Fair Emp. Prac. Cas. (BNA) 123. 124 (D.D.C. 1974), rev'd sub nom. Bames v. Costle, 561 F.2d 983 (D.C. Cir. 1977).

91. Barmes, 561 F.2d at 989.

92. Id. at $989 \mathrm{n} .49$ (emphasis added).

93. Id. That Judge Robinson's conclusion was grounded in sexual desire is supported by an additional passage in which he adopted the analysis proposed by Weisel. In this passage. Robinson stated that sexual advances made by a homosexual supervisor on a same-sex subordinate would constitute discrimination "because of sex" within the meaning of Title VII-because the supervisor would not have directed such advances toward a person of the opposite sex-while advances made by a bisexual supervisor upon men and women alike would not. See id. at 990 n.55.

A number of commentators have criticized the coun for suggesung that a bisexual supervisor who directs sexual advances toward both men and women would escape Title VII Irability for such sexual exploitation. See, e.g., Sandra Levitsky, Note, Foomore 55: Closing the "Bisexual Defense" Loophole in Title VII Sexual Harassment Cases, 80 MiNN. L. REv. 1013 (1996); Deborah McFarland. Note, Beyond Sex Discrimination: A Proposal for Federal Sexual Harassment Lugation, 65 FORDHAM L. REV. 493, 520 (1996). My criticism is different. Rather than criticizing the coun for permutting sexual overures by a bisexual supervisor to go unpunished, my analysis suggests that the focus on harassment as sexual overtures is the source of the problem. Once such a focus is abandoned and harassment is understood more broadly to include any kind of conduct directed at someone because of gender, it becomes elear that the sexual orientation of the harasser is irrelevant. Indeed, if harassment is grounded in a dnve to mauntaun favored lines of work as masculine, there is little reason to suppose that heterosexual men would be any more likely 
analysis came full circle: That the conduct was sexual in nature was irrelevant, he claimed, because the salient inquiry was whether it was directed toward one sex but not another. Yet, the only basis for inferring that the conduct would not have been directed at a male employee was precisely the fact that the conduct consisted of sexual advances, advances which the court coded through a matrix of heterosexual desire. Had Barnes's supervisor yelled at her or insulted her intelligence, the court would have had a much more difficult, if not impossible, time concluding that such conduct would not have been directed at a man. Thus, in spite of the court's own effort to ground the decision in analysis based on gender rather than on the sexual content of the conduct, the decision equated the pursuit of heterosexual sexual relations with gender discrimination.

Barnes ushered in the new legal paradigm. Its reasoning formed the basis for recognizing quid pro quo harassment-a supervisor's attempt to condition employment benefits on sexual favors-as a violation of Title VII. Within three years, at least two other courts of appeals had followed its reasoning. ${ }^{94}$ In addition, the EEOC issued a comprehensive set of guidelines on sex-based harassment. 95 These guidelines not only prohibited the quid pro quo harassment involved in Barnes, but also approved the notion of hostile work environment harassment. ${ }^{96}$

These trends established a paradigm for understanding workplace harassment. To the extent that this paradigm acknowledged that gender discrimination can take the form of sexual advances and exploitation, it represented progress. But to the extent that it went beyond this recognition to define sexual advances and gender-based harassment as coextensive, it portended problems. The EEOC guidelines, for example, could be read to limit the universe of gender-based harassment to sexual conduct. According to the guidelines, harassment involved: "unwelcome sexual advances, requests for sexual favors, or other verbal or physical conduct of a sexual nature." Published around the same time as the EEOC guidelines, Catharine

than men of any other sexual orientation to engage in such harassment.

94. See Miller v. Bank of Am., 600 F.2d 211 (9th Cir. 1979); Tomkins v. Public Serv. Elec. \& Gas Co., 568 F.2d 1044 (3d Cir. 1977).

95. See EEOC Guidelines on Discrimination Because of Sex, 62 Fed. Reg. 63,622 (1980) (codified at 29 C.F.R. \& 1604.11 (1997)).

96. The guidelines define actionable harassment as follows:

Unwelcome sexual advances, requests for sexual favors, and other verbal or physical conduct of a sexual nature... when (1) submission to such conduct is made either explicitly or implicitly a term or condition of an individual's employment, (2) submission to or rejection of such conduct by an individual is used as the basis for employment decisions affecting such individual, or (3) such conduct has the purpose or effect of unreasonably interfering with an individual's work performance or creating an intimidating, hostile, or offensive working environment.

29 C.F.R. $\$ 1604.11$ (a). On the two different types of sex-based harassment, see supra note 7.

97. 29 C.F.R. \& 1604.11(a) (emphasis added). Indeed, as I discuss throughout the following pages, the guidelines were so read. 
MacKinnon's book on sexual harassment law further conflated sexual exploitation and gender inequality. ${ }^{98}$ Articulating the new line within culturalradical feminism, MacKinnon argued that harassment is problematic precisely because it is sexual in nature-and because heterosexual sexual relations are the primary mechanism through which male dominance and female subordination are maintained. 99 In MacKinnon's words, "A major substantive element in the social meaning of masculinity, what men learn makes them 'a man,' is sexual conquest of women; in turn, women's femininity is defined in terms of acquiescence to male sexual advances." 100 To MacKinnon, gender and sexuality were coextensive: The inequality between men and women was constructed primarily through sexual relations, and sexuality had no significant existence outside gender hierarchy. ${ }^{101}$

With these developments, the sexual desire-dominance paradigm was firmly in place. Forged of noble intentions by feminists and sympathetic legal reformers, the paradigm would have serious consequences for the development of Title VII harassment law-and for the women and men who needed the law's protection from forms of harassment that did not fit easily within its parameters.

98. See MaCKinNon, supra note 83.

99. See id passim; see also KathleEN BARRY. FeMIALE SEXUAL SLAverry 164-65 (1979) ("Sex-is-power is the foundation of patriarchy.... Institutionalized sexism and misogyny-from discrimination in employment, to exploitation through the welfare system. to dehumanization in pomography-stem from the primary sexual domination of women in one-10-one situations."): ANDREA DWORKIN, INTERCOURSE 126 (1987) ("Intereourse as an act often expresses the power men have over women. Without being what the society recognizes as rape, it is what the socjety, when forced to admit it, recognizes as dominance.").

100. MACKINNON, supra note 83, at 178.

101. For a passage expressing this view, consider, for example. MacKinnon's critique of the feminist proposition that rape is violence, not sex:

The radical distinction between rape and intercourso-rape is violence. intercourse is sexuality-is both the most basic and the least examined premise of this approach.

... But is ordinary sexuality, under conditions of gender inequality, to be presumed healthy? What if inequality is built into the social conceptions of male and female sexuality. of masculinity and femininity, of sexiness and helerosexual attractiveness? Incidents of sexual harassment suggest that male sexual desire itself may be aroused by female vulnerability. ...

....

Analysis of sexuality must not be severed and abstracted from analysis of gender. . . If sexuality is set apart from gender, it will be a law unto itself.

Id. at 218-21. This analysis foreshadowed the more trenchant statement in MacKinnon's later essay:

Gender socialization is the process through which women come to identify themselves as sexual beings, as beings that exist for men. ... According to this revision. one "becomes a woman"-acquires and identifies with the status of female-not so much through physical maturation or inculcation into appropriate role behavior as through the experience of sexuality. ... .

Women and men are divided by gender, made into the sexes as we know them, by the social requirements of heterosexuality, which institutionalizes male sexual domunance and female sexual submission. If this is true, sexuality is the linchpin of sexual inequality.

Catharine A. MacKinnon, Feminism, Marxism, Method and the State: An Agenda for Theory, 7 Stans 515. 531-33 (1982). 


\section{An Illustration from the Case Law}

The Seventh Circuit's decision in King v. Board of Regents of the University of Wisconsin System ${ }^{102}$ provides an illustration of how courts have utilized the prevailing paradigm to limit Title VII law. Katherine King was an assistant professor of occupational therapy who was denied tenure at the University of Wisconsin-Milwaukee (UWM). The very first semester King began teaching, her assistant dean, Steven Sonstein, "began making suggestive innuendoes as well as leering at her in a sexually suggestive fashion." ${ }^{103}$ As the semester wore on, he "became progressively more bold and offensive with respect to his sexual behavior toward King. He repeatedly leered at King and would from time to time touch her, rub up against her, place objects between her legs, make suggestive remarks and comment upon various parts of her body." 104 Sonstein's behavior, which "was blatant enough for other faculty members to notice and comment upon," ${ }^{105}$ culminated in a sexual assault. At the department's annual Christmas party, Sonstein followed King into a bathroom, told her he "had to have her," and forcibly kissed and fondled her. ${ }^{106}$ After King "discussed the problem with Sonstein," he falsely accused her of using UWM photocopying equipment for personal use, a serious charge of which King was eventually cleared. ${ }^{107}$ She later filed a formal complaint of sexual harassment against Sonstein within the university; as part of the settlement, Sonstein was to abstain from voting on matters relating to King's appointment. ${ }^{108}$

King also alleged that the director of the occupational therapy program, Franklin Stein, had contributed to the hostile work environment at UWM. Stein's hostility, however, took a nonsexual form: Over the course of a sixyear period, he created conditions that undermined her ability to do her job and made it difficult for her to get tenure. According to King, Stein gave her a heavier workload and a lower salary; he subjected her to an unprecedented number of teaching evaluations; he gave her poor appraisals; he mistreated her during faculty meetings; he interfered with the tenure process; and he attempted to limit her research time and increase her teaching load. At trial, "King supported these allegations with a variety of incidents occurring over the six year period she was with UWM." 109 For example, Stein sought to defund

102. 898 F.2d 533 (7th Cir. 1990). For an article on King that places the case in the context of other sex discrimination cases against the University of Wisconsin-Milwaukee, see Scott Kerr, The System: While UWM Pays a \$300,000 Settlement, Officials Say 'the System' Is Working Fine; Those Who Complain Say It's the Cause of the Problems, SHEPARD EXPRESS (Milwaukee), Dec. 13, 1990, at 1.

103. King, 898 F.2d at 534 .

104. Id. at 534-35.

105. Id. at 535 .

106. Id.

107. Id.

108. See id.

109. Id. 
a grant she had received to allow her to buy time for research by hiring a substitute to teach her courses. Subsequently, Stein insisted on presenting King's file to the tenure committee over King's objection that Stein would fail to present it in a favorable light. King's concern appears to have been well-founded, for Stein voted against her on the tenure committee. The committee found that she had failed to meet the department's tenure standards, "whether it was because of discriminatory treatment or her own failings."110

Although a jury held Stein, Sonstein, and UWM liable for engaging in discriminatory treatment of King and creating a hostile work environment based on her sex, ${ }^{\text {"I }}$ the district court overturned the jury's verdict on all but the harassment claim against Sonstein. The Seventh Circuit affirmed. The cour of appeals distinguished Sonstein's sexual misconduct from the other nonsexual mistreatment directed at King. For purposes of King's hostile work environment harassment claim, the court considered only the sexual conduct: "Sonstein repeatedly verbally assaulted King, fondled her, and at one point, physically attacked her. His advances were unwelcome and he was so told." 112 By contrast, the court analyzed the nonsexual hostility directed at King-including Stein's imposition of "workload and salary disparities, lack of guidance, and unequal treatment during the tenure/contract renewal process," 113 and Sonstein's false accusation of personal photocopying and interference with King's ability to satisfy the tenure requirements-not under the hostile work environment claim, but under a separate discriminatory treatment claim. ${ }^{14}$

According to the court, the difference between disparate treatment and hostile work environment harassment is that whereas "claims of disparate treatment must affect the terms or conditions of employment," work environment claim, "a loss of a tangible job benefit is not necessary since the harassment itself affects the terms or conditions of employment" (so

110. Id. at 536.

111. The Seventh Cincuit began its opinion by notıng that "[a] jury issued a special verdict.... finding discrimination, harassment, and retaliation by three employees of UWM and vicanous liability of UWM." Id. at 534. Later, in its recitation of the facts, the court suggesied that the jury perthaps did not find Stein liable for sexual harassment: "The jury found, in a spocial verdict, that Sonsiein subjected her to sexual harassment, sexual discrimination, and retaliation and that Stein subjected her to sexual discrimination, retaliation, and deprivation of a property interest without due process." Id. at 536 . In the beginning of its legal analysis, however, the cour made clear that, "[o]n appeal. Kıng alleges sexual discrimination based on disparate treatment, environmental sexual harussment, retaltation. . . and deprivation of a propenty interest without due process. She makes these claums against both Stetn and Sonstein under both Title VII and section 1983." /d. (emphasis added). Thus. regardless of what the jury may have found with respect to the hostile work environment harassment clam aganst Stein, 11 seems that the court considered this claim to have been part of the appeal (though it did not specify exactly how the claim was raised).

112. Id. at 538 .

113. Id. at 537.

114. See id. at 541.

115. Id. at 537. 
long as it is sufficiently severe or pervasive). ${ }^{116}$ Yet this doctrinal distinction provided no reasoned basis for distinguishing the sexual conduct from the nonsexual conduct. Neither class of conduct-from Sonstein's sexual assault on King to Stein's efforts to limit her research time-in and of itself effected a formal job loss like the decision to deny King tenure. Moreover, King alleged that both sets of conduct created conditions that undermined her status and performance on the job and made it difficult for her to satisfy the tenure requirements. The court simply took for granted that hostile work environment harassment refers to "sexual" harassment, which the court envisioned as sexual advances. As a result, the court had little difficulty concluding that Sonstein's sexual overtures constituted hostile work environment harassment that violated Title VII. ${ }^{117}$

The King court made explicit the implicit premise of Barnes $v$. Costle and other early quid pro quo harassment cases: It is the presence of heterosexual desire that indicates an allegedly harassing action was taken "because of sex" within the meaning of the law. Sonstein argued that "his actions were merely the result of his desire for King as an individual and, therefore, were not sex-based harassment." 118 Although the Seventh Circuit might have responded to this argument in any number of ways, it responded as the D.C. Circuit had in Barnes, by defining sexual desire as the sine qua non of gender-based harassment:

This argument ... misses the point. Sonstein wanted to have an affair, a liaison, illicit sex, a forbidden relationship. His actions are not consistent with platonic love. His actions were based on her gender and motivated by his libido.

... Sonstein's sexual desire does not negate his intent; rather it affirmatively establishes it. ${ }^{119}$

The court's analysis foreshadowed that it would rule against King on her other claims. Once the court had disaggregated the sexual advances from the other offending conduct, it became difficult to envision the discriminatory character of the nonsexual conduct. Even though a jury found in King's favor on her disparate treatment claims, the court of appeals upheld the lower court's grant of judgment notwithstanding the verdict, rejecting the finding that Stein had subjected King to workload and salary disparities based on her gender. The appellate court acknowledged being "troubled" by King's "other, more nebulous" allegations of discriminatory treatment by Stein-such as his limiting her research time and negatively presenting her tenure case-but

116. Id.

117. See id. at $538-39$.

118. Id. at 538 .

119. Id. at 539 . 
concluded that "no term, condition or privilege of employment was affected as a result of these actions"120 because King had failed to prove that any of them "caused her failure to meet the requirements for contract renewal."121 Similarly, even if Sonstein's false accusation that King had engaged in personal photocopying did amount to discrimination, "King did not prove that she lost a job benefit... as a result of this incident." 122 Although King protested that all the discriminatory treatment-taken together-had psychologically and materially disabled her from satisfying the tenure requirements, the court rejected this argument as well. ${ }^{123}$

The court's analysis placed King (and other plaintiffs) in a Catch-22. The concept of a hostile work environment was developed out of an awareness that some actions by supervisors or coworkers can create an atmosphere that undermines "the right to participate in the work place on [an] equal footing," 124 even though these actions may not affect any tangible job benefit. ${ }^{125}$ Many of the nonsexual actions against King fell within this category. Yet, because the court envisioned conduct driven by sexual desire to be the quintessential harassment, it refused to consider the nonsexual actions under a hostile work environment framework. Once it had relegated such actions to a disparate treatment framework, the plaintiff was bound to lose: The court assumed that incidents must affect a tangible job benefit in order for a plaintiff to prevail under a disparate treatment framework, yet it had consigned to that framework incidents that on their face failed to qualify. The only basis the court had for consigning those incidents to a disparate treatment framework was their lack of sexual content.

Had the court considered both the sexual and nonsexual conduct under an integrated framework, it might have seen the truth through King's (and the jury's) eyes. From King's perspective, the assistant dean's sexual advances and his eventual retaliation against King were only some of the many manifestations of the UWM occupational therapy deparment's failure to take women seriously as scholars and equals. Through a variety of actions, both subtle and obvious, King felt she was denied the research support, mentoring, collegiality, and respect that signal a faculty's belief in an assistant professor's promise. Taken together, Sonstein's and Stein's actions communicated to King that she was "different" and not quite good enough. In the end, these actions became a self-fulfilling prophecy: King claimed that they had "caused her to be permanently psychologically disabled, thereby preventing her from fulfilling

120. Id.

121. Id. at 540.

122. Id.

123. See id.

124. Id. at 537 (quoting Scott v. Sears, Rocbuck \& Co., 798 F.2d 210. 213 (7th Cir. 1986)).

125. See Meritor Sav. Bank v. Vinson, 477 U.S. 57.73 (1986); Rogers v. EEOC. 45.4 F.2d 234, 238 (5th Cir. 1971). 
the tenure requirements or obtaining another job elsewhere in academics." By undermining her ability to meet the tenure standards and driving her out of the department, Sonstein's and Stein's actions reinforced the notion that women are less capable intellects who do not belong in their department.

The Seventh Circuit's decision is characteristic of the way in which the federal courts have handled claims like those made by King. Wittingly or unwittingly, judicial embrace of the sexual desire-dominance paradigm has led courts to envision sexual advances as the quintessential harassment. This view, in turn, has led to doctrinal developments that have distorted the law and limited its capacity to address very real forms of gender-based hostility experienced by women at work. I discuss these developments in the next two parts.

\section{The SeXualization of THE Hostile WORK ENVIRONMENT}

To a large extent, the courts have restricted the conception of hostile work environment harassment to male-female sexual advances and other explicitly sexualized actions perceived to be driven by sexual designs. In doing so, courts have created a framework that is underinclusive. By defining the essence of harassment as sexual advances, the paradigm has obscured-and excludedsome of the most pervasive forms of gender hostility experienced on a day-to-day basis by many women (and men) in the workplace. I begin with a description of the influence of the paradigm at the Supreme Court level, and then analyze its development within the lower federal courts. ${ }^{127}$

\section{A. The Supreme Court's Decision in Harris v. Forklift Systems}

In Harris v. Forklift Systems, Inc., ${ }^{128}$ the Supreme Court had an opportunity to expand the legal understanding of hostile work environment harassment. Theresa Harris was the rental manager in a company that sold, leased, and repaired forklift equipment. She was one of only two female managers; the other was the daughter of the company president, Charles Hardy. During Harris's tenure, Hardy subjected her to various treatment undermining her authority as a manager, such as denying her an individual office, a company car, and a car allowance; paying her on a different basis from the other managers; refusing to give her more than a cursory annual review; and forcing her to bring coffee into meetings, which he never asked male managers

126. King, 898 F.2d at 540 .

127. My review of lower federal court cases is comprehensive. I ran searches for all sex-based hostile work environment cases decided since Vinson. I read all the relevant cases decided between Vinson and Harris v. Forklift Systems, Inc., 510 U.S. 17 (1993), and I read a random sample of all the cases decided after Harris.

128. 510 U.S. 17 (1993). 
to do. Hardy made it plain that he considered women inadequate as managers. He frequently denigrated the plaintiff in front of other employees with such remarks as, "You're a woman, what do you know"; "You're a dumb ass woman"; and "We need a man as the rental manager." 129 Hardy made other comments that demeaned Harris as a professional, suggesting that the two of them go to the Holiday Inn to negotiate her raise and intimating that she must have promised sex to a client in order to obtain an account. In addition, Hardy denigrated Harris's managerial role by subjecting her to the same sort of sophomoric, sexually oriented conduct that he directed at lower-level women employees (but not male employees), such as asking her to retrieve coins from his front pocket and making suggestive comments about her clothing. ${ }^{130}$

Despite Hardy's conduct, the district court adopted the magistrate's conclusion that the harassment did not rise to the level of a hostile work environment. ${ }^{131}$ The Sixth Circuit affirmed. Harris's appeal to the Supreme Court emphasized only one aspect of the case: Harris urged that the lower court had erred in requiring her to prove that the harassment had seriously affected her psychological well-being or otherwise caused her psychological injury. The Supreme Court found for Harris, rejecting the lower court's narrow subjective psychological harm requirement and holding that a plaintiff need show only that a reasonable person would have perceived, as Harris did, that the harassment was sufficiently severe or pervasive to create a hostile or abusive work environment. ${ }^{132}$

In focusing on the abstract standards, however, both the Supreme Court and the lawyers failed to address the real problem in the case: the lower court's application of those standards from an overly narrow, sexualized perspective. The magistrate made the classic analytical move made by courts that have adopted the sexual desire-dominance paradigm: disaggregation. He began by parceling out the sexual and nonsexual conduct into separate claims. The nonsexual conduct, such as denying Harris a car, car allowance, office, and annual review, was not considered part of the harassment claim, but was examined under a separate claim of disparate treatment. ${ }^{133}$ For purposes of the hostile work environment claim, the magistrate concluded that only

129. Harris v. Forklift Sys., Inc., 60 Empl. Prac. Dec. (CCH) 9 42,070, at 74,247 (M.D. Tenn. 1991 ). aff'd, 976 F.2d 733 (6th Cir. 1992) (per curiam), rev'd, 510 U.S. 17 (1993).

130. See id. This form of behavior-treating women alike even though some have jobs or roles of much different or higher status-is referred to as "status-leveling" in the relevant literalure. See Rosabetr! MOSS KANTER, MEN AND WOMEN OF THE CORPORATION 231 -32 (rev. od. 1993): cf. Dothand v. Rawlinson, 433 U.S. 321, 343-44 \& n.3 (1977) (Marshall, J.. concurring in part and dissentung in part) (objectıng to the majority's use of attacks by prison inmates on an untrained female clerical worker and a fernale student touring a facility to suppor its proposition that trained female correctuonal officers would be vulnerable to sexual assault by inmates).

131. See Harris, 60 Empl. Prac. Dec. $(\mathrm{CCH})$ at 74,249 .

132. See Harris, 510 U.S. at 22.

133. See Harris, 60 Empl. Prac. Dec. (CCH) at 74,251. This, of course, is the same move made by the Seventh Circuit in King v. Board of Regents of the University of Wisconsin System, 898 F.2d 533 (7th Cir. 1990). See supra Section I.C. 
Hardy's "sexually crude comments" met the EEOC guidelines' definition of actionable harassment. ${ }^{134}$ After limiting his focus to these comments, the magistrate then trivialized them by emphasizing that they did not sufficiently resemble the sexual advances at the core of the sexual desire-dominance paradigm. The Holiday Inn comment, for instance, was a bad joke, "but it was not a sexual proposition." 135 According to the magistrate, Harris's harassment was similar to that of another Sixth Circuit plaintiff who had also been subjected to harassment that was "vulgar and crude," but who lost because "the sexual conduct was not in the form of sexual propositions or physical touching." ${ }^{36}$ Winning cases "involved sexual harassment . . . in the form of requests for sexual relations or actual offensive touching." ${ }^{137}$ Thus, it was the comparison of Harris's mistreatment to an imagined case of sexual advances that led the magistrate and the lower courts to conclude that the mistreatment was not sufficiently injurious to be actionable.

Harris provided a clear opportunity to transcend this unduly restrictive focus. The case presented a chance to expand the concept of hostile work environment harassment to include all conduct that is rooted in gender-based expectations about work roles and to recognize that harassment functions as a way of undermining women's perceived competence as workers. From such a perspective, Charles Hardy's conduct looks like the central sex discrimination that Title VII was intended to dismantle. Taken together, Hardy's conduct-from the "sexual" conduct that reduced Harris to a sexual object as she struggled to fulfill her work role, to the nonsexual but gender-biased conduct that denigrated her capacity to serve as a manager, to the facially gender-neutral conduct that denied her the perks, privileges, and respect she needed to do her job well-had the purpose and effect of undermining Harris's status and authority as a manager on the basis of her sex. These actions fit a classic pattern of harassment often directed at women who try to claim male-dominated work as their own. ${ }^{138}$ Yet, neither the Supreme Court, the Sixth Circuit, the district court, Harris's counsel, ${ }^{139}$ nor most amici curiae $^{140}$ saw the case in these terms or even perceived the magistrate's

134. Harris, 60 Empl. Prac. Dec. $(\mathrm{CCH})$ at 74,249 .

135. Id. at 74,250 .

136. Id. (citing Rabidue v. Osceola Ref. Co., 805 F.2d 611 (6th Cir. 1986)).

137. Id. (emphasis added).

138. See infra Sections IV.A-B.

139. Indeed, Harris's counsel argued from within the sexual desire-dominance paradigm, emphasizing the sexually explicit nature of some of Hardy's conduct. See Petitioner's Brief at 33, Harris v. Forklift Sys., Inc., 510 U.S. 17 (1993) (No. 92-1168). This strategy, of course, invited counsel for Forklift Systems to stress that much of the conduct was not sexual in nature and that such nonsexual conduct rarely rises to the level of affecting the terms and conditions of employment. See Respondent's Brief at 28. Only in the reply brief, presumably after seeing the point raised by a couple of amici, see infra note 140, did Harris's counsel argue that Hardy's denigration of Harris's competence was "especially demeaning to a person in a managerial position," Petitioner's Reply Brief at 9.

140. See, e.g., Brief Amici Curiae of the Employment Law Center et al. in Support of Petitioner; Bricf Amici Curiae in Support of Petitioner on Behalf of National Conference of Women's Bar Associations and 
narrow obsession with the lack of direct sexual advances on Harris as problematic.

\section{B. Disaggregation in the Lower Courts}

The lower court's decision in Harris and the Seventh Circuit's decision in King v. Board of Regents of the University of Wisconsin System exemplify the most prominent feature of hostile work environment jurisprudence: the disaggregation of sexual advances and other conduct that courts consider "sexual" in nature from other gender-based mistreatment that judges consider nonsexual. Although disaggregation of the sexual from the nonsexual occurs in different doctrinal contexts, ${ }^{141}$ typically it arises in connection with allocating the challenged conduct to different claims for purposes of deciding

Women's Bar Association of the District of Columbia: Brief Amici Curiae of the NAACP Legal Defense and Educational Fund, Inc. and the National Council of Jewish Women in Support of Petitioner, Brief Amicus Curiae of the National Employment Lawyers Association in Support of Petitioner. Brief of Amici Curiae NOW Legal Defense and Education Fund et al.: Brief of the Southem States Police Benevolent Association and the North Carolina Police Benevolent Association, as Amici Curize; Brief of the Women's Legal Defense Fund et al.

Two exceptions stand out. The brief filed by Feminists for Free Expression urged the Court to clarify that the definition of hostile work environment harassment includes all gender-based conduct, not only conduct of a "sexual" nature as suggested in the EEOC guidelines. See Brief of Amicus Curize Feminists for Free Expression in Support of Petitioner at *7, available in LEXIS. Genfed Library. Briefs File. The group argued that the courts' current focus on sexuality perpetuates a harmful stereotype that women need to be protected from sexual speech and risks prohibiting specch that is protected by the First Amendment. See id. The brief filed by the United States and the EEOC urged the Count to reject a psychological injury requirement in favor of a requirement of proof that the harassment was sufficiently severe or pervasive to interfere with a reasonable person's job performance. See Brief for the United Stules and the Equal Employment Opportunity Commission as Amici Curiae at *8, available in LEXIS. Genfed Library. Briefs File. The brief pointed out that harassment could include nonsexual conduct and that even explicitly sexual conduct can be understood to inhibit job performance by "hamper[ing] [a woman's] opponunity to succeed vis-à-vis her male peers or den[ying] her credit for her achievernents." Id. at $\bullet 12$.

141. Sometimes the disaggregation of sexual and nonsexual conduct occurs in the context of a court's ruling on whether the two types of conduct constitute a continuing violation that operates to toll the stalute of limitations. Courts often conclude that the sexual conduct considered in connection with the hostile work environment claim is not part of a larger pattern of discriminatory practices, including the nonsexual conduct, which is analyzed as disparate treatment; accordingly. they dismiss one set of claims or the other. See, e.g., Hunt-Golliday v. Metropolitan Water Reclamation Dist., No. 94-C-3559. 1994 U.S. Dist. LEXIS 17318 , at $* 12-15$ (N.D. Ill. Dec. 6, 1994) (holding that, even though the plaintiff's harassment was precipitated by her having the temerity to challenge her supervisor's failure to assist her in obtaining a promotion, her promotion denial was not part of a continuing violation with the harassment it triggered and thus was time-barred); Jensvold v. Shalala, 829 F. Supp. 131, 138 (D. Md. 1993) (holding that, although the plaintiff's being told that her research was not valued and did not justify her continued presence on the job constituted an act of disparate treatment that occurred during the relevant time period. the plaintiff's hostile work environment claim was nonetheless time-barred because the two claims were "factually and legally distinct"); Sandom v. Travelers Mortgage Servs., Inc., 752 F. Supp. 1240, 1247-48 (D.NJ. 1990) (holding similarly); see also Boarman v. Sullivan, 769 F. Supp. 904, 907-08 (D. Md. 1991) (concluding that the plaintiff's allegation of a pattern or practice of discrimination in promotions was not reasonably related to her hostile work environment harassment claim, and thus could not survive plaintiff's failure to allege her promotion claim specifically in her EEOC charge): Bennelt v. New York City Dep't of Corrections, 705 F. Supp. 979, 982 (S.D.N.Y. 1989) (holding that the plaintifr's allegation that the department discriminatorily refused to provide her with the training she needed to advance was not reasonably related to the sexual advances and touchings underlying her hostile work environment claim. and thus could not survive her failure to allege specifically the denial of training in her EEOC charge). 
whether the conduct violates Title VII. Courts decide, explicitly or implicitly, that only overtly sexual conduct counts toward establishing hostile work environment harassment and that nonsexual conduct must be considered-if at all-as a separate form of disparate treatment.

\section{Hostile Work Environment Versus Disparate Treatment}

The disaggregation of sexual and nonsexual conduct was not inevitable, for hostile work environment harassment emerged as a variant of disparate treatment. ${ }^{142}$ The essence of a hostile work environment claim is that actions for which the defendant is responsible have made the work environment more difficult for women (or men) because of their sex. Indeed, the original impetus behind creating the cause of action was to ensure that the prohibition against discrimination extended to actions that did not in and of themselves effect a tangible job detriment. The first decision that articulated the concept of hostile work environment harassment, Rogers v. EEOC, ${ }^{143}$ demonstrates this point. In Rogers, the Fifth Circuit held that a Hispanic worker's allegation that her optometrist employers had discriminated against her on the basis of national origin by segregating patients along ethnic lines stated a Title VII violation sufficient to support an EEOC investigation. Although the optometrists' actions toward their patients did not affect the complainant's or any other employee's job in any tangible economic sense, the court recognized that working in a place where members of one's group are subjected to discriminatory service may create an atmosphere of inferiority and discrimination for minority workers. In a passage that laid the conceptual foundation for the hostile work environment harassment claim, the court concluded that

employees' psychological as well as economic fringes are statutorily entitled to protection from employer abuse, and that the phrase "terms, conditions, or privileges of employment" [in Title VII] is an expansive concept which sweeps within its protective ambit the practice of creating a working environment heavily charged with ethnic or racial discrimination. ${ }^{14}$

The Supreme Court extended this reasoning to cover sex-based hostile work environments in Meritor Savings Bank v. Vinson. ${ }^{145}$

Despite the origin of hostile work environment harassment in the law of disparate treatment, courts have developed analyses that distinguish the two causes of action and endow each with a life of its own; to many courts, the

142. I am grateful to my former boss and mentor, David L. Rose, the former chicf of the Employment Litigation Section of the U.S. Department of Justice, Civil Rights Division, for helping me see this point. 143. 454 F.2d 234 (5th Cir. 1971).

144. Id. at 238 (quoting 42 U.S.C. $\$ 2000 \mathrm{e}-2(\mathrm{a})(1)$ ).

145. 477 U.S. $57,65-66$ (1986). 
two claims have become "factually and legally distinct." $1+6$ Although Rogers was meant to clarify that Title VII's prohibition against discrimination in "terms, conditions, or privileges of employment" covers any type of employment-related action, regardless of whether the accompanying harm is psychological, economic, or otherwise, some courts have held that disparate treatment claims are confined to supervisor actions that effect a tangible job detriment. ${ }^{147}$ Other courts have gone even further to demand proof that the alleged misconduct constituted an "ultimate employment decision," $\$ 8$ such as hiring, firing, pay, or promotion denial. The cause of action for hostile work environment harassment, however, was devised precisely to cover situations that do not affect the plaintiffs' jobs in any tangible or ultimate sense. As a result, there is no requirement that alleged hostile work environment

146. Jensvold, 829 F. Supp. at 138.

147. See, e.g., King v. Board of Regents of the Univ. of Wis. Sys., 898 F.2d 533. 541 (7th Cir. 1990) (concluding that an assistant professor could challenge the ultimate decision to deny her tenure as a form of disparate treatment, but could not challenge allegedly discriminatory mistreatment by the director of her program because "no term, condition or privilege of employment was affected as a result of these actions"). discussed supra Section I.C; Page v. Bolger, 645 F.2d 227, 233 (4th Cir. 1981) (en banc) (concluding that a black postal service employee could challenge the ultimate decision to deny him a promotion as a form of disparate treatment, but could not challenge the all-white composition of the review board as an independent form of disparate treatment because the latter, as an "interiocutory or mediate decision[] having no immediate effect upon employment conditions," was not an "'ultimate employment decision" (quoung 42 U.S.C. \& 2000e-17)). But see Rimedio v. Revlon. Inc.. S28 F. Supp. 1380. 1389 (S.D. Ohı 1982) (concluding that the plaintiffs were subjected to disparate treatment in terms and conditions of employment where the defendant "did not give the women as much authority as the men or treat the women with as much professional respect as their male counterparts... [and] did [not] treat them as farly as he treated the men with regard to setting goals or in the evaluation of their job performance"): EEOC v. Judson Steel Co., 33 Fair Empl. Prac. Cas. (BNA) 1286, 1295 (N.D. Cal. 1982) (concluding that the plaintuffs were subjected to disparate treatment where they were "treated differently in the assignment of work. overume. breaks, and other day-to-day conditions of employment ... [and where] they were harassed by their supervisor, and [one] was subjected to sexual advances").

148. Mattem v. Eastman Kodak Co., 104 F.3d 702, $707-08$ (5th Cir. 1997) (construing Page to bar a retaliation claim on the ground that no ultimate employment decision was involved where the alleged retaliation consisted of an investigatory visit to the plaintiff's home by her supervisor, a reprimand for being away from her desk, negative performance reviews that resulted in a missed pay increase, an intensification of her work by her supervisors, and hostility and false reports of problems with her work from her coworkers); accord Dollis v. Rubin, 77 F.3d 777. $781-82$ (5th Cir. 1995) (barring a retaliation clam on the ground that no ultimate employment decision was involved where the plaintiff alleged that she was denied a desk audit to determine her eligibility for a promotion, denied the oppontunity to attend a trainıng conference, subjected to unusual scrutiny by her supervisor. and humilialed by her supervisor's aet of informing her client that she made an error); Raley v. Board of St. Mary's County Comm'rs, 752 F. Supp. 1272,1278 (D. Md. 1990) (barring a disparate treatment claim on the ground that no ultumate employment decision was involved where the plaintiff alleged that her supervisor subjected her to sexual touchings and propositions, gave her an unsatisfactory performance evaluation that he later changed to satusfactory, and gave her a reprimand that he later rescinded when she filed a gnevance aganst hum): id. al 1280-81 (barring the plaintiff's retaliation claim on the ground that no ultimate employment decision was involved); Lewis v. Glickman, No. 96-0358, 1997 U.S. Dist. LEXIS 7382, al *13-17 (E.D. Lo. May 14, 1987) (barring a disparate treatment claim on the ground that no ultimate employment decision was involved where the plaintiff alleged that he was discriminatorily denied training on the basis of race). But see Negussey $v$. Syracuse Univ., No. 95-CV-1827, 1997 U.S. Dist. LEXIS 3853. at •18-37 (N.D.N.Y. Mar. 24. 1997) (construing Page more narrowly to bar disparate treatment elaims only where the plainuff has sought to challenge "merely the first or second step in the decisionmaking process." and hence the case was nol yet ripe for resolution because a final employment decision had not been made): Howze v. Virginia Polytechnic, 901 F. Supp. 1091, 1097 (W.D. Va. 1995) (same). 
harassment affect an ultimate employment decision. Instead, plaintiffs are required to prove two alternative elements: First, they must show that the harassment is "sufficiently severe or pervasive to alter the conditions of the victim's employment and create an abusive working environment"; ${ }^{49}$ and second, they must also prove that the employer is responsible legally for the challenged misconduct. ${ }^{150}$

Judges have also created another distinction between hostile work environment harassment and disparate treatment: They have sexualized the hostile work environment claim by singling out sexual advances and other sexually oriented conduct as the essence of harassment. To establish a hostile work environment, most courts have required proof not only that the harassing conduct occurred "because of sex"-the standard causation inquiry that is essential to any Title VII discrimination claim including disparate treatment ${ }^{151}$ - but also that the conduct is sexual in nature.

\section{2. "Sexual" Versus "Nonsexual" Conduct}

Many courts have relied explicitly on the nonsexual character of the alleged misconduct to dismiss altogether plaintiffs' hostile work environment claims. In Turley v. Union Carbide Corp. ${ }^{152}$ for example, a court granted summary judgment against the hostile work environment claim of a woman who complained that her foreman harassed her by "picking on [her] all the time" and treating her differently from the male employees. ${ }^{153}$ According to the judge, "[T] here [were] no facts which would support a finding of sexual harassment as that term has come to be used in employment discrimination

149. Vinson, 477 U.S. at 67, quoted in Harris v. Forkift Sys., Inc., 510 U.S. 17, 21 (1993). The severity and pervasiveness element is a judge-made requirement for satisfying the "terms, conditions, or privileges of employment" language of Title VII; there is nothing in the statutory language itself that demands such proof. The courts might have construed the "terms, conditions, or privileges of cmployment" phrase to cover any conduct that makes it more difficult for a worker or group of workers to do their jobs because of their sex, so long as it is conduct for which the company is legally responsible.

150. In some circuits, plaintiffs must prove that the employer knew or should have known of the alleged misconduct and failed to take prompt remedial action, regardless of whether that conduct occurred at the hands of supervisors or it occurred at the hands of coworkers. See id. at 69-72; Henson v. City of Dundee, 682 F.2d 897, 905 (11th Cir. 1982). In some circuits, a plaintiff may also hold an employer vicariously responsible for a supervisor's hostile work environment harassment by showing that the supervisor acted within the scope of his employment, or was aided by the existence of an agency relationship, or satisfied other agency principles. See, e.g., Faragher v. City of Boca Raton, 111 F.3d 1530, 1534 (11th $\mathrm{Cir}$ ) (discussing standards adopted by courts of appeals in the wake of Vinson), cert. granted, 118 S. Ct. 438 (1997).

151. In United States Postal Service v. Aikens, 460 U.S. 711, 715 (1983) (citations omitted), the Court wrote that "[t]he 'factual inquiry' in a Title VII case is '[whether] the defendant intentionally discriminated against the plaintiff.' In other words, is 'the employer . . . treating "some people less favorably than others because of their race, color, religion, sex, or national origin."' As this quotation suggests, in most disparate treatment cases, the questions of intent and causation merge: The law presumes that an employer acted with discriminatory intent when it or its agents treated an employee or group of employees differently on the basis of a prohibited classification.

152. 618 F. Supp. 1438 (S.D. W. Va. 1985).

153. Id. at 1442 . 
law." 154 The court rested this conclusion on the fact that the "[p]laintiff was not subjected to harassment of a sexual natur. The foreman did not demand sexual relations, he did not touch her or make sexual jokes." 155 Although not bound by them, the court cited the EEOC guidelines, which define harassment as "[u]nwelcome sexual advances, requests for sexual favors and other verbal or physical conduct of a sexual nature." ${ }^{156}$ According to the court:

[T] he guidelines provide insight into the nature of a sexual harassment theory. The theory rests upon conduct which can be characterized as sexual. "Sex" in this instance does not mean gender. Rather, it is used pursuant to its more popular meaning. Thus, while the harassment may be directed at a member of the female sex, it is a harassment which plays upon the stereotypical role of the female as a sexual object. $^{157}$

To buttress its conclusion, the court appealed to the authority of Professor MacKinnon: "Sexual harassment has been defined as 'the unwanted imposition of sexual requirements in the context of a relationship of unequal power."'158

Turley exemplifies the sexual desire-dominance paradigm with exceptional clarity. Other cases, however, have adopted similar reasoning. In Walker $v$. Sullair Corp. ${ }^{159}$ for example, the court dismissed a hostile work environment claim with this explanation:

Sexual harassment based on a hostile work environment exists where there are sexual advances, fondling or a sexually suggestive workplace atmosphere that the claimant finds unwelcome... Walker has offered no proof of an unwelcome touching or fondling. . . Rather, the conduct alleged included close monitoring of the attendance of the plaintiff, monitoring of personal phone calls, public reprimands for poor job performance and various other nonsexual harassment. ${ }^{160}$

Likewise, in Hosemann v. Technical Materials, Inc., ${ }^{161}$ the cour dismissed the plaintiff's allegations that one of her coworkers had sabotaged her work and "always ... tried to make her do her work poorly," 162 that another had “"embarrassed [her] every work day ... by not talking very good about

154. Id.

155. Id.

156. EEOC Guidelines on Discrimination Because of Sex, 29 C.F.R. $\$ 1604.11$ (a) (1983), quoted in Turley, 618 F. Supp. at 1441 . The plaintiff's claim was brought under the state employment discrimination statute, rather than under Title VII; "therefore, the Guidelines [were] not expressly applicable." Turley, 618 F. Supp. at 1441 .

157. Turley, $618 \mathrm{~F}$. Supp. at $1441-42$ (citations omitted).

158. Id. at 1441 (quoting MACKINNON, supra note 83, at 1).

159. 736 F. Supp. 94 (W.D.N.C. 1990), rev'd in part and aff'd in part. 946 F.2d 888 (4th Cir. 1991 ).

160. Id. at 100 .

161. 554 F. Supp. 659 (D.R.I. 1982).

162. Id. at 663 . 
females," ${ }^{163}$ and that her supervisors had badgered her with daily phone calls about when she would return to work while she was recovering from an injury, even though her male coworkers had been permitted reasonable disability leaves. ${ }^{164}$ The court concluded that the plaintiff had not alleged "sexual harassment as that term has come to be defined."165

Many other cases have held expressly that conduct that is not sexual in nature does not-and cannot-constitute hostile work environment harassment. ${ }^{166}$ Indeed, in a number of circuits, an element of the cause of action for hostile work environment harassment is proof of unwelcome sexual advances or other verbal or physical conduct of a sexual nature. ${ }^{167}$ In other cases, the emphasis on sexual conduct is less explicit. Instead of dismissing plaintiffs' claims before trial, some courts have ruled against plaintiffs after trial on the ground that the challenged conduct is not sufficiently sexual to comprise a hostile work environment. ${ }^{168}$ In these cases, plaintiffs lose on the

163. Id. at $663 \mathrm{n} .11$ (quoting the plaintiff's answers to the defendant's interrogatories).

164. See id. at 661-62.

165. Id. at 666 .

166. See, e.g., Downes v. FAA, 775 F.2d 288, 290 (Fed. Cir. 1985) ("Sexual harassment is used herein in the sense of offensive behavior of a sexual nature which is prohibited by Title VII."); Holmes v. Razo, No. 94 C 50405, 1995 U.S. Dist. LEXIS 10599, at *18 (N.D. Ill. July 18, 1995) (concluding that the plaintiff's complaint does allege behavior of a "sexual nature" on the part of the defendant and thus "there is no deficiency in the sexual content of the discriminatory actions" for purposes of a hostile work environment claim); Sassaman v. Heart City Toyota, 879 F. Supp. 901,908 (N.D. Ind. 1994) (stating that the plaintiff must prove that she "suffered sexual misconduct having the purpose or effect of unreasonably interfering with her work performance or creating an intimidating, hostile or offensive environment"); Reynolds v. Atlantic City Convention Ctr., 53 Fair Empl. Prac. Cas. (BNA) 1852, 1856 (D.N.J. 1990) (considering only sexually obscene gestures and words as "sexual harassment"), aff'd, 925 F.2d 419 (3d Cir. 1991), discussed infra text accompanying notes 183-196.

167. See, e.g., Yeary v. Goodwill Indus.-Knoxville, Inc., 107 F.3d 443, 445 (6th Cir. 1997) (requiring the plaintiff to show that he was "subjected to unwelcome... sexual harassment in the form of sexual advances, requests for sexual favors, or other verbal or physical conduct of a sexual nature"' (quoting Rabidue v. Osceola Ref. Co., 805 F.2d 611, 619-20 (6th Cir. 1986))); Mattem v. Eastman Kodak Co., 104 F.3d 702, 706 (5th Cir. 1997) (imposing a similar requirement); Fuller v. City of Oakland, 47 F.3d 1522, 1527 (9th Cir. 1995) (requiring the plaintiff to show that "she was subjected to verbal or physical conduct of a sexual nature"); see also Cosgrove v. Sears, Roebuck \& Co., 9 F.3d 1033, 1042 (2d Cir. 1993) (requiring the plaintiff to show she was the subject of "unwelcome advances," though not explicitly stating that such advances must be sexual).

168. See, e.g., Morrison v. Carleton Woolen Mills, Inc. 108 F.3d 429, 438, 440 (1st Cir. 1997) (upholding a jury's verdict of hostile work environment harassment of a mill floor person based on sexual misconduct that occurred prior to November 21, 1991 on the ground that "there was ample evidence of crude, demeaning, and sexually-oriented behavior by [the plaintiff's supervisor] and others directed at Morrison," but affirming a grant of judgment notwithstanding the verdict for the period thereafter, on the ground that the nonsexual harassment of which the plaintiff complained did not subject her to "sexually offensive, embarrassing or vulgar conduct or remarks, or other sex-based conduct or remarks, such as had occurred prior to November 21, 1991"); Downes, 775 F.2d at 294 n.5 \& 295 (reversing an agency finding that a safety inspection supervisor had created a hostile work environment by referring to a female employee as the "Dolly Parton" of the office, speculating about her sex life, and touching her hair, while noting that hair touching "may or may not be a sexual gesture" and dismissing as irrelevant and "rambling" the employee's allegations of nonsexual harassment); Quick v. Donaldson Co. Inc., 895 F. Supp. 1288, 1296 (S.D. Iowa 1995) (concluding that a heterosexual male press operator's treatment by male coworkers who "bagged" his testicles by intentionally grabbing and squeezing them did not constitute actionable harassment, because bagging "did not involve any sexual suggestions or interests" by the plaintiff's coworkers); Galloway v. General Motors Serv. Parts Operations, No. 92 C 5987, 1994 U.S. Dist. LEXIS 16902 , at $* 7$ (N.D. Ill. Nov. 23, 1994) (concluding that a female auto worker's harassment by a male 
severity or pervasiveness element rather than on the sexual conduct element.

The underlying reasoning of these cases is that the conduct does not sufficiently resemble sexual advances-or does not seem sufficiently motivated by sexual interest-to be actionable. In Wimberly $v$. Shoney's, Inc., ${ }^{169}$ for example, five former waitresses alleged that their manager, Zavonar, and some of their male coworkers had subjected them to grossly abusive conduct because of their sex. Concluding that "only shocking and pervasive sexually oriented misconduct amount[s] to a Title VII violation," whether all the alleged misconduct together had created a hostile work environment. Instead, the court analyzed each incident separately and ruled against the plaintiffs on all but one of their claims. The plaintiffs claimed, for example, that Zavonar had a habit of putting his arm around them and letting his arm and hands fall close to their chests. The court dismissed such conduct based on Zavonar's statement that "[i]f he did it, . . it was done without sexual designs." ${ }^{\text {"171 }}$ One woman complained that she had been inadequately trained and had therefore received a poor performance report. When she cried about this in Zavonar's office, he allegedly pulled her close and said he "would train her his way"172 in a "tone of voice [that] was anything but comforting." 173 Although Zavonar conceded that he did "grasp [this plaintiff] by the shoulders in an attempt to calm her down and stop her crying," the court dismissed Zavonar's assault, ratifying his claim that "he never intended it to be a sexual proposition." 174 The plaintiffs also claimed that Zavonar "had a 'filthy' mouth, . . . often calling waitresses 'bitches,' [and] telling them to 'get off their lazy damn asses."'175 Although the plaintiffs clearly objected to this conduct, the court dismissed their objections with the observation that "none of the plaintiffs testified that Zavonar's profanity was sexually abusive." 176 Finally, with respect to three of the plaintiffs, the court emphasized that Zavonar had not committed quid pro quo harassment. As the court explained in reference to one of these women, "Plaintiff admitted that

coworker with whom she had broken off a relationship was nol sufficiently severe or pervasive to creale a hostile work environment where the harasser's continually "calling plaintiff a 'sick bitch' was not overtly sexual in nature"); see also Young v. Mariner Corp., 56 Empl. Prac. Dec. (BNA) q 40.814, at 40.867 (N.D. Ala. 1991) (refusing to credit a female hotel caterer's allegation that her general manager made sexual advances toward her by noting that, "at the time of the alleged sexual advance. [the plaintiff] wore litte or no make-up and her hair was not colored in any way." and concluding that. "considenng the appearance of [the general manager's] wife, it is obvious that [the plaintiff's] appearance at the tume was not attractuve to [the general manager]").

169. 39 Fair Empl. Prac. Cas. (BNA) 444 (S.D. Ga. 1985).

170. Id. at 453 (citing Katz v. Dole, 709 F.2d 251 (4th Cir. 1983); Henson v. City of Dundec, 682

F.2d 897 (11th Cir. 1982); Bundy v. Jackson, 641 F.2d 934 (D.C. Cir. 1981)).

171. Id. at 448 .

172. Id. at 447.

173. Id.

174. Id.

175. Id. at 448 .

176. Id. 
Zavonar never demanded sex from her as a condition for keeping her job. . . . [He] neither propositioned her nor talked explicitly about sex to her."177

Other courts have been even more subtle. In perhaps the largest group of cases, courts have simply taken for granted that nonsexual conduct cannot contribute toward establishing a hostile work environment. These courts have merely proceeded, without analysis, to examine only the sexually explicit conduct for the hostile work environment claim and to consider the nonsexual conduct, if at all, under a separate disparate treatment analysis-each in isolation from the other. ${ }^{178}$ As I discuss more fully below, such approaches drain harassment law of its ability to address the full range of gender-based hostility at work.

\section{The Harms of Disaggregation}

The problem with disaggregation should be obvious by now. It weakens the plaintiff's case and distorts the law's understanding of the hostile work environment by obscuring a full view of the culture and conditions of the workplace. Both the hostile work environment and the disparate treatment

177. Id. Consider also the court's similar statements about two of the other plaintiffs: "Plaintiff [Lec] testified that Zavonar neither propositioned her nor demanded, either explicitly or implicitly, that she submil to sexual advances in order to keep her job." Id. at 449. "Plaintiff [Boring] admitted on cross-examination that Zavonar neither tried to fondle, pinch or proposition her, nor required sex in exchange for job benefits." Id. at 450 .

178. See, e.g., King v. Board of Regents of the Univ. of Wis. Sys., 898 F.2d 533 (7th Cir. 1990), discussed supra Section I.C; Rabidue v. Osceola Ref. Co., 805 F.2d 611, 624 (6th Cir. 1986) (Keith, J., concurring in part and dissenting in part) (considering in connection with a discriminatory discharge claim, but not a hostile work environment claim, allegations that the sole female manager in an oil refinery was denied perks and prerequisites needed to perform the job, was preciuded from taking customers to lunch, and was seated with female clerical employees at a company meeting), discussed infra text accompanying notes 380-384; Davis v. Boeing Helicopter Co., No. 88-0281, 1990 U.S. Dist. LEXIS 11990, at *13-18 (E.D. Pa. Sept. 12, 1990) (considering in connection with a discriminatory demotion claim, but not a hostile work environment claim, an aircraft electrician's allegations that she was told that women do not belong in the job, her coworkers were told not to help her because of her sex, and her work progress was checked every few minutes); Graham v. American Airlines, Inc., 731 F. Supp. 1494, 1499 (N.D. Okla. 1989) (considering in connection with a disparate treatment claim, but not a hostile work environment claim, an aircraft mechanic's allegations that she was disciplined for failure to tighten a bolt and was demoted unless and until she passed a qualifying exam, and disregarding altogether plaintiff's allegation that her coworkers altered a newspaper article to suggest that she had received notoriety for poor job performance); Anderson v. Chicago Hous. Auth., No. 86-C-0449, 1988 U.S. Dist. LEXIS 14454, at *18-25 (N.D. Ill. Dec. 20, 1988) (considering in connection with a disparate treatment claim, but not a hostile work environmental claim, an assistant maintenance superintendent's allegation that her supervisor refused to assign her any supervisory duties and instructed her subordinates to give her orders, and considering for the hostile work environment claim only her supervisor's sexual proposition and comment about the plaintiff's breasts); Loftin-Boggs v. City of Meridian, 633 F. Supp. 1323, 1325 (S.D. Miss. 1986) (excluding from consideration under a hostile work environment claim a chemist's allegation that she was excluded from staff meetings, publicly reprimanded and wrongfully accused of misusing purchase orders, and considering only her supervisor's cursing and sexual banter), aff'd, 824 F.2d 971 (5th Cir. 1987); Altschuler v. Walters, 34 Fair Empl. Prac. Cas. (BNA) 522, 531 (E.D. Pa. 1983) (considering in connection with a discriminatory denial of promotion claim, but not a hostile work environment claim, a speech pathologist's allegation that her supervisor suggested that she should be home with her children and restricted her supervisory and other duties). 
claims are trivialized. When removed from the Iarger discriminatory context, the sexual conduct can appear insignificant. For this reason, courts often conclude that the harassment was not sufficiently severe or pervasive to alter the conditions of employment and create a hostile or abusive work environment. ${ }^{179}$

By the same token, when women are denied the training, information, and support they need to succeed on the job, or when they are subjected to threatening or alienating acts that undermine their confidence and sense of belonging, they can easily be made to appear (or even become) less than fully proficient at their jobs. This lack of proficiency then becomes the nondiscriminatory reason that justifies the hostile treatment that has undermined their competence. Furthermore, when separated from sexual advances and other sexual conduct, the nonsexual actions may appear to be gender-neutral forms of hazing with which the law should not interfere. For these reasons, courts frequently rule against plaintiffs on the ground that acts were not directed at them because of their sex. ${ }^{180}$

What is more, some nonsexual forms of hostility escape judicial scrutiny altogether. They appear as insufficiently sexual to be analyzed as hostile work environment harassment, and too remotely related to a tangible job benefit to constitute disparate treatment. ${ }^{181}$ Harmful acts of hazing and harassment frequently fall between the cracks of legal analysis altogether. ${ }^{182}$

179. For recent examples, see Ramsey v. Cin' of Denver, 907 F.2d 1004 (10th Cir. 1990), diseussed infra text accompanying notes 259-268; Scont v. Sears, Roebuck \& Co., 798 F.2d 210 (7th Cir. 1986). discussed infra notes 197-209 and accompanying text; the lower court's decision in Harris v. Forklift Systems, Inc., 60 Empl. Prac. Dec. (CCH) 9 42,070, at 74,247 (M.D. Tenn. 1991), aff ${ }^{\circ}$. 976 F.2d 733 (6th Cir. 1992) (per curiam), rev'd, 510 U.S. 17 (1993), discussed supra Soction Il.A; Reynolds v. Atlantic Ciry Convention Center, 53 Fair Empl. Prac. Cas. (BNA) 1852 (D.N.J. 1990), aff'd. 925 F.2d 419 (3d Cir. 1991), discussed infra text accompanying notes 183-196; and Ross $v$. Double Diamond Inc., 672 F. Supp. 261 (N.D. Tex. 1987), discussed infra text accompanying notes 212-225.

180. For recent examples, see Gross v. Burggraf Construcrion Co., 53 F.3d 1531 (10th Cir. 1995), discussed infra notes 271-285 and accompanying text; Ramsey, 907 F.2d 1004 (10th Cir. 1990), discussed infra text accompanying notes 259-268; Scont. 798 F.2d 210 (7th Cir. 1990), discussed infra notes 197-209 and accompanying text; Reynolds, 53 Fair Empl. Prac. Cas. (BNA) 1852 (D.N.J. 1990), discussed infra text accompanying notes 183-196; and additional sources discussed infra Par III.C.

181. See supra text accompanying notes 115-126.

182. See Scott, 798 F.2d 210 (7th Cir. 1990), discussed infro notes $197-209$ and accompanying text: Reynolds, 53 Fair Empl. Prac. Cas. (BNA) 1852 (D.NJ. 1990), discussed infra text accompanying notes 183-196; see also Raley v. Board of St. Mary's Comm'rs, 752 F. Supp. 1272. 1280-81 (D. Md. 1990) (refusing to consider under a hostile work environment elaim the plaintiff's allegations thal she was assigned clerical work outside of her job description, given an unsatisfactory performance evaluation, and had a letter of reprimand placed in her file, and concluding that such allegations were not adverse employment actions sufficient to ground a disparate treatment of retaliation claim): Graham. 731 F. Supp. at 1500-01 (declining to consider under a hostile work environment claim or discriminatory firing claum plaintiff's allegations that she was subjected to discriminatory assignments and discipline, forced to take a qualifying test to keep her job, and humiliated by a newspaper article that had boen altered to suggest that she had achieved notoriety for poor job performance); Sapp v. City of Wamer Robins, 65S F. Supp. 1043, $1049-50$ (M.D. Ga. 1987) (declining to consider under a hostile work environment or promotion discrimination claim the plaintiff's allegations that she was denied the opportunity to go home for lunch. refused her request to post notice for a substitute when she was sick. and reprimanded for her atrire); Loftin-Boggs, 633 F. Supp. at 1326-27 (declining to consider under a hosule work environment or constructive discharge claim the plaintiff's exclusion from staff moetings, public reprimands, and wrongful 
Reynolds v. Atlantic City Convention Center ${ }^{183}$ provides an illustration. Margaret Reynolds, a female journeyman electrician, claimed that she had been subjected to a campaign of constant harassment after she was named subforeman for a construction job at Atlantic City's convention center. The harassment did not take the form of sexual advances or other sexually oriented conduct. Instead, it consisted of conduct that challenged Reynolds's authority and right to be subforeman. The men refused to work for her and stood around laughing while she unloaded heavy boxes. They engaged in a work stoppage-some even quit their jobs-so as not to submit to the authority of a woman. She not only was "harassed constantly with verbal abuse and obscene gestures,"184 but also complained of "the tenseness of the job, looks we were getting, people not talking to us, leaving the room, things of that effect." 185 Reynolds's shop steward was also part of the problem. He refused to obtain locks for the shower she and her lone female coworker shared; and when Reynolds and the other woman complained to the shop steward about the lack of disability benefits, he "told them the men had not complained to him about benefits, and the women should quit if they did not like the lack of benefits." 186 Finally, when a client exhibitor demanded that Reynolds and the other female electrician be removed from the floor during the Miss America Pageant-apparently the incongruity between the images of the pageant contestants and the tradeswomen was too much for the exhibitor-Reynolds and her colleague were replaced by a male coworker. At the end of the pageant, the convention center's director fired the whole crew and hired all but the plaintiff and a few others back the next day, with a man as the new subforeman. Reynolds alleged "that the entire crew was fired to enable the Center to ... fire her because she was a woman and the Center wanted a male subforeman.,"187

Although Reynolds herself considered all these actions to be forms of harassment that established a hostile work environment, ${ }^{188}$ the court relied on the EEOC guidelines to conclude that only conduct of a "sexual nature" could count. The court first bifurcated the "obscene gestures and words" it considered "sexual harassment" from the incidents it characterized as "other

accusations of misuse of purchase orders).

183. 53 Fair Empl. Prac. Cas. (BNA) 1852 (D.N.J. 1990), aff'd, 925 F.2d 419 (3d Cir. 1991).

184. Id. at 1855 .

185. Id. at 1856 .

186. Id. at 1857.

187. Id.

188. See id. at 1856 (reporting the plaintiff's complaint that, in addition to conduct the court characterized as sexual harassment, "a variety of other [nonsexual] events occurred which she alleges amount to sexual harassment," events which the court described under the heading "other harassment"); id. at 1867 (reporting the plaintiff's allegation that, in addition to conduct which the court referred to as "Obscene Gestures and Words," other nonsexual incidents of harassment provided grounds for her hostile work environment claim). 
harassment."189 Because the "sexual harassment" included only one coworker giving the plaintiff the finger, another shaking his crotch at her, and two others calling her offensive names, the court concluded that it was not sufficiently severe or pervasive to be actionable. ${ }^{190}$ The court next examined the "other harassment," analyzing "each incident individually to determine first whether it was sexual in nature."191 According to the court, none of the challenged incidents provided evidence of a hostile work environment: ${ }^{192}$ "While her male co-workers may have refused to work for her because she was a woman, such refusal is not 'verbal or physical conduct of a sexual nature' and so does not figure into the calculus of a sexually offensive working environment."193 The court examined each of Reynolds' allegations one by one and rejected them all based on this line of reasoning.

Given the court's approach, it was a foregone conclusion that the court would grant summary judgment against Reynolds on her hostile work environment claim. Further, even though the court held that the nonsexual incidents were not part of a hostile work environment claim, it did not address any of these incidents, other than the plaintiff's firing, under a separate disparate treatment analysis. The nonsexual mistreatment evaded legal analysis and liability-despite a concession by the court that some of this conduct may have been directed at Reynolds because of her sex. ${ }^{194}$

The court also granted summary judgment against Reynolds on her discriminatory discharge claim, holding that no reasonable jury could conclude that the crew had been let go out of a desire to get rid of the plaintiff as subforeman because of her sex. ${ }^{195}$ In light of the court's approach, this result is not surprising: Only by considering the decision to fire Reynolds in the context of the earlier actions to undermine her position as subforeman could the firing have emerged as part of a gender-based pattern to drive her away from the job. Yet, the court not only failed to link her discharge claim with these earlier incidents of harassment, but it also deemed a previous statement by the union business manager too remote to count as direct evidence of discriminatory intent. Only a year earlier, when the foreman who eventually named Reynolds as subforeman had proposed naming her to that position, the business manager proclaimed: " $[N]$ ow is not the time, the place or the year or will it ever be the year for a woman foreman." 196

189. Id. at 1856-57 (distinguishing "sexual harassment" from "other harassment"): td. at 1866-67 (distinguishing "obscene gestures and words" from "other harassment").

190. See id. at $1866-67$.

191. Id. at 1867.

192. See id.

193. Id. (quoting EEOC Guidelines on Discrimination Because of Sex. 29 C.F.R. $\$ 1604.11$ (a) (1981)).

194. See id. (acknowledging that male coworkers may have refused to work for Reynolds because she was a woman).

195. See id. at 1867 .

196. Id. at 1863. 
Scott v. Sears, Roebuck \& Co. ${ }^{197}$ provides another example of this disaggregation. Maxine Scott was hired as an auto mechanic trainee by Sears as part of a program initiated by the Chicago Alliance of Business and Employment Training to train women in nontraditional fields; her position was subsidized by federal Comprehensive Employment and Training Act (CETA) funds. After a brief twelve-week training course, she was placed under the supervision of a senior mechanic, Eddie Gadberry, who was to give her on-the-job training in repairing brakes. Gadberry treated her as his plaything and did not train her: $\mathrm{He}$ "repeatedly propositioned her, would wink at her and also suggested he give her a rub-down."198 Moreover, "when she asked for advice or assistance, Gadberry would often reply, 'what will I get for it?"'199 Other mechanics followed Gadberry's lead: One slapped her on the rear end, and another speculated about her demeanor while having sex. When Scott's CETA subsidy ended, she was dismissed (along with the only other female mechanic). Sears argued that Scott was dismissed because she was less productive than the men. Scott argued that, if so, her lower productivity stemmed from her inadequate training for brake jobs (she had often been assigned to do more menial tire and battery work instead).

The district court granted summary judgment against the plaintiff. ${ }^{200}$ In an analysis that resembled the approach in Reynolds, the Seventh Circuit affirmed. The court of appeals first considered Scott's hostile work environment claim, and began by citing approvingly the EEOC guidelines' definition of harassment as "conduct of a sexual nature."201 More subtly, the court trivialized Scott's experience by comparing it to a situation involving sexual advances: "Scott admitted in her deposition [that] Gadberry never explicitly asked her to have sex and never touched her. . . Additionally, there is no evidence of Gadberry becoming bitter due to Scott's refusal to entertain his advances." 202 Measured against this standard, and severed from Scott's allegation that the automotive department's failure to take her seriously had led them to deprive her of appropriate training, the conduct of the male mechanics appeared relatively inconsequential. The appellate court therefore had little difficulty affirming the conclusion that the "sexual" harassment was not sufficiently severe or pervasive to establish a hostile work environment. ${ }^{203}$

Scott's complaint of inadequate training also escaped review under a disparate treatment analysis. The court did not analyze Scott's training allegation as a separate claim, but mentioned it only in connection with her

197. 798 F.2d 210 (7th Cir. 1986).

198. Id. at 211.

199. Id.

200. See Scott v. Sears, Roebuck \& Co., 605 F. Supp. 1047 (N.D. IIl. 1985), aff'd, 798 F.2d 210 (7th Cir. 1986).

201. Scott, 798 F.2d at 213 (citing 29 CFR § 1604.11(a) (1985)).

202. Id. at $212-14$

203. See id. at 213-14. 
discriminatory discharge claim. ${ }^{204}$ In response to Scott's contention that any low productivity on her part was attributable to Sears's lack of training, the court concluded simply that the "argument does not cut in her favor." 200 The court's attempted explanation was circular: Scott's claim of inadequate training did not excuse her lower productivity, said the court, because Sears had "a legitimate business purpose in terminating the underproductive . . Scott."206 Yet Scott had alleged that her apparent underproductivity was the result of the discriminatory training and harassment. The court's approach allowed it to avoid inquiring into this allegation. For purposes of Scott's hostile work environment claim, the court disregarded the alleged denial of training because it was not sexual in nature. For purposes of the discriminatory firing claim, the court disregarded the sexual overtures and what they may have signaled about the seriousness with which Scott's coworkers took their responsibility to train her.

In fact, the court disregarded evidence suggesting that the company's motives may have been less than pure. Sears did not dispute that Scolt's department manager, in discharging her, had commented that "he didn't want to pay a woman $\$ 7$ an hour when he could get a man to do three brake jobs for that."207 This comment suggested that the manager held a stereotyped preconception of Scott as inherently less competent-and hence worth less in wages - than a man. What is more, the comment suggested that Sears was willing to employ Scott (and her female coworker) only so long as CETA was footing the bill; when that funding ended, the woman's worth was cast in a different light. Despite these implications, the court dismissed the comment as an "isolated statement" that was "insufficient in itself to indicate Scott was wrongfully terminated due to her sex."208

As in Reynolds, Scott's disaggregation worked to the plaintiff's disadvantage by portraying each challenged event as an isolated and relatively innocuous incident. Had the court put all the pieces together, Scott's story, like Reynolds's, would have emerged as familiar examples of the problems frequently experienced by women in the trades: They are rarely taken seriously as workers, and they are harassed in myriad ways in order to remind them that even though they are doing a "man's job," they are still "different" and less competent. $^{209}$

204. The court's opinion does not reveal whether Scolt alleged Sears's failure to extend her adequale training and opportunity to do brake work was a separate form of disparate treatment. See $1 d$. al 211 .

205. Id. at 214 .

206. Id. at 215 .

207. Id. at 212 .

208. Id. at 215. Indeed, the court went even further, suggesting that if Sears had retained Scott over a more productive male mechanic, Sears would have opened itself up to a charge of reverse diserimination. See id.

209. See MARY MARTIN, HARD-HATTED WOMEN: STORIES OF STRUGGLE AND SLCCESS IN THE TRADES 10 (1988) ("II addition to sexual advances, women in the trades] also face another pervasive and sinister kind of harassment which is gender-based, but may have nothing to do with sex. It is harassment 
This dynamic also occurs in white-collar settings. ${ }^{210}$ In such settings, courts may have even more difficulty comprehending the significance of nonsexual harassment. We have already seen how the court in King v. Board of Regents of the University of Wisconsin System failed to perceive the importance of nonsexual actions taken against an assistant professor, even though it easily found sexual advances against her to be actionable. ${ }^{211}$ Ross v. Double Diamond, Inc. ${ }^{212}$ provides a second illustration. Sheila Stoudenmire was hired as a salesperson for Double Diamond, a company that developed and sold property in a Texas lakeside community. During Stoudenmire's interview, the manager, Larry Womack, told her he was looking for a part-time receptionist and secretary; Stoudenmire recommended her younger sister, Beverly Ross. Womack hired Ross, and during her first hour on the job, began to subject her to unwelcome sexual advances. He asked her if she "fooled around," lined her up against a wall and told her to pull up her dress so he could take her picture, and asked her to "pant" for him on the telephone. ${ }^{213}$ Later that evening, in a meeting with a group of salespeople, Womack stood by while one of the men took a picture up Ross's dress. The next day, Womack pulled Ross onto his lap and refused to let her go until someone else entered his office. Later, after she refused an order to "bend over" and clean up some mustard on the wall, he trapped her against the closed door of his office. ${ }^{214}$ The next day, Ross, Stoudenmire, and another female salesperson complained about Womack's actions to the local sheriff. The sheriff told them there was nothing he could do, but advised them that they could complain to Womack's boss, to the district attorney, or to the EEOC.

During this period, Stoudenmire was training as a salesperson. Before Stoudenmire went to the sheriff, Womack had made only one unseemly overture to her, commenting that "he bet she liked to wear black boots and carry a whip in the bedroom." 215 After going to see the sheriff, Stoudenmire approached Womack's boss, Robert Gray, to complain about Womack. ${ }^{216}$ Gray confronted Womack. Womack subsequently berated Stoudenmire for going over his head and went after her by making it difficult for her to

aimed at us simply because we are women in a 'man's' job, and its function is to discourage us from staying in our trades."); SCHROEDEL, supra note 16, at xiv-xv ("[T] here is one theme which is so universal, so pervasive, that it cuts across all accounts [from women in the trades]. That is the theme of sex discrimination in its multitude of forms.").

210. See Vicki Schultz, Telling Stories About Women and Work: Judicial Interpretations of Sex Segregation in the Workplace in Title VII Cases Raising the Lack of Interest Argument, 103 HARV. L. RBV. $1750,1835-36$ (1990) (analyzing the core features of hostile work environments that confront women in male-dominated work settings, including white-collar ones).

211. See supra Section I.C.

212. 672 F. Supp. 261 (N.D. Tex 1987).

213. Id. at 271 .

214. Id. at 265.

215. Id.

216. See id. at 266. 
complete her training: "Womack required Stoudenmire to continue her studying as a sales trainee in a separate room, away from the male trainees. In addition, Stoudenmire could not take her training material home at the end of the day. She had been allowed to take the material home in the past."217 A few days later, when Stoudenmire showed up for work, Womack told her that Ray Wylie, the vice president of sales, wanted to speak to her on the telephone. Wylie told her that she was "barking up the wrong tree" and that "we know how to handle girls like you." 218 He threatened that if she pursued the matter any further "she would lose her home and [her] husband would lose his job." 119 He also threatened to "say that she tore off her blouse . . . and tried to have Gray make love to her if she 'did anything about' the... harassment." ${ }^{.220}$ Womack fired Stoudenmire and Ross later that day when, after calling the sheriff about Wylie's threats, they left without permission.

The court's analysis of the two sisters' hostile work environment claims reveals the influence of the sexual desire-dominance paradigm. The court's discussion of the relevant precedent singled out sexual advances as the most troubling type of harassment. ${ }^{22 !}$ Against this backdrop, the court had no difficulty finding that Ross's mistreatment constituted actionable harassment. The court relied on the fact that Ross was an innocent, young woman who had been subjected to sexual advances by an older, more powerful male supervisor. ${ }^{222}$ Indeed, the court's description of the harassment emphasizes the extent to which a modest young woman like Ross would experience humiliation and shame at the hands of experienced sexual predators like Womack and the other men:

The Court is mindful that the sexual abuse began on Ross' very first day on the job. Along with the general insecurity and awkwardness that accompanies anyone's first day on the job, Ross was forced to deal with the lewd comments and actions of her superiors. . . Ross did nothing to provoke or encourage such a comment. Womack had just met Ross for the first time. ...

During the same morning, Womack forced Ross into another uncomfortable situation by telling her to pull up her dress so that he could take a picture of her. Ross stated that she was scared of Womack ... and tried to pacify [him] while retaining her dignity by just pulling the dress up two inches to her knees....

217. Id.

218. Id.

219. Id.

220. Id. at 275 (quoting Ray Wylie).

221. See id. at 269-70 (reviewing Henson v. City of Dundee, 682 F.2d 897 (11th Cir. 1982), and Bundy v. Jackson, 641 F.2d 934 (D.C. Cir. 1981), and emphasizing the fact that the plantiffs' supervisors pressured them to have sexual relations).

222. See id. at 271. 
... The torment which Ross experienced continued.... Womack refused to give [this picture and the other picture taken up Ross's dress by one of the salesmen] to Ross and refused to even allow Ross to see the pictures. This caused Ross great torment. She did not know how revealing the picture was that the salesman took up her dress. ...

...

... In addition, many of [Womack's and the other harassers'] victims were young, between the ages of seventeen and twenty three. The plaintiffs were twenty and twenty three years old. However, the [men] who committed the acts were in their thirties or forties. This type of situation lends itself to a finding that there was an abusive work environment. ${ }^{223}$

In contrast to this extended analysis of Ross's horror and degradation, the court refused even to speculate about how Stoudenmire felt about her mistreatment. With notable lack of passion, the court dryly recounted the incidents of which Stoudenmire complained and concluded in summary fashion: "Title VII is not a shield which protects people from all sexual discrimination. The type of conduct listed above does not rise to the level of harassment which is actionable. It is not sufficiently severe or pervasive to alter the conditions of employment or create an abusive work environment.",224

From the tone of the opinion, it seems clear that a number of facts blinded the court to the harm of the hostile and sexist gestures directed at Stoudenmire. Stoudenmire's mistreatment did not consist of sexual advances and other conduct the court could recognize as shame-inducing; Stoudenmire presented herself with an assertiveness that prevented the court from seeing her as a hapless victim of worldly predators; and she had attempted to join Double Diamond as a competitor to the men in the salesforce, unlike Ross who had taken a job as an underling to Womack and the other men. "From viewing the witnesses on the stand," observed the court, "this Court finds that Stoudenmire was much more assertive than Ross. Stoudenmire is Ross' older sister, and she was resolved to protecting both herself and Ross."225

Although Stoudenmire won on her retaliation claim, the court missed an opportunity to understand her mistreatment as sex-based harassment. That

223. Id. at 271-72.

224. Id. at 273 (citations omitted).

225. Id. at 276. There are many other cases in which the plaintiff's failure to conform to the court's image of a proper victim hurt the plaintiff's case. See, e.g., Kirkland v. Brinias, 741 F. Supp. 692, 694 (E.D. Tenn. 1989) ("Both waitresses were married women with years of waitressing experience who were quite able to take care of themselves."), aff'd, 944 F.2d 905 (6th Cir. 1991); Perkins v. General Motors Corp., 709 F. Supp. 1487, 1496 (W.D. Mo. 1989) ("Perkins is not the downtrodden victim she attempted to portray throughout the trial; Perkins is an intelligent, articulate, aggressive, ambitious, tough and friendly person who has good people skills. She was and is a strong person, well able to fend for and defend herself."), aff'd in part and rev'd in part sub nom. Perkins v. Spivey, 911 F.2d 22 (8th Cir. 1990), discussed infra text accompanying notes 242-244. 
Stoudenmire's situation strayed too far from the sexual desire-dominance paradigm prevented the court from perceiving that Womack's campaign to undermine her ability to pursue her chosen career alongside her male colleagues was as harmful to her aspirations-and to the larger aspiration of integrating women into the workforce as full equals-as the more familiar sexual abuse experienced by her sister.

\section{Sexual Paternalism and the Unwelcomeness Requirement}

Ross v. Double Diamond exemplifies another, related problem engendered by the sexual desire-dominance paradigm. By focusing on sexual advances as the quintessential harassment, the paradigm encourages courts to extend protection to women for the wrong reasons. Rather than emphasizing the use of harassment law to promote women's empowerment and equality as workers, it subtly appeals to judges to protect women's sexual virtue or sensibilities.

This sexual paternalism is deeply conservative; its benefits are limited to women imagined to possess the sexual purity that renders them deserving of protection. Such protection historically has been reserved for white, middle-class women who did not upset the settled gender order by abandoning the domestic sphere for wage work or politics. ${ }^{226}$ Contemporary case law sometimes reproduces this legacy by requiring plaintiffs to conform to the image of the "good victim" if they are to receive legal protection. Ross $v$. Double Diamond suggests that, in the eyes of some judges, even being an older, married woman who aspires to a male-dominated occupation is sufficient to remove a woman from the court's protection.

The courts' application of the requirement that sexual harassment be "unwelcome" provides an even clearer illustration of this exclusionary dynamic.

226. See DuBois \& Gordon, supra note 46, at 39 (characterizing as conservative some aspects of 19thand early 20th-century feminism in the social purity tradition: "Social purity feminists not only accepted a confining sexual morality for women, but they also excluded from their sisterhood women who did not or could not go along"); Paula Giddings, The Last Taboo, in RACE-INC JUSTICE, EN-GENDERING POWER: ESSAYS ON ANITA HILl, ClaRENCE ThOMAS, AND THE CONSTRUCTION OF SOCIAL REALTT 441, 443-5I (Toni Morrison ed., 1992) (noting the value that 19th-century intellectuals placed on women who "did not tempt" and their belief that lower-class women were immoral because they worked outside the home). As Christine Stansell notes:

Within the propertied classes, women constituted themselves the moral guardians of their families and their nation, offsetting some of the inherited liabilities of their sex. Laboring women were less fortunate: The domestic ideals from which their prosperous sisters profited did little to lighten the oppressions of sex and class they suffered. They were also more troublesome, since their actions-indeed, their very existence as impoverished female workers-violated some of the dearest held genteel precepts of "woman's nature" and "woman's place."

Christine Stansell, CTy of Women: Sex and Class IN New York, 1789-1860 at xi (Illini Books 1987) (1986).

227. Under the EEOC guidelines and the dominani legal paradigm, harassment is defined as "[ $u]$ nwelcome sexual advances, requests for sexual favors, and other vertal or physical conduct of a sexual nature." EEOC Guidelines on Discrimination Because of Sex. 29 C.F.R. $\S 1604.11$ (a) (1997) (emphasis added). 
Reed v. Shepard, ${ }^{228}$ for example, involved a woman who worked as a civilian jailer. Her position was created by the sheriff's department in 1976 as a step down from the male-only deputy sheriff position, allegedly for the purpose of conserving funds. In addition to alleging the "customary complaints concerning discrimination in pay, promotion and benefits," Reed alleged that she was discriminatorily denied locker and restroom facilities and that "she was required to perform onerous duties in addition to ... tasks relating to the management of the jail."229 These claims were consigned to a separate disparate treatment analysis. For purposes of the hostile work environment claim, the Seventh Circuit focused on the behavior of Reed's male coworkers:

"Plaintiff contends that she was handcuffed to the drunk tank and sally port doors, that she was subjected to suggestive remarks ...., that conversations often centered around oral sex, that she was physically hit and punched in the kidneys, that her head was grabbed and forcefully placed in members' laps, and that she was the subject of lewd jokes and remarks. She testified that she had chairs pulled out from under her, a cattle prod with an electrical shock was placed between her legs, and that they frequently tickled her. She was placed in a laundry basket, handcuffed inside an elevator, handcuffed to the toilet and her face pushed into the water, and maced."230

The Seventh Circuit's analysis simultaneously professed its own horror at Reed's coworkers' activities and placed Reed herself outside the community of women deemed capable of being harmed by such horrific treatment: "By any objective standard, the behavior of the male deputies and jailers toward Reed ... was ... repulsive. But apparently not to Reed." ${ }^{\text {"231 }}$ The court reached this conclusion based on evidence that Reed used profanity, told off-color jokes, engaged in sexual horseplay and flirting, and failed to wear a bra underneath her T-shirt. ${ }^{232}$

Whether Reed participated in sexualizing the atmosphere because she felt pressure to do so in order to be accepted, as she testified, ${ }^{233}$ or even because she enjoyed contributing to the sexual ribaldry, the court could have concluded that Reed's behavior justified her coworkers' conduct only by viewing the case through the lens of sexual paternalism. For even if Reed displayed a sense of bawdy sexuality—or, to go even further, even if she had "welcomed the sexual hijinx [sic] of her co-workers"234-this in no way implied that she had invited nonsexual violent physical assaults, such as being hit and punched in

228. 939 F.2d 484 (7th Cir. 1991).

229. Id. at 486.

230. Id. (footnote omitted) (quoting from the district court's unpublished opinion).

231. Id.

232. See id. at $486-87$.

233. See id. at 492 .

234. Id. 
the kidneys, shocked with a cattle prod, or pushed facedown into the toilet. Yet, in the court's eyes, Reed's own conduct had branded her as a bad girl outside the bounds of legal protection. Indeed, the coun stressed that "other female employees testified that the male jail employees did not behave in this manner around women who asked them not to."235

Other courts have rejected the claims of women who appeared to them to be too bawdy, too worldly, too old, or too strong to need sexual protection. In Weinsheimer v. Rockwell International Corp., ${ }^{236}$ for example, the court concluded that a female thermal protection inspector, whose job involved evaluating the work of plant technicians, had welcomed a series of abusive acts by a male technician. The technician had held a knife to her throat, shoved her into a file cabinet, threatened to bang her head into the ground, and grabbed her pelvic area and breasts. Because the victim had engaged in sexual banter and joking and had used "abusive and vulgar language" in speaking to her boyfriend on the telephone at work, however, the court concluded that the technician's treatment was not actionable harassment. ${ }^{237}$ In Kirkland $v$. Brinias, ${ }^{238}$ the court ruled against two waitresses who had been repeatedly abused by a fifty-year-old male busboy who warned that he would not take orders from a woman. The busboy had sexually propositioned and groped the waitresses, in addition to hitting, kicking, and threatening them. The court found "that [although] some misconduct was of a sexually offensive nature, that would create a hostile and intimidating working environment for a reasonable person ...., there is no hint that it had any harmful psychological effect on the plaintiffs." 239 Apparently, the court based this finding on the fact that the plaintiffs were "both capable, outspoken women," $2 \pm 0$ indeed, "married women with years of waitressing experience who were quite able to take care of themselves." 241

Similarly, in Perkins v. General Morors Corp. ${ }^{2.22}$ the court rejected a challenge of both nonsexual conduct and sexual misconduct (including rape) with the observation: "Perkins is not the downtrodden victim she attempted to portray throughout the trial; Perkins is an intelligent, articulate, aggressive, ambitious, tough and friendly person who has good people skills. She was and is a strong person, well able to fend for and defend herself." ${ }^{.2+3}$ As the cour bluntly stated, "The... conduct about which Perkins complains was

235. Id.

236. 754 F. Supp. 1559 (M.D. Fla. 1990), aff'd, 949 F.2d 1162 (1/th Cir. 1991).

237. Id at 1565 .

238. 741 F. Supp. 692 (E.D. Tenn. 1989), aff'd, 944 F.2d 905 (6th Cir. 1991)

239. Id. at 698 .

240. Id.

241. Id. at 694.

242. 709 F. Supp. 1487 (W.D. Mo. 1989), aff'd in part and rev'd in part sub nom. Petkıns v. Spivey. 911 F.2d 22 (8th Cir. 1990).

243. Id. at 1496. 
welcomed and encouraged by her. [She] was an active and encouraging participant in sexually explicit conversation and actions."244

To conform to the image of the proper victim, women must comport themselves as sexually pure, even passive, beings who have been violated by their coworkers' sexual predation. This requirement is not only sexist, but also class-biased in nature, for working-class women are less likely than more privileged women to be perceived as pure; and they may even be more likely than other women to engage in the sexual give-and-take with their male colleagues that courts deem to strip women of their virtue. ${ }^{245}$ Regardless of their backgrounds or their underlying motivations, women who participate in sexual joking and ribaldry become fallen women, no longer capable of finding harassment unwelcome-even when that harassment consists of nonsexual actions with the purpose of driving them away from the job or undermining their competence or authority on the job. Within the sexual desire-dominance paradigm, the focus on protecting women from sexual violation deflects attention away from such nonsexual assaults on their capabilities as workers.

\section{E. The McKinney Rule and Its Lack of Influence}

At a formal level, the judicial emphasis on sexuality is surprising. Even though the EEOC guidelines focus on sexual conduct, the EEOC has long recognized that nonsexual, gender-based harassment may violate Title VII. ${ }^{246}$ Even more importantly, there is nothing in the language or purpose of the statute itself that requires or intimates an emphasis on sexual conduct.

244. Id. at 1498.

245. I am grateful to the late Markie Rath for helping me see this point. For historical support, sec, for example, STANSELL, supra note 226 , passim.

246. Early EEOC compliance manuals recognized that harassment need not be sexual in nature to constitute sex discrimination in violation of Title VII. See EEOC Compl. Man. (CCH) $\$ 615.6,93105$, at 3217 (Jan. 1982) ("Sexual harassment is one type of harassment based on sex. However, it is not the only type of unlawful harassment which is sex-based or which stems from sex discrimination."). Subsequent statements of policy guidance confirmed the point. See EEOC Policy Guidance on Current Issues of Sexual Harassment, Daily Lab. Rep. (BNA) No. 60, at E-1 (Mar. 28, 1990) ("Although the Guidelines specifically address conduct that is sexual in nature, the Commission notes that sex-based harassment-that is, harassment not involving sexual activity or language-may also give rise to Title VII liability (just as in the case of harassment based on race, national origin or religion) if it is 'sufficiently patterned or pervasive' and directed at employees because of their sex." (citations omitted)).

More recently, the EEOC issued proposed guidelines that would have, among other things, confirmed and clarified the illegal nature of nonsexual, gender-based harassment. See Guidelines on Harassment Based on Race, Color, Religion, Gender, National Origin, Age, or Disability, 58 Fed. Reg. 51,266, 51,267 n.2 (1993) (to be codified at 29 C.F.R. \& 1609) (proposed Oct. 1, 1993) ("Although the Commission has always recognized that gender-based harassment is actionable, the Guidelines on Discrimination Because of Sex describe only conduct of a sexual nature. These proposed guidelines simply state the applicable rule in guideline form."). Due to political pressure from conservative religious groups who objected to the proposed guidelines' treatment of religious harassment, the EEOC ultimately withdrew the proposed 1993 guidelines. See Withdrawal of the Proposed Guidelines, 59 Fed. Reg. 51,396 (1994) (10 be codified at 29 C.F.R. § 1609); see also Religious Harassment Rules Shelved, L.A. TIMES, Sept. 21, 1994, at A17. 
Some courts of appeals have recognized this point. In 1985, in McKinney v. Dole, ${ }^{247}$ the Court of Appeals for the District of Columbia Circuit concluded that harassment need not take the form of "sexual advances or of other incidents with clearly sexual overtones."248 The cour held that "any harassment or other unequal treatment of an employee or group of employees that would not occur but for the sex of the employee or employees may, if sufficiently patterned or pervasive, comprise an illegal condition of employment under Title VI." "249 In the wake of McKinney's 1985 pronouncement, other appellate courts issued similar statements, some more than a decade ago. ${ }^{250}$

But McKinney has had little influence on the law. Many courts of appeals have simply ignored the case. In these circuits, courts continue to define harassment as unwelcome "sexual advances, requests for sexual favors or other verbal or physical conduct of a sexual nature." conduct they do not consider sexual from the hostile work environment claim and to consider it, if at all, only under a separate disparate treatment claim. ${ }^{252}$

\footnotetext{
247. 765 F.2d 1129 (D.C. Cir. 1985).

248. Id at 1138 .

249. Id.
}

250. The First, Third, Seventh. Eighth. Tenth, Eleventh, and Federal Circuits have made such pronouncements. See Lipsett v. University of Puerto Rico, 864 F.2d 881, 90 (Isi Cir. 1988) (relying on McKinney to conclude that a "constant verbal attack [on surgery residents]. one whuch challenged their capacity as wormen to be surgeons ... although not explicitly sexual, was nonetheless charged with anti-female animus, and therefore could be found to have contributed significantly to the hostile environment"); Andrews v. City of Philadelphia, 895 F.2d 1469, 1485 (3d Cir. 1990) (holding that hostile work environment harassment "is not necessarily required to include sexual overtones in every instance" but may also include "pervasive use of derogatory and insulting terms relating to women generally and addressed to female employees personally" as well as the "posting of [pomography] in common areas and in the plaintiff's personal work spaces"); Doe v. City of Belleville. 119 F.3d 563, 575 (7th Cir. 1997) (acknowledging that "harassment lacking in sexual overones may nonetheless suppon a claim for sex discrimination when it is visited upon workers of one gender but not the other"); Hall v. Gus Constr. Co., 842 F.2d 1010, 1014 (8th Cir. 1988) (relying on McKinney to conclude that "[i]ntimidation and hostility toward women because they are women can . . . result from conduct other than explicit sexual advances"): Hicks v. Gates Rubber Co., 833 F.2d 1406, 1415 (10th Cir. 1987) (relying on McKinney to conclude that threats of physical violence and vertal abuse should be considered for purposes of a hostile work environment claim); Bell v. Crackin Good Bakers, Inc., 777 F.2d 1497, 1503 (1lth Cir. 1985) (holding that sexual harassment need not involve "unwelcome sexual advances." but may also consist of "threatening. bellicose, demeaning, hostile or offensive conduct by a supervisor in the workplace because of the sex of the victim"); King v. Hillen, 21 F.3d 1572, 1583 (Fed. Cir. 1994) (holding that hostile work environment harassment need not be of a sexual nature so long as the conduct is based on the victim's sex).

251. E.g., Yeary v. Goodwill Indus.-Knoxville, 107 F.3d 443, 445 (6th Cir. 1997) (requiring the plaintiff to show that she was "'subjected to unwelcomel] sexual harassment in the form of sexual advances, requests for sexual favors or other vertal or physical conduct of a sexual nature"." (quoting Rabidue v. Osceola Ref. Co., 805 F.2d 611,619-20 (6th Cir. 1986)) (alteration in original)); accord Mattem v. Eastman Kodak Co., 104 F.3d 702, 706 (5th Cir. 1997); see also Fuller v. City of Oakland, 47 F.3d 1522,1527 (9th Cir. 1995) (requiring the plaintiff to show that "she was subjected to vertal or physical conduct of a sexual nature"); Cosgrove v. Sears, Roebuck \& Co., 9 F.3d 1033, 1042 (2d Cir. 1993) (requiring the plaintiff to show she was the subject of "unwelcome advances," without explicitly stating that they must be sexual).

252. See, e.g., Gleason v. Mesirow Fin., Inc., 118 F.3d 1134 (7th Cir. 1997): DeAngelis v. El Paso Mun. Police Officers Ass'n, 51 F.3d 591 (5th Cir. 1995): Rabidue. 805 F.2d 611 (6th Cir. 1986): Hunt-Golliday v. Metropolitan Water Reclamation Dist., No. 94-C-3559. 1994 U.S. Dist. LEXIS 17318. at *4-5, *17-18 (N.D. Ill. Dec. 6, 1994); Anderson v. Chicago Hous. Auth., No. 86-C-0449, 1988 U.S. Dist. 
King v. Board of Regents of the University of Wisconsin System, ${ }^{253}$ Scott $v$. Sears, Roebuck \& Co. ${ }^{254}$ Ross v. Double Diamond, Inc. ${ }^{255}$ as well as the lower court's decision in Harris v. Forklift Systems, Inc., ${ }^{256}$ were all decided after McKinney.

Even in some of the circuits that have adopted the McKinney rule, subsequent cases have ignored or undermined it. Without discussion, some judges have simply considered only sexual conduct for purposes of the hostile work environment claim and relegated any nonsexual misconduct to a separate disparate treatment analysis or disregarded it altogether. ${ }^{257}$ Such an approach subverts the spirit of the McKinney rule, as a pair of cases from the Tenth Circuit illustrates.

In 1987, the Tenth Circuit adopted the McKinney rule in Hicks v. Gates Rubber Co. ${ }^{258}$ Three years later, in Ramsey v. City of Denver, ${ }^{259}$ the court undermined the McKinney and Hicks reasoning by affirming the lower court's disregard of nonsexual harassment. Ramsey was a municipal engineer who was subjected to a familiar pattern of sexual and nonsexual treatment to undermine her professional status. James Brown, the director of the traffic division, who hired Ramsey, "was known to believe that certain jobs were more suitable for women than others." 260 Ramsey claimed that upon being hired, she was given inadequate supervisory assistance and inappropriate assignments. Her most immediate supervisor Mitchell, for example, allegedly asked to be relieved of supervising her, "due to his not getting along with her." ${ }^{261}$ She was also assigned to supervise a man named Jurado, whom she characterized as an "overt sexist." her supervisory duties over him. In addition, Ramsey charged that she was subjected to "comments, drawings, sexually-charged physical conduct, and publications found in the work area." 263 Eventually, the city extended her probation rather than making her a permanent employee, and she resigned.

The analysis by the court of appeals embodied the typical disaggregation approach. For purposes of Ramsey's hostile work environment claim, the court

LEXIS 14454 (N.D. Ill. Dec. 20, 1988); Keziah v. W.M. Brown \& Son, Inc., 683 F. Supp. 542 (W.D.N.C. 1988), rev'd on other grounds, 888 F.2d 322 (4th Cir. 1989); Loftin-Boggs v. City of Meridian, 633 F. Supp. 1323 (S.D. Miss. 1986), aff'd, 824 F.2d 971 (5th Cir. 1987).

253. 898 F.2d 533 (7th Cir. 1990), discussed supra Section I.C.

254. 798 F.2d 210 (7th Cir. 1986), discussed supra notes 197-209 and accompanying text.

255. 672 F. Supp. 261 (N.D. Tex 1987), discussed supra text accompanying notes 212-225.

256. 60 Empl. Prac. Dec. (CCH) 42,070 (M.D. Tenn. 1990), aff'd, 976 F.2d 733 (6th Cir. 1992) (per curiam), rev'd, 510 U.S. 17 (1993), discussed supra Section II.A.

257. See, e.g., Ramsey v. City of Denver, 907 F.2d 1004 (10th Cir. 1990); Graham v. American Airlines, Inc., 731 F. Supp. 1494 (N.D. Okla. 1989); Sanchez v. City of Miami Beach, 720 F. Supp. 974 (S.D. Fla. 1989); Sapp v. City of Warner Robins, 655 F. Supp. 1043 (M.D. Ga. 1987).

258. 833 F.2d 1406, 1415 (10th Cir. 1987).

259. 907 F.2d 1004 (10th Cir. 1990).

260. Id. at 1008 .

261. Id. at 1009 .

262. Id.

263. Id. at 1006. 
considered only the comments, drawings, suggestive physical gestures, and "publications."264 Having severed the few overtly sexual incidents of harassment from the larger discriminatory context, the court of appeals held in conclusory fashion that the sexual conduct was not sufficiently severe or pervasive to constitute an actionable hostile work environment. ${ }^{265}$ The court analyzed the nonsexual actions as disparate treatment and ruled against Ramsey on the ground that she failed to prove that they occurred because of her sex. The court refused to consider as direct evidence of discrimination the director's statement that her job was inappropriate for women-even though the director confirmed at trial "his feelings about women being better suited to some jobs than to others." 266 According to the court, Ramsey failed to show that the director's attitude was connected to her supervisors' refusal to work with her or her assignment to work with a sexist colleague. Instead, the court accepted the traffic division's allegation that Ramsey brought all her problems on herself because she lacked "interpersonal skills."267 Thus, it was Ramsey's personality, rather than her sex, that accounted for her mistreatment.

As a technical matter, it may be possible to square the Tenth Circuit's analysis in Ramsey with its earlier adoption of the McKinney rule in Hicks. The Ramsey opinion suggests that the plaintiff may have failed to plead the nonsexual incidents as part of her harassment claim. ${ }^{268}$ Thus, the court did not expressly rule, contrary to Hicks and McKinney, that such incidents could not count toward establishing a hostile work environment. Nonetheless, there is nothing that would have prevented the court of appeals from considering the nonsexual conduct for purposes of evaluating the hostile work environment claim on appeal-or at least directing the trial court to do so on remand. At a minimum, it seems obvious that the director's discriminatory comments should have been considered evidence of a hostile work environment. The court's failure to take such nonsexualized evidence of bias into account violates the spirit, if not the letter, of Hicks and McKinney.

More recently, a number of other courts of appeals have begun to undermine McKinney-while purporting to follow it-through a new route. These courts of appeals (and district courts in these circuits) cite McKinney approvingly for the proposition that nonsexual conduct may be included in a hostile work environment claim. Informally, however, these courts continue to single out sexual advances and other sexually explicit actions as the "real" harassment, concluding that the nonsexual harassment did not occur because of the plaintiff's sex. ${ }^{269}$ Thus, in addition to the severity or pervasiveness

264. Id. at 1006, 1011 .

265. See id. at 1011 .

266. Id. at 1008 .

267. Id. at 1009 .

268. See id. at 1006.

269. See, e.g., Morrison v. Carleton Woolen Mills, Inc., 108 F.3d 429, 439-4l (Ist Cir. 1997); Gross v. Burggraf Constr. Co., 53 F.3d 1531, 1542-46 (10th Cir. 1995): Hicks v. Gates Rubber Co., 928 F.2d 966. 
element, causation has become a key element on which plaintiffs lose hostile work environment claims. Furthermore, some cases apply a heightened causation standard: Rather than requiring plaintiffs to show simple but-for causation-that the harassment occurred because of sex-some courts demand a showing that the harassment was motivated by "gender animus."270 Although evidence of nonsexual misconduct sometimes meets the causation hurdle-particularly, conduct that on its face reveals a derogatory attitude toward women on the job-other nonsexual conduct of the type that is so commonly directed at women by their male coworkers fails to register as gender-based.

Another Tenth Circuit case provides an example of this trend. In Gross v. Burggraf Construction Co., ${ }^{271}$ the court affirmed the grant of summary judgment against a female truck driver on her hostile work environment claim. Patricia Gross worked for a road construction company under the supervision of George Anderson, who had a poor track record working with women: Only two of the forty women who worked under his supervision completed the 1990 construction season. Gross believed Anderson's treatment of her was part of a larger pattern of discrimination. She claimed that Anderson had "subjected [her] to a hostile work environment because she was a "woman working at a man's job." 272 Anderson's conduct did not assume a sexual form. Instead, he humiliated Gross, denigrated her ability, and forced her to submit to abusive authority. In front of Gross's male coworkers, for instance, Anderson repeatedly referred to her as "dumb." ${ }^{.273} \mathrm{He}$ "embarrassed and humiliated her

$972-73$ (10th Cir. 1991); Cobbins v. School Bd., No. 90-1754, 1991 WL 1828, at *4 (4th Cir. Jan. 14, 1991); Weinsheimer v. Rockwell Int'1 Corp., 754 F. Supp. 1559, 1564-65 (M.D. Fla. 1990), aff'd, 949 F.2d 1162 (11th Cir. 1991); Payne v. Children's Home Soc'y, 892 P.2d 1102, 1106-07 (Wash. App. 1995).

270. See, e.g., Lipsett v. University of Puerto Rico, 864 F.2d 881, 905 (1st Cir. 1988) ("This attack, although not explicitly sexual, was nonetheless charged with anti-female animus, and therefore can be found to have contributed significantly to the hostile environment."); Robinson v. Jacksonville Shipyards, Inc., 760 F. Supp. 1486, 1522 (M.D. Fla. 1991) (holding that the plaintiff may prove causation through evidence of "harassing behavior lacking a sexually explicit content but directed at women and motivated by animus against women"); Morris v. American Nat'l Can Corp., 730 F. Supp. 1489, 1496 (E.D. Mo. 1989) (holding that nonsexual incidents were "generated by . . . animus" and therefore cognizable in assessing a hostile work environment claim), aff'd in part and rev'd in part, 952 F.2d 200 (8th Cir. 1991).

Insofar as such cases require plaintiffs to prove gender animus, they are incorrect as a matter of law. It is a long-established principle that Title VII does not require proof of such animosity. Title VII prohibits all differential treatment, whether such treatment is motivated by animosity or by a desire to protect, or even to favor, women. See, e.g., Doe v. City of Belleville, 119 F.3d 563, 583 n.19 (7th Cir. 1997) ("[W]e have expressly rejected the argument that proof of a gender-based animus is required to make a claim of sex discrimination."); King v. Board of Regents of the Univ. of Wis. Sys., 898 F.2d 533, 539 (7th Cir. 1990) ("All that is required is that the action taken be motivated by the gender of the plaintiff. No hatred, no animus, and no dislike is required."); Lenihan v. City of New York, 636 F. Supp. 998, 1009 (S.D.N.Y. 1985) (holding that Title VII does not require sex discrimination plaintiffs to prove animus toward women (citing International Bhd. of Teamsters v. United States, 431 U.S. 324, 335-36 n.15 (1977))); cf. UAW v. Johnson Controls, Inc., 499 U.S. 187, 200 (1991) ("The beneficence of an employer's purpose does not undermine the conclusion that an explicit gender-based policy is sex discrimination under $\$ 703$ (a) [of Titlo VII].").

271. 53 F.3d 1531 (10th Cir. 1995)

272. Id. at 1546 .

273. Id. at 1543 . 
in the presence of other employees" by threatening to fire her if she ruined the transmission on her truck. ${ }^{274}$ On one occasion, as Gross got out of her truck, Anderson yelled: "What the hell are you doing? Get your ass back in the truck and don't you get out of it until I tell you."275 When Anderson could not reach Gross on the company radio, he broadcast to one of her coworkers: "Mark, sometimes, don't you just want to smash a woman in the face?"276 Ultimately, when Anderson heard rumors that Gross was thinking of filing an EEOC charge, he threatened her that "if anyone" were to leave the company, it would be her because of her "bad attitude." $277 \mathrm{He}$ told her that "he could talk to her any way he wanted, regardless of whether it embarrassed or humiliated her in front of her co-workers." 278

The Tenth Circuit's analysis began promisingly: The court's citation of its earlier decision in Hicks acknowledged that harassment need not assume a sexual character. ${ }^{279}$ Yet, even though Anderson's actions amounted to precisely the sort of harassment typically directed at women in the construction trades in an effort to drive them out of the job, ${ }^{280}$ the court of appeals concluded that, as a matter of law, all but one of Anderson's actions were not gender-based. The court considered each incident, one by one, each time dismissing the gender dynamics involved. According to the court, the only potential problem was Anderson's use of the word "ass," a word that, although "vulgar," is "gender neutral" as it "refers to a portion of the anatomy of persons of both sexes."281 Gross also "failed to demonstrate that [Anderson's threat to fire her if she damaged the transmission] was motivated by gender discrimination." 282 Unlike other cases in which women had been called such explicit epithets as "fucking cunt," "bitch," and "whore" and had been told that they were going to be stripped naked to see if they were "real," Gross had not "presented any evidence that [Anderson's] criticism of her driving was sexual or gender-specific." 283 In the court's eyes, even Anderson's admission that he hired Gross only because of federal affirmative action requirements and the undisputed evidence that only two of the forty women who worked under Anderson remained on the job at the end of the season failed to cast a gendered light on Anderson's actions. ${ }^{284}$

274. Id. at 1545 .

275. Id. at 1543 .

276. Id. at 1536 .

277. Id. at 1546 .

278. Id.

279. See id. at 1537 (citing Hicks v. Gates Rubber Co.. 833 F.2d 1406 (10th Cir. 1987)).

280. See, e.g., Peggy Crull, Are Sexual Harassment in Nontraditional and Traditional Workplaces the Same?: Lessons from the Construction Industry (unpublished manuscript presented at the Sex and Power Issues in the Workplace Conference, Bellevue, Washington, Mar. 20-21. 1992) (on file with author).

281. Gross, 53 F.3d at 1537.

282. Id. at 1545 .

283. Id. (distinguishing Steiner v. Showboat Operating Co., 25 F.3d 1459 (9th Cir. 1994); Huddleston v. Roger Dean Chevrolet, Inc., 845 F.2d 900 (1/th Cir. 1988)).

284. See id. at 1543-44. 
In the absence of sexual advances or other core conduct defined as harassment within the sexual desire-dominance model, the Tenth Circuit could not perceive the hostile gender dynamics of Gross's workplace. ${ }^{285}$ Other courts similarly have failed to perceive nonsexual forms of hostility against women as gender-based. The invisibility of the gender-based character of such harms is apparent in judicial decisions on causation, as the next part demonstrates more fully.

\section{THE INVISIBILITY OF GENDER AT WORK}

From the beginning, the question of causation-whether the alleged misconduct occurred "because of sex"-has been a central issue in harassment law. As we have seen, early quid pro quo decisions concluded that sexual overtures occurred because of sex by presuming that such advances were driven by sexual desire. ${ }^{286}$ A male supervisor's heterosexuality supplied an inference that he would not have made such advances toward a man (or a female supervisor toward a woman); a supervisor's homosexuality would supply a corresponding inference that he would not have made advances toward a person of the opposite sex.

Before harassment emerged as a recognizable cause of action, however, there was little or no recognition that sexuality could form the basis for sex-based discrimination. The Title VII inquiry was always: Did the alleged misconduct occur because of sex (or gender)? Outside the realm of harassment, Title VII's traditional focus has been to prohibit employer policies and practices that treat workers differently based on gender-based expectations of who men and women are supposed to be. The Supreme Court's decision in Price Waterhouse v. Hopkins, ${ }^{287}$ which construed Title VII to forbid employers from incorporating into the criteria for successful job performance preconceived notions of suitable feminine or masculine behavior, ${ }^{288}$ provides clear support for this proposition. Price Waterhouse was the logical culmination of earlier law; the thrust of most major developments in Title VII sex discrimination jurisprudence has been toward dismantling employers' settled understandings of appropriate work roles for men and women. ${ }^{289}$

285. Indeed, in the court's eyes, only Gross's statement about "want[ing] to smash a woman in the face" was gender-based because it reflected "hostility toward women." Id. at 1547 . This suggests that the court had silently converted the McKinney and Hicks burden of proving that gender was the but-for cause into a higher hurdle of showing that the harassment was motivated by animus or hatred toward women.

286. See supra Subsection I.B.2.

287. 490 U.S. 228 (1989).

288. See id. at 250-51.

289. For present purposes, a few examples suffice. By construing Title VII to prohibit employers' attempts to bar women from traditionally male-dominated jobs, for instance, courts prevent managers from imposing on workers gender-based expectations of what types of work men and women are supposed to do. See, e.g., Dothard v. Rawlinson, 433 U.S. 321, 333 \& n.17, 335 \& n.21 (1977); Diaz v. Pan Am. World Airways, Inc., 442 F.2d 385, 388 (5th Cir. 1971). By interpreting Title VII to prohibit employers' attempts 
With harassment law, this traditional focus has shifted. Over time, and ironically, the courts have cast sexuality to the foreground and consigned gender to the background. Harassment cases have highlighted the harm of conduct considered sexual, while the larger gender-based processes once deemed the principal focus of Title VII have faded from view. As a result, this part shows, judges often fail to perceive the gender-based quality of the actions through which male workers create environments that sustain their definition of masculine competence-to the detriment of women, who are defined as incapable of such competence.

\section{A. The Two-Tiered Structure of Causation}

Even though the McKinney v. Dole line of cases acknowledged that conduct need not be sexual in content to constitute a hostile work environment, it did not provide a serious break with the assumptions of the sexual desiredominance paradigm. Indeed, even courts that approved McKinney have continued to treat sexual advances as the quintessential sex-based conduct: Borrowing from the quid pro quo harassment model, the courts have presumed that sexual advances (at least when made by a man upon a woman) are based on sex. Yet, when presented with evidence of nonsexual misconduct, judges have tended to miss any harmful gender dynamics involved. This trend has served to accentuate the analytical separation of sexual hostile work environment harassment from nonsexualized disparate treatment that McKinney promised to dissolve.

In Henson v. City of Dundee, ${ }^{290}$ an influential early case, the Eleventh Circuit discussed the different standard of proof needed to establish causation in a hostile work environment harassment case as opposed to an ordinary disparate treatment case. In disparate treatment litigation, the focus is on "'the elusive factual question of intentional discrimination""'29! - whether the adverse treatment occurred because of the plaintiff's sex or instead because of some legitimate nondiscriminatory reason. "In contrast, the case of sexual harassment that creates an offensive environment does not present a factual

to bar fertile women from holding jobs that may threaten the health of their potential fetuses, coures prevent companies from imposing on women the gender-based expectation that future motherhood outweighs the value of their chosen work. See, e.g.. UAW v. Johnson Controls, Inc., 499 U.S. 187 (1991). In fact, by construing Title VII to protect pregnant women's right to hold jobs at all, courts prevent companies from imposing on women the gender-based expectation that being a mother takes procedence over and precludes being a committed worker. See, e.g., Califomia Fed. Sav. \& Loan Ass'n v. Guerra, 479 U.S. 272 (1987). Similarly, by construing Title VII to require employers to justify the use of criteria such as minimum hesght and weight requirements that have a disparate impact on women, cours impose burdens on managers to defend gender-based expectations that only women who are sufficiently tall and heavy to meet the criteria are competent to perform male-dominated jobs such as law enforeement or contections work. See, e.g., Dothard, 433 U.S. at 329-32.

290. 682 F.2d 897 (11th Cir. 1982).

291. Id. at 905 n.11 (quoting Texas Dep't of Community Affairs v. Burdine, 450 U.S. 248, 253-54 n.8 (1981)). 
question of intentional discrimination which is at all elusive. Except in the exceedingly atypical case of a bisexual supervisor, it should be clear that sexual harassment is discrimination based upon sex."292 Indeed, in a hostile work environment case, causation may be presumed: "In the typical case in which a male supervisor makes sexual overtures to a female worker, it is obvious that the supervisor did not treat male employees in a similar fashion." ${ }^{293}$ Thus, following Barnes v. Costle ${ }^{294}$ and other quid pro quo harassment cases, the Henson court's assumption that hostile work environment harassment consists of sexual advances driven by sexual attraction enabled it to presume the existence of causation, which had to be proven in other discrimination cases. This reasoning, which introduced a subtle distinction between hostile work environment harassment and disparate treatment, was endorsed rapidly by other courts. ${ }^{295}$

In fact, the D.C. Circuit accepted such a distinction in McKinney itself. The case was brought by a female budget analyst for the Federal Aviation Administration, who alleged a combination of sexual and nonsexual harassment by her second-line supervisor. After McKinney's boss exposed himself to her, rubbed up against her, and asked her for sexual favors, he forced her to sign a letter agreeing to be laid off without pay. She signed the letter, then dropped it, and he ordered her to pick it up. Instead, she fled into her office, where he followed her. When she tried to escape, her boss "forcefully prevented her from doing so by grabbing her arm and twisting it."296

The D.C. Circuit held that McKinney's timely complaint about this physical assault sufficed to sustain her hostile work environment claim, even if the assault was not driven by sexual motivations. In emphasizing that harassing conduct need not be sexual in character, the court's language stressed that hostile work environment harassment is coterminous with disparate treatment: "[A]ny harassment or other unequal treatment of an employee or group of employees that would not occur but for the sex of the employee or employees may, if sufficiently patterned or pervasive, comprise an illegal condition of employment under Title VII. . . Clearly, then," concluded the court, "if a supervisor consistently uses physical force toward an employee because of that employee's sex, the use of such force may, if pervasive

292. Id.

293. Id. at 904.

294. 561 F.2d 983 (D.C. Cir. 1977), discussed supra text accompanying notes 89-93.

295. In Katz v. Dole, 709 F.2d 251, 255 (4th Cir. 1983), another widely cited hostilc work environment case, for example, the Fourth Circuit stated that "[i]n the usual case involving allegations of disparate treatment, . . . the crux of the matter is ... [whether there was] an intent to discriminate along legally impermissible lines such as race or gender." By contrast, in a hostile work environment case, "the sexual advance or insult" will almost always establish such intent or causation. Id. In the case at hand, concluded the court, the causation "burden was satisfied ... by the showing that Katz was subjected to sustained verbal sexual abuse." Id. at 256 n.7; see also Jones v. Flagship Int'l, 793 F.2d 714, 720 n.5 (5th Cir. 1986) (quoting Henson, 682 F.2d at 905 n.11).

296. McKinney v. Dole, 765 F.2d 1129, 1132 (D.C. Cir. 1985). 
enough, form an illegal 'condition of employment.' . . . In fact, any disparate treatment, even if not facially objectionable, may violate Title VII."297

Although this logic tended to break down the distinctions between hostile work environment harassment and disparate treatment and between sexual and nonsexual conduct, other language in the court's opinion tended to resurrect these distinctions. "It is true," conceded the court, "that proving that a pattern of physical force is illegally discriminatory might be significantly more difficult than proving that a pattern of explicitly sexual advances is illegally discriminatory because the latter are more obviously caused by the sex of the employee." ${ }^{\text {298 }}$ The court did not elaborate on why explicitly sexual advances are "more obviously" based on sex. Given a legal landscape that included Barnes and Henson, however, it seems clear that the court was assuming that sexual overtures are gender-related because they are rooted in sexual desire, while other forms of mistreatment directed at women workers-even at the hands of their male supervisors-are less likely to be rooted in gender. Indeed, one may wonder whether the D.C. Circuit would have had the foresight to extend the concept of hostile work environment harassment to nonsexual conduct if the supervisor's physical assault on the plaintiff had not been the culmination of an earlier pattern of harassment that included sexual overtures.

Subsequent cases have accepted a two-tier structure of causation in which sexually explicit advances are presumed to be sex-based while other problems must be proven to be so. In Andrews v. Ciry of Philadelphia, ${ }^{299}$ for example, the Third Circuit held that conduct other than sexual advances may form the basis for a hostile work environment. "To constitute impermissible discrimination," the court stated, "offensive conduct is not necessarily required to include sexual overtones in every instance ...." So So long as the conduct meets the other criteria for a hostile work environment, an employee need only have "suffered intentional discrimination because of [her] sex." Nonetheless, the court distinguished the probative quality of sexual and nonsexual forms of conduct, just as the courts had in Henson and McKinney:

The intent to discriminate on the basis of sex in cases involving sexual propositions, innuendo, pornographic materials, or sexual derogatory language is implicit, and thus should be recognized as a matter of course. A more fact intensive analysis will be necessary where the actions are not sexual by their very nature. ${ }^{302}$

297. Id. at $1138-39$.

298. Id. at 1139 n.21 (emphasis added).

299. 895 F.2d 1469 (3d Cir. 1990).

300. Id. at 1485 .

301. Id. at 1482 .

302. Id. at 1482 n.3. Other cases hold to this effect. See. e.g. Cline v. General Elec. Credit Auto Lease, 54 Fair Empl. Prac. Cas. (BNA) 419, 423 (N.D. IIl. 1990) ("Implied within the analyses of hostule environment sexual harassment ... is a requirement that the harassment be 'sexual' in nature. . .. If the harassment is unrelated to sexual activity, the question of discriminatory intent reappears."). 
A more recent Third Circuit case, Spain v. Gallegos, ${ }^{303}$ demonstrates how this two-tiered system of causation can lead right back to pre-McKinney reasoning requiring explicitly sexual conduct to establish a hostile work environment. Ellen Spain, a white, female investigator in the Pittsburgh office of the EEOC, claimed that the director of that office, Eugene Nelson, had "a history of passing over her for promotions ... in favor of allegedly lesser qualified male African-American applicants. ${ }^{304}$ After she filed an internal EEOC complaint alleging that the failure to promote her amounted to sex and race discrimination, Nelson "induced her not to proceed with the EEOC complaint by promising that she would receive the next available promotion, so long as she agreed to lend him money periodically. ${ }^{305}$ Nelson continued to extort loans from Spain over the next several years, even though internal EEOC regulations prohibited officials from soliciting or accepting loans from their subordinates. Because these exchanges between Nelson and Spain required private meetings, rumors began to circulate around the office that the two were involved sexually. As a result of these rumors, Spain was ostracized by her coworkers and evaluated negatively by her more immediate supervisors. On the basis of these evaluations, Nelson refused to promote her further. He also refused to try to stop the rumors.

The district court dismissed Spain's hostile work environment claim, and the Third Circuit reversed. The appellate court's analysis began with the statement that "an employee can demonstrate that there is a sexually hostile work environment without proving blatant sexual misconduct." ${ }^{306}$ Under this principle, the court might have concluded that Nelson's extortion of loans from Spain-even without the resulting rumors-provided sufficient evidence of a hostile work environment to survive a motion for summary judgment. The extortion appeared to be gender-based, for Nelson extorted the money by promising to give Spain a deserved promotion that he had withheld because of her sex (and race). Surely it is as discriminatory for a male supervisor to extort money from a female subordinate by withholding a promotion on the basis of her sex as it is for the supervisor to extort sexual favors from a subordinate by threatening to withhold a promotion or other job benefit, as is the case with quid pro quo harassment. In each case, the supervisor uses his power to grant a job benefit in a discriminatory way; he attempts to gain something he would not be able to obtain in the absence of sex discrimination.

Despite the simplicity of such an analysis, the Third Circuit did not adopt it. Instead, the court identified the crux of the hostile work environment harassment claim as Nelson's failure to stop the rumors that he and Spain were having an affair, and strained to characterize the problem as "sexual" as a basis

303. 26 F.3d 439 (3d Cir. 1994).

304. Id. at 442 .

305. Id.

306. Id. at 447 (citing Andrews, 895 F.2d 1469 (3rd Cir. 1990)). 
for concluding that the alleged misconduct was based on Spain's sex. Concluding that "the [causation] element is satisfied because the crux of the rumors and their impact upon Spain is that Spain, a female, subordinate employee, had a sexual relationship with her male superior," 307 the court ignored the fact that the focus of the claim was on Nelson's failure to stop those rumors, which itself was not sexual in content. Apart from that problem, the court's approach required stretching the meaning of the term "sexual" to a breaking point by extending it to cover rumors that two people were having an affair. This necessitated a lengthy defense of why evidence of Nelson's extortion of money from Spain was even relevant for the purpose of shedding light on the resulting rumors.

Why did the court take such a complicated approach to establishing the sex-based nature of the challenged conduct when basing the harassment claim on the extortion itself would have provided a simpler route to this end? The court conceded that the impetus for its approach lay in the two-tier structure of causation established in Andrews:

In reaching our conclusion... we have paid particular attention to the distinction we drew in Andrews between sexual misconduct in which the intent to discriminate "is implicit, and thus should be recognized as a matter of course" and "actions [which] are not sexual by their very nature." . . Accordingly, where an employee claims sex discrimination predicated on sexually neutral conduct it may be necessary for the employee to establish that the employer's motives for its actions were sexual. If the discrimination of which Spain complained was predicated merely on the demands for loans, her case might be of that nature. However, Spain's allegations are not predicated on sexually neutral conduct. Rather, she alleges that the harassment resulted from the rumors that she was having an affair with Nelson. Thus, the harassment directed against her as a woman had a sexual orientation by its very nature. ${ }^{308}$

In this passage, the court returned to the pre-McKinney reasoning it purported to reject. Where a worker seeks to ground a hostile work environment claim on "sexually neutral conduct"-such as her supervisor's extortion of loans in exchange for ceasing discriminatory promotion practices-she must not only prove that the conduct occurred because of her womanhood; she must also prove that the motives for the conduct were "sexual." 309 Thus, sexuality remained the specter haunting the case. The power of the sexual desiredominance paradigm drove the court to look for deep-seated sexual

307. Id. at 448.

308. Id. at 449 (citation omitted).

309. Id. 
motivations, even as it looked right past gender-based considerations that were closer to the surface.

\section{B. Sexuality as a Bright-Line Test for Gender-Based Conduct?}

Why have the courts struggled to define harassment as sexual, as opposed to sex- or gender-based? One possible explanation is that judges believe sexuality provides a bright-line test for delineating when harassment is gender-based. In the absence of clear criteria for determining whether harassment is directed at workers because of their identities as men or women, judges may look to sexual conduct as a proxy.

Although some judges may be seeking such clarity, the emphasis on sexual conduct has not provided a bright-line test for determining whether harassing conduct is based on sex. To begin with, there is no consensus on what counts as sufficiently "sexual." Even Judge Posner, who has thought a great deal about sexuality, ${ }^{310}$ has expressed some uncertainty. "Drawing the line is not always easy," acknowledged the judge:

On one side lie sexual assaults; other physical contact, whether amorous or hostile, for which there is no consent express or implied; uninvited sexual solicitations; intimidating words or acts; obscene language or gestures; pornographic pictures. On the other side lies the occasional vulgar banter, tinged with sexual innuendo, of coarse or boorish workers. ${ }^{311}$

Nor has Judge Posner escaped controversy in applying such concepts. According to Posner, a boss who referred to his secretary as a "pretty girl," made grunting sounds when she wore a leather skirt, commented on how "hot" the office was once she entered, and related that his wife had told him he had "better clean up [his] act" and "think of [his secretary] as Ms. Anita Hill" had not crossed the line to become a "sexual harasser."312 "He never touched the plaintiff," stressed Posner. "He did not invite her . . . to have sex with him, or to go out on a date with him. He made no threats. He did not expose himself, or show her dirty pictures. He never said anything to her that could not be repeated on primetime television." ${ }^{.313}$

As this passage suggests, even though the courts have envisioned sexual advances as the core "sexual" conduct prohibited as sex-based harassment, judges have not been able to agree on what counts as a sexual advance. Like

310. See Richard Posner, SEX AND REASON (1992).

311. Baskerville v. Culligan Int'l Co., 50 F.3d 428, 430 (7th Cir. 1995) (citation omitted).

312. Id. at 430 .

313. Id. at 431; see also Carr v. Allison Gas Turbine Div., Gen. Motors Corp., 32 F.3d 1007, 1010 (7th Cir. 1994) (Posner, C.J.) (noting that physical attacks "are more ominous, more aggressive affronts than mere words"). 
some other judges, ${ }^{314}$ Posner has mentioned nonconsensual physical touchings. Yet the cases are full of conflict over when such touchings constitute sexual harassment. In one case, for example, a court concluded that a man's seemingly sexual acts of placing his hands on a female coworker's hips, touching her breasts, and "playfully" choking her when she complained" 315 were "not as aggressive or coercive as that underlying a number of hostile sexual environment claims that have been unsuccessful in court." 316 To this court, the problem lay in the fact that the conduct was not sufficiently threatening. Yet, in another case, a man's plainly menacing actions of grabbing a woman's crotch and breast, forcing a penis into her hand, holding a knife to her throat, shoving her into a file cabinet, and threatening to "bang her head into the ground"317 were also found insufficient to ground a hostile work environment claim. ${ }^{318}$

In another case, Wimberly $v$. Shoney's, Inc., ${ }^{319}$ the fact of physical touching was deemed less important than whether such touching reflected sexual intent. The court found that a restaurant manager's acts in shaking a waitress by the shoulders and letting his arms and hands fall over her breasts were insignificant because they were "done without sexual designs upon her."320 Discerning when sexual designs underlay physical touchings, however, has proven to be a daunting task to which the courts have brought little consistency. To one court, the isolated act of slapping a woman on the rear end was a sexual act: "[A] slap on the buttocks in the office setting has yet to replace the hand shake." 321 To another, however, the act of "bagging," unexpectedly grabbing a male worker's genitals, was not a sexual activity. ${ }^{322}$ And to a third court, the act of stroking a woman's hair, even in the context of admiring her body and speculating about her sex life, was not a sexual gesture. ${ }^{323}$

314. See, e.g., Gillum v. Federal Home Loan Bank, 970 F. Supp. 843. 852 (D. Kan. 1997) ("None of [the defendant's] conduct was physically threatening and Gillum does not allege any unwelcome sexual advances. Nor does Gillum allege that [the defendant] engaged in any sexually suggestive touching or groping."); Harris v. Forklift Sys., Inc., 60 Empl. Prac. Dec. (CCH) 9 42,070, at 74,250 (M.D. Tenn. 1990) (finding that the sexual conduct "was not in the form of sexual propositions or physical touching" and was therefore insufficiently severe and pervasive to be actionable), off ${ }^{\circ} d .976$ F.2d 733 (6th Cir. 1992) (per curiam), rev'd on other grounds, 510 U.S. 17 (1993); Ross v. Double Diamond, Inc., 672 F. Supp. 261, 270 (N.D. Tex. 1987) ("Generally, unwelcome physical touching is more offensive than unwelcome verbal abuse.").

315. Domhecker v. Malibu Grand Prix Corp., 828 F.2d 307. 308 (Sth Cir. 1987).

316. Id. at 309.

317. Weinsheimer v. Rockwell Int'l Corp., 754 F. Supp. 1559, 1561 (M.D. Fla. 1990), aff'd. 949 F.2d 1162 (11th Cir. 1991).

318. See id. at 1567.

319. 39 Fair Empl. Prac. Cas. (BNA) 444 (S.D. Ga. 1985).

320. Id. at $448-49$.

321. Campbell v. Board of Regents, 770 F. Supp. 1479. 1486 (D. Kan. 1991).

322. See Quick v. Donaldson Co., 895 F. Supp. 1288, 1296 (S.D. lowa 1995) ("The only thing sexual about 'bagging' is that the aggressor aims his non-sexual aggression at genitals.").

323. See Downes v. FAA, 775 F.2d 288, 295 (Fed. Cir. 1985). 
If delineating when physical touchings are actionable has proven to be an uncertain endeavor, determining when other types of conduct amount to prohibited sexual advances has proven to be an equally ambiguous undertaking. One court, for example, was willing to characterize a supervisor's comment that his "penis stretches from here to District 1" advance," ${ }^{325}$ but held that the advance was too insignificant to constitute sexual harassment because it did not include any "offensive touching or threats." ${ }^{326}$ Other courts have been less willing to characterize similar sorts of verbal conduct as sexual advances. In one case, for instance, a recruiting official claimed that her boss subjected her to "outright sexual propositions," "a lewd practice of fondling his genitals in her presence," and the use of "vulgar language and innuendo"; $; 27$ he also "'gawked" at [her]" and crawled under a table where she was seated "in a public display of sexual behavior." ${ }^{328}$ The court, however, found that none of this behavior was sexually motivated. The boss had not leered at the plaintiff; instead, he had a "wander[ing]" eye. ${ }^{329}$ He had not fondled himself; he "had a bad habit of itching himself in the groin," which, "though perhaps unbecoming of a gentleman," was not "sexually offensive." ${ }^{\text {"30 }}$ His act of crawling under the table in an "effort to look up [the plaintiff's] dress" had nothing to do with sexuality, but instead had been done "as a playful event." 331 According to the court, "no incidents of physical or verbal conduct of a sexual nature ever occurred in any degree whatsoever." 332 In another case, the court found absurd the plaintiff's perception of her boss's conduct as a sexual advance. In the court's eyes, the older man's lavishing attention on his female subordinate, having dinner alone with her numerous times, assuming physical intimacies toward her (such as caressing her hands and placing his hands on her knee), and conferring gifts on her, were in no way sexually or romantically motivated. ${ }^{333}$ According to the court, the plaintiff was a naive woman, hypersensitive to men, who had fantasized her boss's attentions. ${ }^{334}$

Once the facts move beyond the realm of alleged sexual advances, courts have had even greater difficulty agreeing on whether the behavior amounts to forbidden conduct of a sexual nature. Verbal taunts and suggestive or crude comments.(sometimes accompanied by acts of physical hazing) have proven

324. Cohen v. Litt, 906 F. Supp. 957, 964 (S.D.N.Y. 1995).

325. Id. at 965 .

326. 1 .

327. Jackson-Colley v. Department of the Army Corps of Eng'rs, 655 F. Supp. 122, 126 (E.D. Mich. 1987).

328. Id. at 127.

329. Id.

330. Id.

331. Id. at 128.

332. Id.

333. See Sand v. Johnson Co., 33 Fair Empl. Prac. Cas. (BNA) 716, 725-26 (E.D. Mich. 1982).

334. See id. at 725 . 
to be particularly divisive in the courts. In one case, for example, a court held that a collection manager's calling a female employee "Syphilis," telling her she looked like a "streetwalker," and monitoring her bathroom breaks were not "harassment of a sexual nature," even when accompanied by crude speculations about the plaintiff's sex life at home. ${ }^{335}$ In another case, however, a court held that an assistant manager's inviting a car saleswoman to join his sexual exploits with his wife, flicking his tongue at the saleswoman in the showroom, and bragging about having looked up another saleswoman's dress constituted "sexual humiliation and degradation"-indeed, they amounted to "severe and pervasive sexual misconduct."

Courts also have embraced capricious and contradictory characterizations of derogatory epithets aimed at women workers. To one court, a police lieutenant's reference to a female police officer as "that broad" constituted the use of a "sexually-oriented epithet." ${ }^{337}$ To another court, however, a male coworker's "statement calling [a female auto worker] a 'sick bitch' was not overtly sexual in nature." 338 A third court had no difficulty concluding that a casino blackjack dealer's reference to a female floorperson as a "cunt" and "dumb fucking broad"339 were "sexually explicit and offensive terms." To this court, the dealer's use of such terms was "fundamentally different" from his calling men "asshole[s]" and "jerk[s]." $3+1$ Although the dealer may have denigrated both men and women, concluded the court, his abuse of women was distinctive because it "relied on sexual epithets, offensive, explicit reference to women's bodies and sexual conduct." 342 In the court's analysis, "It is one thing to call a woman 'worthless,' and another to call her a 'worthless broad.",343

Far from providing a bright-line test, the courts' focus on conduct that is sexual in nature has proven to be an indeterminate proxy for whether harassing conduct is based on sex within the meaning of Title VII. Instead, the focus on sexual conduct has opened up as many questions as it has answered, embroiling judges in tension-filled rulings that create a patchwork of justice.

335. Cline v. General Elec. Credit Auto Lease, 54 Fair Empl. Prac. Cas. (BNA) 419, 423 (N.D. III. 1990); cf. Hall v. Gus Constr. Co., 842 F.2d 1010, 1013-14 (8th Cir. 1988) (discussing. but not clearly rejecting, a company's argument that a male coworker's use of the name "Herpes" to refer to the plaintiff was nonsexual in nature).

336. Sassaman v. Heart City Toyota, 879 F. Supp. 901.910 (N.D. Ind. 1994).

337. Woemer v. Brzeczek, 519 F. Supp. 517,520 (N.D. 111. 1981).

338. Galloway v. General Motors Serv. Parts Operations, No. 92-C-5987, 1994 U.S. Dist. LEXIS 16902, at *8-9 (N.D. Ill. Nov. 23, 1994), aff'd, 78 F.3d 1164 (7th Cir. 1996). Interestingly, in thus case. the court noted that it was "using the term 'sexual" to denote both alleged actions that were intended to indicate sexual desire as well as actions that were intended to degrade plaintiff because of her sex." Id. at *9 n.5.

339. Steiner v. Showboat Operating Co., 2S F.3d 1459, 1461 (9th Cir. 1994).

340. Id. at 1463 .

341. Id. at 1464 .

342. Id. at 1463 .

343. Id. at 1464. 
Although judges may long for a clear standard, it seems unlikely that most are unaware of the lack of precision offered by the current paradigm. Thus, there must be another reason why courts have focused on sexual conduct as the foundation for hostile work environment harassment.

\section{The Courts' Failure To Understand the Role of Work in Producing Gender Inequality}

There is a deeper explanation for the courts' emphasis on sexual conduct as the core of sex-based harassment. Highlighting sexual abuse has allowed judges to feel enlightened about protecting women from sexual violation while relieving them of the responsibility to redress broader gender-based forms of disadvantage at work. Even though a sexuality-based standard has not yielded predictable results, singling out sexual abuse may permit judges the illusion that they are addressing a problem that can be isolated from other workplace conditions. Indeed, the disaggregation of sexual harassment from other forms of sex discrimination presumes precisely such a separation. To confront the fact that sexual misconduct may be only one-indeed, perhaps only a relatively minor-manifestation of a larger pattern of nonsexual harassment and discrimination raises the disquieting prospect that the world of work is systematically gender-biased. Judges may understandably wish to avoid confronting such a problem.

The larger political and cultural environment has placed little pressure on judges to do so. The courts' focus on protecting women from sexual abuse was inspired by a cultural-radical feminist tradition that characterized heterosexual sexual relations as a central force creating gender inequality. ${ }^{344}$ That feminist tradition may have resonated with more conservative political tendencies to create a climate that enabled judges to perceive that women, more than men, are routinely subjected to sexual advances and assaults that may endanger and harm them.

Courts have not understood, however, that the gender stratification of work-who does what type of work, under what conditions, and for what reward-is at least as influential as sexual relations in producing women's disadvantage. Although judges understand that women are victimized as sexual objects, they have not been able to see that women are also systematically harassed, discriminated against, and marginalized as workers in ways that render them unequal on the job and, as a result, in many other realms of life. The assumptions underlying the two-tier structure of causation may seem natural, but they are the product of larger political currents. To most judges, sexual advances seem intuitively gender-based because cultural-radical feminists, and the sexual desire-dominance paradigm they inspired, have

344. See supra Subsection I.B.1. 
articulated how women are harmed through sexual relations. Yet, in part because no political tradition has expressed with the same force the ways in which women are rendered unequal through workplace relations, judges have difficulty perceiving the characteristic problems that confront working women as gender-based.

In case after case in which nonsexual harassment predominates, in both hostile work environment claims and the disparate treatment claims from which they are disaggregated, the courts have rendered decisions on causation that reveal a fundamental lack of understanding of the gender-based quality of harassing and harmful actions directed at women in the workplace. In the most egregious group of cases, courts seem to be engaged in outright denial: They refuse to characterize conduct as sex-based even when it is accompanied by expressions of resentment or unease directed at women workers who try to make it in traditionally male occupations or jobs.

Recall that in Ramsey v. City of Denver, ${ }^{345}$ the court failed to designate as sex-based the mistreatment of a female engineer, even though her boss had stated openly that he believed the plaintiff's job was unsuitable for women. According to the court, the engineer had brought her troubles upon herself through her lack of "interpersonal skills," including being "overbearing" and "over-demanding."346 Or recall Reynolds v. Atlantic City Convention Center ${ }^{347}$ in which the court rejected a claim that a female electrical subforeman's dismissal and other mistreatment were sex-based, even though the record included a number of gender-based comments-including an earlier remark by the union business agent that there would never be an appropriate time to have a woman in her position. ${ }^{348}$ Or consider a third case, in which a female construction technician alleged that her supervisor had discriminatorily denied her the opportunity to obtain experience in a construction position; she claimed that the inability to do so had hindered her from advancing or earning overtime. ${ }^{349}$ The court found that the plaintiff had failed to make a prima facie case of sex discrimination, even though her supervisor had denied her a sought-after temporary assignment shortly after exclaiming, "Fucking women, I hate having fucking women in the office!"3so According to the court, the supervisor's statement did not evince discriminatory intent. It showed only that he "unprofessionally offered his private negative view of women during a display of bad temper at work." 351

345. 907 F.2d 1004 (10th Cir. 1990), discussed supro text accompanying notes 259-268.

346. Id. at 1010 .

347. 53 Fair Empl. Prac. Cas. (BNA) 1852 (D.N.J. 1990), aff'd. 925 F.2d 419 (3d Cir. 1991), discussed supra text accompanying notes 183-196.

348. See id at 1863.

349. See Heim v. Utah, 8 F.3d 1541 (10th Cir. 1993).

350. Id. at 1546 .

351. Id. at 1547. 
In other cases, courts have found that women workers' mistreatment was prompted by their own shortcomings rather than by their sex-even as judges disregard signs that the evaluation of the plaintiffs' competence may not have been free from gender stereotyping. In a case with facts eerily reminiscent of Price Waterhouse v. Hopkins, ${ }^{352}$ for example, a female executive director who had dramatically increased the receipts of a nonprofit organization was replaced by a man. ${ }^{353}$ Her troubles began when she fired a male staff member liked by members of the Board of Directors; the troubles were exacerbated when she filed a sexual harassment charge against a Board member, who then placed her on probation. Even though Board members had told her that the best kind of woman is a "Honey-Do" and "suggested that she take a Dale Carnegie course" to learn how to deal with the Board, ${ }^{354}$ and even though one member of the Board had ripped a feminist poster off her wall and told her "it's thinking like this that got you fired,"35s the court rejected the plaintiff's claims that the Board had mistreated and eventually fired her because of her sex. Instead, the court accepted the Board's explanation that the director was too "abrasive" to do her job well, without inquiring into whether gender stereotyping had affected the Board's perception. ${ }^{356}$ As the Supreme Court has recognized, however, strong women managers are often perceived to be unduly abrasive. ${ }^{357}$

Indeed, in numerous cases in which women work in male-dominated settings, courts have overlooked evidence that the denigration of women's competence, authority, or entitlement to the job is itself a core component of what makes the work environment sexist and hostile. Recall Gross v. Burggraf Construction Co. ${ }^{358}$ in which the court failed to characterize as gender-based discrimination a female construction worker's deprecation at the hands of an authoritarian supervisor who conceded that he had hired the plaintiff only to comply with perceived affirmative action requirements and who had a record of driving women away from the job. In another case, a female firefighter alleged that she was subjected to many forms of differential treatment, much of which was designed to undermine her competence. ${ }^{359}$ Her superiors made remarks about her lack of professional ability, denied her the opportunity to attend training seminars, disciplined her for accompanying the deputy fire chief

352. 490 U.S. 228 (1989), discussed supra text accompanying notes 287-289.

353. See Petrosky v. Washington-Greene County Branch Pa. Ass'n for the Blind, 663 F. Supp. 821 (W.D. Pa. 1987), aff'd, 845 F.2d 1014 (3d Cir. 1988).

354. Id. at 822 .

355. Id. at 824 .

356. Id. at 825 .

357. See Price Waterhouse, 490 U.S. at 255-56. By taking on the role of the competent executive, they assume a prerogative traditionally reserved for men and trigger gender-based anxieties. See KANTER, supra note 130, at 201-05; Martha Chamallas, Listening to Dr. Fiske: The Easy Case of Price Waterhouse v. Hopkins, 15 VT. L. REV. 89, 105-06 (1990).

358. 53 F.3d 1531 (10th Cir. 1995), discussed supra notes 271-285 and accompanying text.

359. See Halasi-Schmick v. City of Shawnee, 759 F. Supp. 747 (D. Kan. 1991). 
on an investigation, and even required her to do secretarial work when the secretary was out. In addition, her fire chief called her a "dumb blonde," and her supervisor accused her of having an affair with a coworker. ${ }^{360}$ Despite the plaintiff's allegation that this conduct "affected her attitude toward work and made her feel that she wasn't respected and wasn't going to get anywhere while these people were her superiors," ${ }^{361}$ as well as her offer to prove that nine other women had experienced the same types of harassment, the court dismissed her hostile work environment claim on summary judgment for insufficient proof that the harassment occurred because of her sex. ${ }^{362}$

As part of this overall pattern, courts have also failed to comprehend the opportunity for discrimination in the provision of training. Denying women the training or learning opportunities they need to master the work is a problem that is particularly prevalent in male-dominated settings, where much of the learning is acquired informally on the job. Women's complaints about inadequate training are legion, in both the literature and the case law. ${ }^{363}$ For example, recall Scott v. Sears, Roebuck \& Co., ${ }^{364}$ in which an auto mechanic trainee at Sears alleged that she was denied the opportunity to perform brake jobs and, as a result, never learned how to do them as quickly as the more senior male mechanics. The court ignored this aspect of her claim, concluding that she was fired because of her lack of productivity at brake work, without examining whether the training process was itself discriminatory. ${ }^{365}$ In another case, the first female firefighter in Wichita, Kansas received demeaning remarks from her fellow recruits. ${ }^{366}$ One man predicted that the plaintiff would last only a month; several said that she was not strong enough to do the job; another refused to take orders from a "damn bitch"; and another said that she should join the men in the shower since she was "doing a man's job." ${ }^{367}$ As part of the general pattern of discrimination, the plaintiff claimed that she was given inadequate hands-on experience on fire engines and their equipment, and that when she was transferred to a dispatcher position, she was "rushed through the training and put on the ... dispatch board before she felt ... ready for that responsibility." 368 After severing plaintiff's training claims from the recruits' derogatory remarks and holding that the remarks alone did

360. Id. at 751-52.

361. Id.

362. See id. at 752 .

363. For examples of women's complaints about inadequate traning. see WALSHOK. supra note I, at 188 , which reports that the most common complaint of women in male-dominated jobs is inadequate training; and Brigid O'Farrell \& Sharon L. Harlan. Crafnworkers and Clerks: The Effecs of Male Co-Worker Hostility on Women's Satisfaction with Non-Traditional Jobs. 29 SOC. PROBS. 252. 259 (1982). which reports that women in male-dominated jobs are excluded from critical on-the-job tranning.

364. 798 F.2d 210 (7th Cir. 1986), discussed supra notes 197-209 and accompanying text.

365. See id. at 214.

366. See Downum v. City of Wichita, 49 Fair Empl. Prac. Cas. (BNA) 162 (D. Kan. 1986).

367. Id. at 166.

368. Id. at 165 . 
not create a hostile work environment, the court concluded that the plaintiff had not shown that any training deficiencies were based on her sex. According to the court, the "[p]laintiff's subjective feelings of being rushed through her training and of not being ready to handle the position in which she was placed do not constitute even circumstantial evidence of . . discriminatory gender-based acts." 369

Courts have also neglected the potential gender dynamics underlying acts of work sabotage, including physical attacks. In one case, for example, a woman who moved up from a job as a brusher to become a laboratory trainee alleged that her new male colleagues greeted her with efforts to destroy her work. ${ }^{370}$ One male coworker left a note telling her there were no problems with her equipment; upon inspection, however, she found two serious problems that, if left unattended, would have shut down the mill and caused her to be fired. According to the plaintiff, this man "always complained and tried to make her do her work poorly." "371 Another "embarrassed [her] every work day ... by not talking very good about females." 372 After ruling that these incidents were insufficiently sexual to be actionable, the court concluded that the plaintiff failed to show that she was fired because of her sex. Not only did the facts fail to reflect "discriminatory animus," said the court, but it was "impossible to conclude that plaintiff was "harassed' at all." 373 In the court's eyes, the alleged acts of work sabotage showed only that the plaintiff "was a more careful employee than [her coworker], not that [he] was purposefully harassing her." 374

In addition, recall Weinsheimer v. Rockwell International Corp., ${ }^{375}$ in which the court rejected a female thermal protection inspector's challenge to her coworker's crude sexual demands and physical violence. The court concluded that the man's behavior was not traceable to the plaintiff's sex, but "to general causes that were not sexually motivated," including the plaintiff's "confrontational and abusive personality." According to the court, the plaintiff and her assailant "engaged in frequent and heated fights," and "these altercations usually grew out of work or personal issues, rather than having a sexual animus."377 As an example of a fight that was "based not upon sex, but rather upon work or personal disputes," 378 however, the court cited an incident in which the plaintiff's coworker shoved her into a file cabinet after

369. Id.

370. See Hosemann v. Technical Materials, Inc., 554 F. Supp. 659 (D.R.I. 1982).

371. Id. at 663 .

372. Id. at 663 n.II.

373. Id. at 666 .

374. Id.

375. 754 F. Supp. 1559 (M.D. Fla. 1990), aff'd, 949 F.2d 1162 (11th Cir. 1991), discussed supra text accompanying notes $236-237,317-318$.

376. Id. at 1565 .

377. Id.

378. Id. at 1565 n. 15 . 
she reprimanded him for handling tiles with his bare hands. Even though the court conceded that the reprimand "was a proper exercise of her duties as an inspector, ${ }^{, 379}$ it did not occur to the judge that the coworker's animosity may have stemmed from his difficulty in submitting to the authority of a woman. Instead, the court concluded that the plaintiff's problems with this man and the other technicians stemmed from the fact that she was argumentative and slothful on the job.

In a similar vein, courts sometimes fail to see that the withholding of perks and privileges needed to succeed on the job can be part of a gender-based campaign to discredit women workers' competence. In Rabidue v. Osceola Refining Co., ${ }^{380}$ for example, Vivien Rabidue, the sole female manager in an oil refinery, was excluded from activities she needed to perform her duties and progress in her career:

[U]nlike male salaried employees, she did not receive free lunches, free gasoline, a telephone credit card or entertainment privileges. Nor was she invited to the weekly golf matches. ... After plaintiff became credit manager defendant prevented plaintiff from visiting or taking customers to lunch as all previous male credit managers had done. ... Plaintiff's . . . supervisor . . . stated to another female worker . . . that "Vivienne . . . is doing a good job as credit manager, but we really need a man on that job," adding "She can't take customers out to lunch." Aside from this Catch-22, [the supervisor] also remarked plaintiff was not forceful enough to collect slow-paying jobs. ${ }^{381}$

As this case shows, the denial of perks and privileges can be difficult to distinguish from other conduct designed to undermine a woman's authority and undercut her performance on the job. Indeed, as the dissenting judge observed,

[P]laintiff was [also] frequently told to tone down and discouraged from executing procedures she felt were needed to correct waste and improve efficiency as her job required. Not only did plaintiff receive minimal support, but she was repeatedly undermined. For example, [one male supervisor] once directed his employees to ignore plaintiff's procedures for logging time and invoices, a particularly damaging directive given plaintiff's responsibility of coordinating the work of [that supervisor's] staff. In another example, plaintiff returned from her vacation to find that none of the check depositing procedures agreed upon had been implemented and that some of her duties had been permanently transferred to the male who filled in during her vacation. ${ }^{382}$

379. Id

380. 805 F.2d 611 (6th Cir. 1986).

381. Id. at 624 (Keith, J., concurring in part and dissenting in part).

382. Id at 624-25. 
In spite of the blatant nature of these actions, and in spite of the fact that Rabidue was also subjected to denigrating obscenities and surrounded by pornographic displays, the Sixth Circuit affirmed the district court's rulings against the plaintiff. After disaggregating the sexual and nonsexual behavior, the court of appeals upheld the finding that the plaintiff was not subjected to a hostile work environment or disparate treatment. ${ }^{383}$ According to the court, Rabidue was not fired because of her sex, but because of her "irascible and opinionated personality and her inability to work harmoniously with co-workers and customers." 384

Courts also frequently fail to comprehend that forcing women to perform stereotypically female tasks that are not part of their regular job duties signals a derogation of their work competence that is rooted in gendered expectations of what types of work are suitable for women to perform. In one case, a civil service secretary who took a pay cut to move into a technical engineering aide position specifically sought assurance, before transferring, that she would not be required to perform secretarial duties in the new job. ${ }^{385}$ Notwithstanding assurances to the contrary, the executive director of the agency demanded that she substitute for his secretary, twice a day, on a permanent basis. Even though the director had ordered only two people-the plaintiff and another woman who possessed no secretarial skills whatsoever-to relieve his secretary, and had never asked a male worker to do so, the court failed to perceive the assignment (and the plaintiff's subsequent firing for failing to carry it out) as sex-based. ${ }^{386}$

The facts of these cases are not unique. They are representative of the types of harassment and discrimination experienced by many women at work. Every day, in workplaces all over the country, women are pressured to conform to their employers' and coworkers' images of who and what type of workers "women" are supposed to be. Yet, as the results and reasoning of such cases show, the courts have not understood the magnitude of gender discrimination and marginalization experienced by women in the work world. Nor have they understood the extent to which hostile workplace relations contribute to shaping jobs and people along gendered lines. As these cases suggest, and as I explain more fully below, characterizing women as incompetent at certain types of work is a central component of the harassment

383. See id. at 618,622 .

384. Id. at 615 .

385. See Smith v. Texas Dep't of Water Resources, 818 F.2d 363 (5th Cir. 1987).

386. See id. at 364-67; see also Cobbins v. School Bd., No. 90-1754, 1991 WL 1828, at *3 (4th Cir. Jan. 14, 1991) (rejecting a female teacher's allegation that her male principal's request that she perform secretarial-type tasks helped create a sex-based hostile work environment); Halasi-Schmick v. City of Shawnee, 759 F. Supp. 747, 751 (D. Kan. 1991) (rejecting a claim by a female firefighter who was made to relieve a secretary when the secretary was out); see also Rabidue, 805 F.2d at 624 (rejecting a claim by a female salaried manager in an oil refinery who was seated with female clerical employees at meetings while male salaried employees were permitted to stand at the front of the room). 
that contributes to stratifying work along gender-based lines. We need a new account of hostile work environment harassment that places such gender-based, competence-undermining conduct at its center, one that does not reduce all harassment to sexual objectification or desire.

\section{AN Alternative ACCOUNT OF HOSTILE WORK ENVIRONMENT HARASSMENT: A COMPETENCE-CENTERED PARADIGM}

To begin constructing a more accurate account of hostile work environment harassment means recognizing the importance of the realm of paid work in creating women's second-class status. Contrary to the assumption of the cultural-radical feminist tradition that inspired the development of harassment law, men's desire to exploit or dominate women sexually may not be the exclusive, or even the primary, motivation for harassing women at work. Instead, a drive to maintain the most highly rewarded forms of work as domains of masculine competence underlies many, if not most, forms of sex-based harassment on the job. Harassment has the form and function of denigrating women's competence for the purpose of keeping them away from male-dominated jobs or incorporating them as inferior, less capable workers.

This part develops an alternative account of hostile work environment harassment that is rooted in these realities. I refer to the new account as a "competence-centered" paradigm, for it understands harassment as a means to reclaim favored lines of work and work competence as masculine-identified turf-in the face of a threat posed by the presence of women (or lesser men) who seek to claim these prerogatives as their own. ${ }^{387}$ This account provides a more comprehensive understanding of the customary cases of male-female harassment by supervisors and coworkers and also allows us to understand some less conventional forms of harassment, such as harassment of female supervisors by their male subordinates.

387. This competence-centered account is meant to evoke the image of domunant male workers defending their occupational terrain-while women (and other men) seck to lay claim to it-in the way that people historically have struggled over real property. This description suggests that. consciously or unconsciously, many male workers may view not only their jobs, but also the male-domınated composition and masculine identification of their work, as forms of property to which they are entutled. I am indebied to Carol Rose for helping me see this point. See Carol M. Rose, Women and Properry: Ganning and Losing Ground, 78 VA. L. REV. 421,436 \& n.42 (1992). Cf. DAVID ROEDIGER. THE WAGES OF WHITENESS: RACE AND THE MAKING OF THE AMERICAN WORKING CLASS 13 (1991) (arguing that "the pleasures of whiteness could function as a "wage' for white workers," as 19 th-century white workers came to "define and aceept their class positions by fashioning identities as 'not slaves' and 'not blacks"'): Cheryl Harns, Whuteness as Property, 106 HaRv. L. Rev. 1707 passim (1993).

The competence-centered approach is not intended to portray all men as "naturally" possessing a unified gender interest in protecting the male-dominated composition or image of their jobs. Men do not automatically perceive themselves as having a unified gender interest, nor do they have a monolithic view about the meaning of manhood. Indeed, as the account emphasizes, harassment is a medium through which some men seek to defend their view of masculine interests and identity against contesting visions proposed by other men. 


\section{A. The Link Between Job Segregation and Hostile Work Environments}

Both scholarly research and everyday experience reveal that the world of work plays a pivotal role in producing gender inequality between men and women. This is not surprising. In advanced industrial societies, wage work is a primary source of material security and psychological well-being: A job provides both the means to meet life's concrete needs and a position that confers a sense of place in the world. ${ }^{388}$ As scholars have begun to recognize, work not only bestows a livelihood and sense of community, but also provides the basis for full citizenship, ${ }^{389}$ and even for personal identity. Like it or not, we are what we do. ${ }^{390}$

If the job makes the person, experience in the job world molds people along gendered lines. ${ }^{391}$ As numerous researchers have documented, one of the most striking features of the world of work is the extent to which it is stratified by sex. ${ }^{32}$ Almost universally, men and women work at different jobs. ${ }^{393}$ At each level of the occupational and educational ladder, the jobs

388. For an eloquent statement of this position, see KANTER, supra note 130, at 3. Kanter writes: The most distinguished advocate and the most distinguished critic of modern capitalism were in agreement on one essential point: the job makes the person. Adam Smith and Karl Marx both recognized the extent to which people's attitudes and behaviors take shape out of the experiences they have in their work.

Id; see also STUDS TERKEl, WORKING at xiii (Ballantine 1985) (1972) ("[Work] is about a search, too, for daily meaning as well as daily bread, for recognition as well as cash, for astonishment rather than torpor; in short, for a sort of life rather than a Monday through Friday sort of dying."); WILLIAM JULIUS WILSON, WHEN WORK DISAPPEARS: THE WORLD OF THE NEW URBAN POOR 73 (1996) ("[W] simply a way to make a living and support one's family. It also constitutes a framework for daily behavior and patterns of interaction. . . . In the absence of regular employment, life, including family life, becomes less coherent.").

389. See ERIC Foner, Free SOIL, Free Labor, Free MEN: The IdeOlogy of the Republican PARTY BEFORE THE CIVIL WAR 8-10, 11-18 (1995); Carol Pateman, The Patriarchal Welfare State, in DEMOCRACY AND THE WELFARE STATE 231, 238-40 (Amy Gutmann ed., 1988).

390. Cf. 1 HERBERT HILL, BLACK LABOR AND THE AMERICAN LEGAL SYSTEM 34 (1977) (describing work as "the most significant source of identity for western men and women"); REPORT OF THE NATIONAL ADVISORY COMMISSION ON CIVIL DISORDERS 252 (N.Y. Times ed., 1968) ("'The principal measure of progress toward equality [is] that of employment. It is the primary source of individual or group identity. In America, what you do is what you are: to do nothing is to be nothing; to do little is to be little." (quoting Daniel Patrick Moynihan)).

391. See KANTER, supra note 130, passim; Schultz, supra note 210, passim.

392. Numerous sources document the extent of occupational and job segregation by sex. See, e.g., JERRY A. JACOBS, REVOLVING DOORS: SEX SEGREGATION AND WOMEN'S CAREERS 23 (1989) (showing that, throughout the $1980 \mathrm{~s}$, just under $60 \%$ of female workers would have been required to switch to predominantly male occupations to achieve sex-integrated occupations); Jerry A. Jacobs, Long-Term Trends in Occupational Segregation by Sex, 95 AM. J. SOC. 160, 160 (1989) (showing that, as recently as 1985, over two-thirds of working women were employed in occupations in which at least $70 \%$ of the workers were female).

393. Measuring sex segregation with data on occupations understates the degree of segregation because, even within apparently integrated occupations, men and women tend to work at different jobs. Indeed, one famous study of segregation at the firm level found that men and women almost always work in jobs that are completely segregated. See William T. Bielby \& James N. Baron, $A$ Woman's Place Is with Other Women: Sex Segregation Within Organizations, in SEX SEGREgation IN THE WORKPLACE: TRENDS, EXPLANATIONS, REMEDIES 27, 35 (Barbara F. Reskin ed., 1984) (finding that, in a random sample of 393 California firms, fully $90 \%$ of workers were in job titles held by workers of only one sex). Sex segregation is an entrenched feature of workforces around the world. See Jerry A. Jacobs \& Suet T. Lim, Trends in 
women do tend to pay less and to offer lower status and less opportunity for advancement than those that men do. ${ }^{394}$ Especially at the lower ends of the economic spectrum, women work at jobs that offer fewer prospects for challenge, creativity, and physical mobility. Jobs traditionally occupied by women are more likely to be governed by petty, paternalistic forms of authority. ${ }^{395}$ Women's inferior position in the world of work confers disadvantages that burden women throughout other realms of life.

The linkages between work and gender are deep-so deep that we tend to think of most types of work as essentially "masculine" or "feminine." $3 \%$ These linkages may run especially deep for men. At least since the onset of industrialization, paid work has provided a main source of authority and identity for men. Not only have they struggled to earn a wage that would allow them to head families, ${ }^{397}$ but they have also sought to defend their work from deskilling and the encroachment of women (and less powerful men) by defining their work competence in idealized masculine terms. Work competence has been contested terrain, one on which male jobholders have formed and fought for their interests-both as workers and as men-against perceived threats from women and less privileged men (and often too against threats from their employers, whom they have viewed as trying to use these other groups to undercut them). ${ }^{398}$

Occupational and Industrial Sex Segregation in 56 Countries, 1960-1980. in GENDER INEQUALTTY AT WORK 259 (Jerry A. Jacobs ed., 1995).

394. The most significant factor contributing to the male-female wage gap, at least among workers without college degrees, is women's concentration in lower-paying. female-dominated occupations and jobs. See, e.g., BUREAU OF THE CENSUS, U.S. DEP'T OF COMMERCE, CURREAT POPULATION REPORTS, Household ECONOMIC Studies. Series P-70, No. 10. Male-Female Differences iN Work EXPERIENCE, OCCUPATION, AND EARNINGS: 1984, at 9-10 (1987) (finding that approximately 30\% of the male-female earnings differential among those without college degrees is accounted for by the percentage of persons in an occupation who are female and that there is "a strong negative relationship between wage rates and the relative number of females in the occupation"): WOMEN, WORK AND WAGES: EQUAL PAY FOR JOBS OF EQUal, VALUE 35 (Donald J. Treiman \& Heidi I. Hartmann eds., 1981) (finding that, depending on the method of computation, between $35 \%$ and $39 \%$ of the male-female wage gap in the workforce as a whole is attributable to occupational segregation when detailed occupational classifications are used). Entry-level female jobs tend to be on shor mobility ladders that offer litte or no opponunity for advancement, see BERGMANN, supra note 52, at 106-11, and female jobs tend to have less prestige than male jobs. Even when women work in male-dominated jobs, segregation creates a context in which they are perceived to have less prestige than their male counterparts. See Brian Powell \& Jerry A. Jacobs, Gender Differences in the Evaluation of Prestige, 25 SOC. Q. 173 (1984). For a discussion of these and other negative consequences of sex segregation for women workers, see WONEN'S WORK. MEN'S WORK: SEX SEGREGATION ON THE JOB 9-17 (Barbara F. Reskin \& Heidi I. Harmann eds., 1986).

395. See RUTH CAVENDISH, WOMEN ON THE LINE $81-97$ (1982); STANSEl, supra note 226, al 122. 23; see also Wendy C. Wolf \& Neil D. Fligstein. Sex and Authorin in the Wortplace. 44 A.M. SOC. REv. 235, 250 (1979) ("Men are more likely to hire and fire, determine pay and supervise than women. ... [M]en get more authority for similar levels of occupational status and sex labeling of job held than wornen. at least in the access to higher levels of supervision.").

396. See Schultz, supra note 210 , at 1800-05.

397. See alice Kessler-Harris, a Woman's Wage: Histories, meanings and Social CONSEQUENCES 19-20, 67-7I (1990); Martha May. The Historical Problem of the Fomily Wage: The Ford Motor Company and the Five Dollar Day, 8 FEMINIST STUD. 399. 401 (1982).

398. For an illuminating analysis of the centrality of work competence to masculine identity among printers in the 19th century, see Ava Baron, An "Other" Side of Gender Antagonism at Work: Mlen. Boys. 
Today, as in times past, men can retain some measure of economic superiority over women by holding on to the most prestigious, highly paid jobs. Economic superiority, in turn, ensures men's head-of-household status, which confers the ability to attract women who will clothe, feed, house, and nurture them and their children. Economic power also breeds greater political power, which assures men's continued edge in controlling most public institutions. Mastery over the most challenging work ensures the means to create the dominant forms of knowledge and culture. In addition, economic superiority and monopolization of the most challenging work assures men a sense of identity as men. Breadwinning, mastery, and mobility are central to mainstream masculinity. ${ }^{399}$ Without them, it is difficult to see what "separate[s] . . the 'men' from the 'girls." 400

It is not surprising, therefore, that numerous studies have shown that men tend to define their manhood in terms of their status as breadwinners and as masters of uniquely masculine skills. ${ }^{401}$ Nor is it surprising that incumbent male workers have sought to defend their occupational turf from incursion by women by branding them as incompetent. ${ }^{402}$ The long history of entrenched sex segregation of work has encouraged male workers to adopt proprietary attitudes toward their jobs. The major purpose of Title VII was to dismantle sex segregation by integrating women into work formerly reserved for men. ${ }^{403}$ Yet, desegregating the workforce has proved to be a daunting task,

and the Remasculinization of Printers' Work, 1830-1920, in WORK ENGENDERED: TOWARD A NEW HISTORY OF AMERICAN LABOR 47 (Ava Baron ed,, 1991). See also Mary H. Blewett, Manhood and the Market: The Politics of Gender and Class Among the Textile Workers of Fall River, Massachusetts, 1870. 1880, in WORK ENGENDERED: TOWARD A NEW HISTORY OF AMERICAN LABOR, supra, at 92, 100 (showing how immigrant male spinners defended their manly competence by portraying spinning as exhausting work, "not a fitting employment for females," in the face of mill agents' attempts to "denigrate spinning as a manly trade by insisting that 'girls run mules easily and successfully' in other Massachusetts mills").

399. For historical examples of the importance of work to masculine identity, see ARTHUR BRITTAN, MASCULINITY AND POWER (1989); Baron, supra note 398; and Michael Grossberg, Institutionalizing Masculinity: The Law as a Masculine Profession, in MEANINGS FOR MANHOOD: CONSTRUCTIONS OF MASCULINITY IN VICTORIAN AMERICA 133 (Mark C. Cames \& Clyde Griffen eds., 1990).

400. Michelle M. Benecke \& Kristin S. Dodge, Military Women in Nontraditional Fields: Casualities of the Armed Forces' War on Homosexuals, 13 HARV. WOMEN's L.J. 215, 236 n.144 (1990) (quoting Mary Ann Tetreauit, Gender Belief Systems and the Integration of Women in the U.S. Military, MINErva, Spring 1988 , at 61,61-62).

401. See, for example, the studies cited in BRITTAN, supra note 399; and SUSAN FALUDI, BACKLASH: THE UNDECLAREd WAR AGAINST AMERICAN WOMEN 65 (1991).

402. Heidi Hartmann's early article on occupational segregation by sex reveals that in both England and the United States in the 1800 s and early 1900s, the efforts of male workers and their unions to exclude women from male-dominated occupations frequently involved efforts to deprive the women of necessary training or skills. See Hartmann, supra note 49, at 155-65. As Hartmann notes, even the unions' demands for equal pay for equal work for women-a centerpiece of modem feminist reform-was "a way to protect the men's wage scale, not to encourage women." Id. at 164. The unions had helped to prevent women from obtaining the requisite skills, and "[w]omen who had fewer skills could not demand, and expect to receive. equal wages." Id.

403. Those who spoke in favor of the amendment adding the prohibition against sex discrimination to the original 1964 Civil Rights Act focused primarily on the injustice of sex segregation of work. See, e.g., 110 CONG. REC. 2579-80, 2580-81 (1964) (statement of Rep. Griffith); id. at 2580-81 (statement of Rep. St. George). Moreover, when Congress amended Title VII in 1972, see Equal Employment Opportunity Act of 1972, Pub. L. No. 92-261, 86 Stat. 103 (codified as amended at 42 U.S.C. $\S 2000 \mathrm{e}(\mathrm{j}$ ) 
for men can create hostile and sexist work environments as a way to retain the better types of work for themselves. Indeed, research shows that women who work in male-dominated settings are more likely than other women to experience hostility and harassment at work. ${ }^{404}$ Not all the men in a work setting-nor even the majority-need to participate in the harassment. It takes only a few, particularly if they are able to secure the acquiescence of supervisors, to make the job environment hostile and alienating to any woman who dares to upset the "natural" order of segregation.

Research also confirms what the earlier analyses of the hostile work environment harassment cases suggest: For many, if not most, women workers, neither sexual desire nor sexual advances are the core of the problem. ${ }^{\text {+os }}$ Where sexual misconduct occurs, it is typically part of a broader pattern of harassment designed to reinforce gender difference and to claim work competence and authority as masculine preserves. Whatever men's motivations or sources of insecurity, harassment is a central process through which the image of (certain) work as masculine is sustained. If there are no women in the job, then the work's content can be described exclusively in terms of the manly personal characteristics of those who do it. If, on the other hand, women are actually succeeding at the work, it becomes far more difficult to define the job with reference to stereotypically masculine images. As one female pipefitter explained:

Some of the men would take the tools out of my hands. You see it is just very hard for them to work with me because they're really into

(1994)), both the House and the Senate made clear that they considered such sex segregation to be the primary evil for the statute to address. See H.R. REP. No. 92-238, at 4-5 (1971) ("“lW Jomen are placed in the less challenging, the less responsible and the less remunerative positions on the basis of their sex alone. Such blatantly disparate treatment is particularly objectionable in view of the fact that Title VII has specifically prohibited sex discrimination since its enactment in 1964."), reprunted in 1972 U.S.C.C.A.N. 2137, 2140; S. REP. NO. 92-415, 1st Sess., at 7 (1971) (including simular statements).

404. See, e.g., SEXUAL HARASSMENT IN THE FEDERAL. WORXPLACE, supra note 13, al 51.52 (reporing an increased likelihood of harassment for women in male-dominated jobs); SEXUAL. HARASSMENT IN THE FEDERAL GOVERNMENT, supra note 13, at 20 (reporting similar results from a 1987 survey): Barbara A. Gutek \& Bruce Morash, Sex Ratios, Sex-Role Spillover, and Sexual Harassment of Women at Work. J. Soc. ISSUES, Winter 1982, at 67, 67-68 (reporting that women in male-dominated work environments were more likely to report harassment and accompanying negative consequences than women in other work setungs): Susan Martin, Sexual Harassment: The Link Joining Gender Stratification. Serualun: and Women's Economic Status, in WOMEN: A FEMINIST PERSPECTIVE 57,61 (J. Freeman ed., th ed. 1989) (citing studies showing that the greater the proportion of men in a work group. the more likely women are to be harased).

405. See, e.g., Louise F. Fitzgerald et al., The Incidence and Dimensions of Sexual Harassment in Academia and the Workplace, $32 \mathrm{~J}$. VOCATIONAL BEHAV. 152.160 tbl.1, 166 tbl.2 (1988) (revealing that. in a large sample of university students and employees, women in both groups were much more likely to experience forms of nonsexual gender harassment-including being "treated differently due to gender" or being subjected to "sexist remarks about career options"- han sexual forms of harassment); see also MARTIN, supra note 209, at 10 ("[W] also face another pervasive and sinister kind of harassment which is gender-based, but may have nothing to do with sex. It is harassment aimed at us simply beeause we are women in a 'man's' job, and its function is to discourage us from staying in our (rades."); $c$. Schultz. supra note 210 , at $1832-33$ (discussing the importance of recognizing nonsexual forms of hostility against women workers). 
proving their masculinity and being tough. And when a woman comes on a job that can work, get something done as fast and efficiently, as well, as they can, it really affects them. Somehow if a woman can do it, it ain't that masculine, not that tough. ${ }^{406}$

By driving women out of nontraditional jobs, harassment reinforces the idea that women are inferior workers who cannot meet the demands of $a$ "man's job." More subtly, for women who stay in nontraditional jobs, harassment exaggerates gender differences to remind them that they are "out of place" in a "man's world." By simultaneously labeling the women "freaks" or "deviants" and pressuring them to conform to the dominant culture, men preserve the image of their jobs as masculine work that no real woman would do. By marking nontraditionally employed women workers as exceptions to their gender-yet still women and therefore never quite as competent or as committed as the men-harassment enables men to continue to define their work (and themselves) in masculine terms.

In this analysis, hostile work environment harassment is an endemic feature of the workplace that is both engendered by, and further entrenches, the sex segregation of work. ${ }^{407}$ In Carroll Brodsky's terms, harassment provides male workers "a mechanism for achieving exclusion and protection of privilege" in connection with work. ${ }^{403}$ Motivated by both material considerations and equally powerful psychological ones, harassment provides a means for men to mark their jobs as male territory and to discourage any women who seek to enter. By keeping women in their place in the workplace, men secure superior status in the home, in the polity, and in the larger culture as well.

Contrary to many prevailing assumptions, workplace harassment is not a mere reflection of unequal gender relations that have already been created

406. SCHROEDEL, supra note 16 , at 20-21.

407. There is, by now, a voluminous literature on the link between a group's numerical underrepresentation (or "token" status) in an occupation or job and the incidence of stereotyping, discrimination, and harassment that the token group experiences from the dominant group. Rosabeth Moss Kanter's 1977 study was one of the first to theorize this link in the context of gender. See KANTER, supra note 130, at 206-42. Since then, numerous scholars have examined this link and explored its ramifications. See, e.g., Brief for Amicus Curiae American Psychological Association in Support of Respondent at 4, Price Waterhouse v. Hopkins, 490 U.S. 228 (1989) (No. 87-1167) (summarizing psychological research finding that women who work in settings in which they comprise $15 \%$ or less of the population are more likely than others to experience sex discrimination, that the discrimination is more intense, and that such "women are likely to be penalized [in work performance evaluations], especially when they act in ways perceived as violating sex-related expectations"); Madeline Heilman, The Impact of Situational Factors on Personnel Decisions Concerning Women: Varying the Sex Composition of the Applicant Pool, 26 ORG. BEHAV. \& HUM. PERF. 386, 393 (1980) (describing a study showing that personnel decisions concerning women will be less favorable when women represent $25 \%$ or less of the total pool). But cf. Janice Yoder, Rethinking Tokenism: Looking Beyond Numbers, 5 GENDER \& SOC'Y 178, 180-83 (1991) (suggesting that this literature does not imply, in gender-neutral fashion, that men who occupy token status in female-dominated jobs will experience comparable levels of harassment and discrimination).

408. BRODSKY, supra note 70 , at 4. 
elsewhere, such as in the domestic sphere. ${ }^{409}$ The problem is not that men are not yet accustomed to working alongside women as equals and therefore revert to hierarchical and abusive relations learned in other settings. ${ }^{* 10}$ It is, instead, that by portraying women as less than equal at work, men can secure superior jobs, resources, and influence-all of which afford men leverage over women at home and everyplace else. Work and workplace relations are active shapers of gender difference and identity, and harassment is a central mechanism through which men preserve their work and skill as domains of masculine mastery. ${ }^{411}$

409. One of the most prominent theoretical models for sex-based harassment in the social science literature is called "sex-role spillover theory." Like sexual desire-dominance theory, which is its close cousin, sex-role spillover theory defines sex-based harassment in terms of sexual objectification. According to this theory, sexual harassment occurs because male workers improperily carry with them into the workplace gendered role expectations for women-most notably. sexual ones-that have already been formed in other realms of existence, such as domestic life. As Barbara Gutek, the inventor of this theory. explained:

Sex-role spillover denotes the carryover of gender-based expectations into the workplace. Among the characteristics assumed by many to be associated with femaleness (such as passivity. loyalty, emotionality, nurturance) is being a sex object. . . . This aspect of sex-role spillover. the sex-object aspect, is most relevant to the study of sex at work.

Sex-role spillover occurs when women, more than men in the same work roles, are expected to be sex objects .... What is equally important is the fact that there is no strongly held comparable belief about men. . . . [T]he cluster of characteristies that are usually associated with the male personality do not include a sexual component. Rather the stereotype of men revolves around the dimension of competence and activity. ... Sex-role spillover, thus, introduces the view of women as sexual beings in the workplace. but it simply reinforees the view of men as organizational beings-"active, work-oriented."

Barbara A. Gutek, Understanding Sexual Harassment at Work, 6 NOTRE DAME J.L ETHICS \& PUB. POL'Y $335,352-53$ (1992) (footnotes omitted). In my view, sex-role spillover theory is correet insofar as it emphasizes that workplace harassment seeks to portray women in terms that conflict with the image of a competent, committed worker. Nonetheless, I believe sex-role spillover theory is fundamentally flawed, for it posits that harassment occurs because male workers innocently transpon into the workplace gender-stereotyped attitudes towand women that they have leamed elsewhere. In earlier work. I cnticized the notion that the workplace is a passive reflector of gender inequalities already created in prior realms of life. See Schultz, supra note 210, at 1816-39. In addition, as this Article emphasizes, to the extent that sex-role spillover theory joins the sexual desire-dominance paradigm in emphasizing the way harassment portrays women as sexual objects, the theory is too limited. In the alternative account that I depict. men's advantage in numerous spheres of life depends on their superior status in the workplace: men's status as superior wage earners and possessors of masculine work competence is also central to mainstream definitions of masculinity. Thus, it serves men's interests to monopolize the most highly rewarded forms of work for themselves, and hostile work environment harassment provides a mechanism for doing so. In this analysis, wage work and work relations are not mere reflectors of gendered roles created elsewhere; they are important institutions for reproducing both gender inequality and gender identity.

410. Indeed, in at least one study, the women workers interviewed noted that the harassment they experienced at the hands of their male coworkers was different-and worse-than the treatment men direct at women in other contexts. See Nancy DiTomaso. Sexuality in the Workploce: Discrimination and Harassment, in THE SEXUALITY OF ORGANIZATION 71 (Jeff Heam et al. eds.. 1989). As DiTomaso writes:

[The harassment observed in a manufacturing firm] was not "nomal" behaviour between men and women. In fact, the women who commented on their experiences in this regard were quite clear that the men in the plant acted differently than they would if they interacted with these women in any other context. Their behaviour, in other words, was very much relaled to the work context itself. Id. at 81 .

411. For sources discussing hostile work environment harassment along these lines, see Peggy Crull, Searching for the Causes of Sexual Harassment: An Examination of Two Protorypes. in HIDDEN ASPECTS OF WOMEN's WORK 225 (Christine Bose et al. eds., 1987); Irene Padavic, The Re-Creation of Gender in 


\section{B. The Competence-Undermining Function of Hostile Work Environment Harassment}

We should reconceptualize hostile work environment harassment to acknowledge its crucial connection to job segregation by sex. We should recognize that the central function of such harassment is to preserve the masculine image and male-dominated composition of favored types of work. The definition of a hostile work environment should be broadened to cover all conduct that is rooted in gender-based expectations-not simply conduct that is sexual in nature. Experience teaches, however, that we should go further: To render visible many of the nonsexual forms of harassment that remain hidden, we should also recognize that much of the behavior that creates a hostile work environment is conduct that has the purpose or effect of undermining the perceived or actual competence of women (and some men) who threaten the idealized masculinity of those who do the work. ${ }^{412}$ By engaging in hostile work environment harassment, incumbent male workers lay claim to certain forms of work and the competence entailed as specifically masculine forms of labor.

Such a competence-centered account creates a more complete understanding of the kinds of hostility experienced by women at work, particularly in nontraditional settings. Cases brought by such women, including many of the cases already examined in this Article, reveal that a core element of their harassment is conduct having the aim or effect of undermining their work competence. Sometimes this conduct assumes a blatant form. As we have seen, many supervisors or coworkers openly question a woman's right to hold the job at all: They tell her she is not cut out for the work, ${ }^{413}$ inform her that

a Male Workplace, 14 SYMBOLIC INTERACTION 279 (1991); Barbara Reskin, Bringing Men Back In: Sex Differentiation and the Devaluation of Women's Work, 2 GENDER \& SOC'Y 58 (1988); Yoder, supra note 407; and Kristen R. Young, Ladies, Flirts, and Tomboys: Strategies for Managing Sexual Harassment in an Underground Coal Mine, 19 J. CONTEMP. ETHNOGRAPHY 396 (1991).

412. Although it is conceivable that, in some settings, women might seek to protect the perceived femininity of their work from incursion by men, such a reaction is unlikely to be widespread-not because women are more virtuous than men, but because men and women's structural incentives with respect to their work are not symmetrical. Whereas men's work and work competence are highly valued, women's are not. Thus it is not surprising that numerous studies have found that men who occupy token status in female-dominated work settings do not experience hostile work environment harassment comparable to that encountered by their female counterparts working in male-dominated settings. See, e.g., Yoder, supra noto 407, and studies cited therein; see also ROSEMARY PRINGLE, SECRETARIES TALK 78-82 (Verso 1989) (1988) (discussing the experience of male secretaries working for female supervisors); CHRISTINE L. WILLIAMS, GENDER DifFERENCES AT WORK: WOMEN AND MEN IN NONIRADITIONAL OCCUPATIONS 88-130 (1989) (discussing the experience of male nurses). Some exceptions no doubt exist. See, e.g., Jane Gross, Now Look Who's Taunting, Now Look Who's Suing, N.Y. TIMES, Feb. 16, 1995, § U, at I (describing a hostile work environment case brought by male employees of a Jenny Craig weight-loss center, who claimed that their female supervisor forced them to perform traditionally male activities, like changing tires, as part of a general campaign of gender harassment).

413. See, e.g., Stacks v. Southwestern Bell Yellow Pages, Inc., 27 F.3d 1316, 1318 (8th Cir. 1994) (reporting statements by a supervisor such as, "[T]here isn't a woman alive that can make it with Yellow Pages"); Lipsett v. University of Puerto Rico, 864 F.2d 881, 905 (1st Cir. 1988) (reporting that the head 
she should be at home with her children, ${ }^{4 / 4}$ or greet her with a "Men only" $\operatorname{sign}^{415}$ or equally graphic announcement that she is unwelcome. ${ }^{416}$ More typically, the men verbally demean a woman's competence or ability to do the job, the content of the denigration varying with the type of work. Sometimes, it takes the form of belittling a woman's physical prowess, as in firefighting and corrections. ${ }^{417}$ Sometimes, it takes the form of disparaging her technical competence, as in the trades, sciences, or medicine. ${ }^{.18}$ Sometimes, it takes the form of denigrating her intellectual achievement, as in the academy. ${ }^{419}$ Sometimes, it takes the form of questioning her capacity for adequate aggressiveness, as in police work or sales. ${ }^{420}$ Sometimes, it takes the form of characterizing her as overly aggressive or abrasive, as in law, management, or other elite professions. ${ }^{421}$ Sometimes, it takes the form of simply pronouncing her generally incompetent or unproductive. ${ }^{422}$ And, all too often,

of a surgery program and male surgery residents harassed female surgery residents by questionıng women's capacity to be surgeons at all); Sassaman v. Heart City Toyota. 879 F. Supp. 901.909 (N.D. Ind. 1994) (noting that a car saleswoman was told women are not cut out to be car salesmen).

414. See, e.g., Sassaman, 879 F. Supp. at 909 (reporting that a car saleswoman was told that she should be home with her children); Jenson v. Eveleth Taconite Co., 139 F.R.D 657, 663 (D. Minn. I991) (reporting the same with respect to female iron miners); Altschuler v. Walters, 34 Far Empl. Prac. Cas. (BNA) 522, 524 (E.D. Pa. 1983) (reporting the same with respoet to a female speech pathologist); $c f$. Morgan v. Hertz Corp., 542 F. Supp. 123, 126 (W.D. Tenn. 1981) (reporting that a female car rental manager was told "a woman's place [is] in the kitchen"), aff"d sub nom. Sones-Morgan v. Henz Corp.. 725 F.2d 1070 (6th Cir. 1984).

415. See Robinson v. Jacksonville Shipyards, Inc., 760 F. Supp. 1486. 1498 (M.D. Fla. 1991).

416. See, e.g., Wand v. City of Streetsboro, No. 95-3838, 1996 U.S. App. LEXIS 19085, al -2 (6th Cir. June 24, 1996) (reporting that a woman found a dead rat in her maibox): Waltman v. Intemational Paper Co., 875 F.2d 468, 471 (5th Cir. 1989) (reporting that used tampons were hung on female employees' lockers); Hansel v. Public Serv. Co., 778 F. Supp. 1126, 1129 (D. Colo. 1991) (reporting thal the plaintiff was confronted in the restroom by a coworker holding a hangman's noose).

417. See, e.g., Sims v. Montgomery County Comm'n, 766 F. Supp. 1052, 1066 (M.D. Ala. 1990) (corrections); Downum v. City of Wichita, 675 F. Supp. 1566, 1570 (D. Kan. 1986) (firefighting); Berkman v. City of New York, 580 F. Supp. 226, 234 (E.D.N.Y. 1983) (firefighting). aff $d .755$ F.2d 913 (2d Cir. 1985).

418. See, e.g., Lipsett. 864 F.2d at 905 (surgery residency): Jensvold v. Shalala. 829 F. Supp. 131.134 (D. Md. 1993) (medical research); Davis v. Boeing Helicopter Co., No. 88-0281, 1990 U.S. Dist. LEXIS 11990, at *7-8 (E.D. Pa. Sept. 12, 1990) (aircraft repair); Hallquist v. Max Fish Plumbing \& Healing Co.. No. 85-1965-C, 1987 WL 15878, at *2 (D. Mass. Aug. 14. 1987) (plumbing). aff'd sub nom. Hallquist v. Local 276, Plumbers \& Pipefitters Union, 843 F.2d 18 (Ist Cir. 1988).

419. See, e.g., King v. Board of Regents of the Univ. of Wis. Sys., 898 F.2d 533. 536 (7th Cir. 1990) (assistant professorship); Jensvold, 829 F. Supp. at 135 (research fellowship): Garvey v. Dickinson College. 775 F. Supp. 788, 793 (M.D. Pa. 1991) (assistant professorship).

420. See, e.g., Lenihan v. City of New York, 636 F. Supp. $998.1002-03$ (S.D.N.Y. 1986) (police work); EEOC v. Sears, Roebuck \& Co., 628 F. Supp. 1264, 1308 (N.D. Ill. 1986) (commission sales), aff 'd. 839 F.2d 302 (7th Cir. 1988); cf. Stacks v. Southwestem Bell Yellow Pages, Inc., 27 F.3d 1316. 1318 (8th Cir. 1994) (quoting a sales supervisor as stating "[T]here isn't a woman alive who can make it with Yellow Pages").

421. See, e.g., Price Waterhouse v. Hopkins, 490 U.S. 228, 234-35 (1989) (accounting parnership); Ezold v. Wolf, Block, Schorr \& Solis-Cohen, 983 F.2d 509. 544 (3d Cir. 1993) (law firm partnershup): Ramsey v. City of Denver, 907 F.2d 1004, 1010 (10th Cir. 1990) (engineering); Seligson v. Massachusetts Inst. of Tech., 677 F. Supp. 648, 651 (D. Mass. 1987) (university alumni association director): Petrosky v. Washington-Greene County Branch Pa. Ass'n for the Blind, 663 F. Supp. 821,823 (W.D. P2. 1987) (nonprofit management), aff'd, 845 F.2d 1014 (3d Cir. 1988).

422. See, e.g., Heim v. Utah, 8 F.3d 1541, 1546 (10th Cir. 1993): Scoll v. Sears. Rocbuck \& Co.. 798 F.2d 210, 215 (7th Cir. 1986); Davis, 1990 U.S. Dist. LEXIS 11990, at *7-8: Graham v. Amencan Airlines 
it takes the form of calling her dumb, stupid, or worthless:423 "You're a woman, what do you know?"424

Perhaps even more dangerous than such verbal denigration of women's competence, men can take actions that convert those statements into self-fulfilling prophesies. As the cases already analyzed in this Article reveal, there are diverse methods of subverting a woman's perceived or actual competence; the form of the conduct again varies with the occupational setting. Sometimes, it takes the form of deliberate sabotage of a woman's work performance, such as stealing a policewoman's case files, ${ }^{425}$ informing a lab worker that faulty equipment is sound, ${ }^{426}$ falsifying medical records to make it appear as though a female surgery resident made an error, ${ }^{427}$ or simply assigning her tasks that are impossible to accomplish. ${ }^{428}$ Sometimes, it takes the form of denying a woman adequate training, assignments, or other opportunities to learn a job fully, ${ }^{429}$ refusing to mentor her, or ostracizing her

Inc., 731 F. Supp. 1494, 1497 (N.D. Okla. 1989).

423. See, e.g., Gross v. Burggraf Constr. Co., 53 F.3d 1531, 1543 (10th Cir. 1995) (female truck driver referred to as "dumb"); Cross v. Alabama Dep't of Mental Health \& Mental Retardation, 49 F.3d 1490, 1497 (11th Cir. 1995) (psychiatric facility employees referred to as "rather dumb," "stupid," or "just a woman"): Steiner v. Showboat Operating Co., 25 F.3d 1459, 1463 (9th Cir. 1994) (female blackjack dealer referred to as "dumbass woman"); Cronin v. United Serv. Stations, Inc., 809 F. Supp. 922, 925 (M.D. Ala. 1992) (female convenience store manager referred to as a "dumb, old stupid woman"); Halasi-Schmick v. City of Shawnee, 759 F. Supp. 747, 750 (D. Kan. 1991) (female firefighter referred to as a "dumb blonde"); Harris v. Forklift Sys., Inc., 60 Empl. Prac. Dec. (CCH) q 42,070, at 74,249 (M.D. Tenn. 1990) (rental manager referred to as a "dumb ass woman"), aff'd, 976 F.2d 733 (6th Cir. 1992) (per curiam), rev'd, 510 U.S. 17 (1993); Delgado v. Lehman, 665 F. Supp. 460, 464 (E.D. Va. 1987) (EEOC specialist subjected to denigrating comments by a naval official about "dumb females working for him who couldn't read or write").

424. Harris, 60 Empl. Prac. Dec. (CCH) at 74,245 (quoting a rental manager).

425. See, e.g., Andrews v. City of Philadelphia, 895 F.2d 1469, 1473 (3d Cir. 1990).

426. See, e.g., Hosemann v. Technical Materials, Inc., 554 F. Supp. 659, 663 (D.R.I. 1982).

427. See, e.g., Lipsett v. University of Puerto Rico, 864 F.2d 881, 910 (1st Cir. 1988).

428. See, e.g., Holmes v. Razo, No. 94C50405, 1995 U.S. Dist. LEXIS 10599, at *5 (N.D. Ill. July $18,1995)$ (reporting the plaintiff's allegation that her supervisor "doubled [her] workload to an impossible level"); Beeman v. Safeway Stores, Inc., 724 F. Supp. 674, 675 (W.D. Mo. 1989) (reporting an allegation by a female grocery store manager that her boss harassed her by "making daily checks upon her work, ... belittling her performance, ... reprimanding her in meetings that lasted up to three hours, ... making long lists of things for her to do,... [and] asking her to accomplish work tasks that were impossible to accomplish within the allotted time"); Accardi v. Superior Court, 21 Cal. Rptr. 2d 292, 297 (Ct. App. 1993) (reporting a female police officer's allegation that her department undercut her performance by "deliberately overburdening her with double work assignments; denying assistance when she requested it; [and] deliberately circumventing established procedures when she was assigned to duty as a court officer in order to make her work more difficult").

429. See, e.g., Heim v. Utah, 8 F.3d 1541, 1543 (10th Cir. 1993) (involving a construction technician who claimed that she was denied the opportunity to obtain construction experience in the field); Ezold $v$. Wolf, Block, Schorr \& Solis-Cohen, 983 F.2d 509, 540-41 (3d Cir. 1993) (involving a law firm associato who claimed that she was denied the opportunity to work on large complex cases and was subsequently denied partnership on the ground that she lacked the capacity to handle such matters); Scott v. Scars, Roebuck \& Co., 798 F.2d 210, 212 (7th Cir. 1986) (involving an auto mechanic trainee who claimed that she was denied the ability to learn to do brake repair and was subsequently fired on the ground that sho was not productive at such work); Danna v. New York Tel. Co., 752 F. Supp. 594, 603 (S.D.N.Y. 1990) (involving a telephone operator who was promoted to repair service technician and assigned to train with a technician who would not let her do any of the work herself, and was later downgraded to a clerical job); Downum v. City of Wichita, 49 Fair Empl. Prac. Cas. (BNA) 162, 165 (D. Kan. 1986) (involving a female firefighter who claimed she was rushed through training to be a dispatcher and made to do the job before 
from the informal networks through which crucial job skills are passed on. ${ }^{430}$ Sometimes, it takes the form of evaluating a woman's performance by sexist and differential standards, ${ }^{431}$ or requiring her to perform service-oriented tasks that are outside her job description, such as cleaning, ${ }^{432}$ serving coffee, ${ }^{433}$ or providing secretarial support. ${ }^{434}$ Sometimes, it takes the form of denying a woman the privileges and perks needed to succeed on the job, as, for example, withholding from saleswomen or managers the right to deal with clients or the use of a company car, credit card, or office. ${ }^{435}$ Sometimes, it takes the form of assigning a woman duties below her skill level or extending her forms of "help" that signal she is incompetent to perform the simplest of tasks. ${ }^{436}$ Sometimes, it takes the form of gender-neutral acts of physical assault, verbal taunts, or other hazing in order to demoralize a woman psychologically or to threaten or intimidate her physically. ${ }^{37}$ And, far too

she was ready); Berkman v. City of New York, 580 F. Supp. 226, 233 (E.D.N.Y. 1983) (involving female firefighters who were inadequately trained by officers who instead set out deliberately to undermune their physical capacity to do the job, and then (erminated them at the end of their probation period), aff'd, 755 F.2d 913 (2d Cir. 1985); see also supro notes 363-369 and accompanying text.

430. See, e.g., Jensvold v. Shalala, 925 F. Supp. 1109,1117 (D. Md. 1996).

431. See, e.g., Price Waterhouse v. Hopkins, 490 U.S. 228. 235 (1989) (involving a woman denied an accounting partnership on the ground that she was too "macho" and who was advised to "walk more femininely, talk more femininely, dress more feminine!y. wear make-up. have her hair styled. and wear jewelry"); Petrosky v. Washington-Greene County Branch Pa. Ass'n for the Blind, 663 F. Supp. 821, 822 (W.D. Pa. 1987) (involving a nonprofit manager who was fired on the ground that she was overly abrasive and who was advised to take a "Dale Camegie course"), aff'd, 845 F.2d 1014 (3d Cir. 1988).

432. See, e.g., Sassaman v. Heart City Toyota, 879 F. Supp. 901,908 (N.D. Ind. 1994) (involving a car saleswoman who was required to clean a popcom machine).

433. See, e.g., Harris v. Forklift Sys., Inc., 60 Empl. Prac. Doc. (CCH) 9 42,070, al 74,247 (M.D. Tenn. 1990) (involving a rental manager who was made to serve coffee during meelings with clients). aff 'd, 976 F.2d 733 (6th Cir. 1992) (per curiam), rev'd, 510 U.S. 17 (1993).

434. See, e.g., Smith v. Texas Dep't of Water Resources, 818 F.2d 363. 365 (Sth Cir. 1987) (involving a female topographer who was required to relieve her boss's secrelary. twice a day, when the secretary was out on break); Halasi-Schmick v. City of Shawnee, 759 F. Supp. 747, 751 (D. Kan. 1991) (involving a female firefighter who was made to relieve a department secretary when the secretary was out).

435. See, e.g., Rabidue v. Osceola Ref. Co., 805 F.2d 611. 624 (6th Cir. 1986) (Keith. J., concurring in part and dissenting in part) (involving a female sales manager at a refining company who was nol permitted to take customers to lunch or to have use of a company credil card): Sassaman. 879 F. Supp. at 908-09 (involving a car saleswoman who was not permitted to take customers on demonstration rides or to use the computer system for locating cars); Kulp v. Dick Horrigan VW. Inc.. 63 Fair Empl. Prac. Cas. (BNA) 1185 (E.D. Pa. 1994) (involving a car saleswoman who was denied perks and pnvileges granted salesmen); Harris, 60 Empl. Prac. Dec. (CCH) at 74,246-47 (involving a rental manager who was denied her own office as well as the use of a company car); see also King v. Board of Regents of the Univ. of Wis. Sys., 898 F.2d 533, 535 (7th Cir. 1990) (involving an assistant professor who claimed that the director of her program limited her research time, assigned her a burdensome teaching load, and subjected her to excessive teaching evaluations).

436. See, e.g., Davis v. Boeing Helicopter Co., No. 88-0281, 1990 U.S. Dist. LEXIS 11990, al *10 (E.D. Pa. Sept. 12, 1990) (involving a female aireraft assembler who was promoted to electncian and who claimed that her supervisor "harassed her and made it impossible for her to complete her work by checking her progress every few minutes"); Egger v. Local 276, Plumbers \& Pipefitters Union, 614 F. Supp. 795, 798 (D. Mass. 1986) (involving a joumeyman plumber assigned "low-level, demeaning" work below her skill level), aff'd sub nom. Hallquist v. Local 276, Plumbers \& Pipefitters Union. 843 F.2d 18 (1st Cir. 1988).

437. See, e.g., Fuller v. City of Oakland, 47 F.3d 1522, 1526 (9th Cir. 1995) (involving a policcwoman who was ostracized by her fellow officers, thereby threatening her safety because visible isolation on the beat subjects an officer to more danger); Reed v. Shepard, 939 F.2d 484. 486 (7th Cir. 1991) (involving 
frequently, it even takes the form of discrediting her mental stability or sanity. ${ }^{438}$

Of course, these nonsexual forms of harassment frequently are accompanied by more sexual ones, such as crude sexual overtures, or sexual taunting and mockery. Such overtly sexual harassment, like its less sexual counterpart, often is designed to undermine a woman's outward image of competence and sense of self-confidence as a worker. Sometimes, such conduct takes the form of singling out a woman as the object of sexual attention, as in work roles in which a woman's heightened attractiveness would be inconsistent with the image of competent professionalism (such as in medicine or academia). ${ }^{439}$ Other times, men may use sexual overtures or taunting as a way of branding a woman as inferior by brandishing their superior masculine strength, as in settings in which physical virility is a central part of the masculine image of the job (such as in police or construction work) ${ }^{440}$ In such settings, male workers use sexuality as "a technology of sexism"441

a civilian jailer who was punched and kicked, handcuffed and maced, and whose head was shoved into a toilet); Andrews v. City of Philadelphia, 895 F.2d 1469, 1474 (3d Cir. 1990) (involving policewomen who had lime placed in their uniforms, severely burning their skin); Hansel v. Public Serv. Co., 778 F. Supp. $1126,1128-29$ (D. Colo. 1991) (involving a lone female auxiliary tender at a power plant who was "hit . . . over the head with a crescent wrench with such force that [her hard hat] was dented," had a large bolt dropped on her that nearly hit her head, had her arms held by one coworker while another sexually assaulted her, had her work gloves filled with bathroom cleaner and lime powder, and was confronted with a hangman's noose and told "it would be better if she just killed herself"); Weinsheimer v. Rockwell Int'] Corp., 754 F. Supp. 1559, 1561 (M.D. Fla. 1990) (involving a female thermal protection inspector who was shoved into a file cabinet, had a knife held to her throat, and was threatened with other physical violence), aff'd, 949 F.2d 1162 (11th Cir. 1991); Egger, 644 F. Supp. at 798 (involving a plumber who had cockroaches placed in her hair and pants and was confronted with a decapitated cat).

438. See, e.g., Jensvold v. Shalala, 829 F. Supp. 131, 134 (D. Md. 1993) (involving a postdoctoral fellow at the National Institute of Mental Health who was ordered into psychotherapy by a supervising researcher); Vermett v. Hough, 627 F. Supp. 587, 593 (W.D. Mich. 1986) (involving a state policewoman who was subjected to repeated counseling sessions as a condition for keeping her job); Kyriazi y. Westem Elec. Co., 461 F. Supp. 894, 899 (D.N.J. 1978) (involving an engineer who was fired when she complained of discrimination instead of complying with her supervisor's ultimatum to seek psychiatric help), aff'd, 647 F.2d 388 (3d Cir. 1981).

439. See, e.g., King, 898 F.2d at 534-35 (reporting that an assistant dean leered at the plaintiff assistant professor and made remarks about her body that were blatant enough for other faculty to comment upon); Lipsett v. University of Puerto Rico, 864 F.2d 881, 888 (1st Cir. 1988) (reporting that male surgery residents posted sexual nicknames for the plaintiff surgery resident and explicit drawings of her body on the bulletin board); Jew v. University of Iowa, 749 F. Supp. 946, 949 (S.D. Iowa 1990) (reporting that a faculty member publicly speculated about the plaintiff doctor's alleged affair with a fellow doctor and referred to her as a "slut").

440. See, e.g., Sorlucco v. New York City Police Dep't, 888 F.2d 4, 6 (2d Cir. 1989) (reporting that a policewoman was sexually assaulted by a fellow officer, who took her service revolver, aimed it at her head, and sodomized her after firing a bullet through her mattress); Hall v. Gus Constr. Co., 842 F.2d 1010 , 1012 (8th Cir. 1988) (involving female flagpersons on a construction site who were subjected to numerous types of physical assault, including an act in which "[m]ale crew members would comer the women between two trucks, reach out of the windows and rub their hands down the women's thighs"); see also Hansel, 778 F. Supp. at 1128 (involving a power plant worker who had her arms held by one coworker while another sexually assaulted her).

441. Katherine M. Franke, What's Wrong with Sexual Harassment, 49 STAN. L. REv. 691,762 (1997). Unlike my account, Franke's analysis does not directly highlight the competence-undermining function of sexual forms of hostile work environment harassment. Instead, she focuses on the fact that such sexualized conduct enforces gender-based stereotypes. See id. at 747, 763. As her examples reveal, however, sexuality 
aimed at undermining a woman's work competence.

Contrary to the image of harassment as a top-down phenomenon, it is not only women subordinates who experience such efforts to undermine their competence. As the earlier discussions of Reynolds v. Atlantic City Construction Center ${ }^{442}$ and Rabidue v. Osceola Refining Co. ${ }^{43}$ illustrate, women higher-ups also confront challenges to their power and efforts to subvert their performance by male subordinates. ${ }^{\text {th }}$ Indeed, many men may have particular difficulty submitting to the authority of a female boss. A competence-centered theory, in addition to explaining the harassment directed at women who work in male-dominated jobs, also helps clarify some of the forms of harassment experienced by women in predominantly female jobs. Like their nontraditionally employed counterparts, women in more traditional settings also experience nonsexualized forms of harassment that are geared toward undermining their competence or intelligence as workers. Often, they are subjected to demeaning forms of authority, humiliation, and abuse—objectified, not necessarily as sexual objects, but as fools, children, or

is an effective tool for reinforcing prescribed gender roles in some work setuings precisely because male workers can use sexual conduct to undermine wornen's competence and, hence, mark them as infenor workers not fit to hold more highly rewanded jobs.

Franke's discussion of Steiner v. Showboat Operating Co., 25 F.3d 1459 (9th Cir. 1994). Illustrates this point. In Steiner, the male supervisor of a Las Vegas casino harassed the first female floor person by calling her such things as "dumb fucking broad," "cunt," and "fucking cunt" and yelling at her in front of customers and coworkers, "You are not a fucking floor man [her job]... You are a fucking casino host. ... Why don't you go in the restaurant and suck their dicks . . [?]" Id. al 1461. Franke concludes that

what made [this conduct] sex discrimination, was not, as the court found, the sexual content of the conduct, but that [the supervisor] used sexual harassment to put Steiner in her "proper place," thereby diminishing her authority and role as a floor person. In this sense, the sexual harassment feminized Steiner, rendering her less competent and more sexual.

Franke, supra, at 764 . Although Franke stresses that the case shows how sexual conduct may reinforee prescribed notions of masculinity and femininity, her own analysis of the case suggests that it does so by associating male sexuality with the required work competence and female sexuality with a lack of such competence.

442. 53 Fair Empl. Prac. Cas. (BNA) 1852 (D.N.J. 1990), aff'd. 925 F.2d 119 (3d Cir. 1991 ). discussed supra text accompanying notes 183-196.

443. 805 F.2d 611 (6th Cir. 1986), discussed supra text accompanying notes 380-384.

444. Nicole Gueron has referred to such harassment of superiors by their subordinates as "bottom-up harassment." See Nicole L. Guerron, Strengthening "The Weakest Case of All": Expanding Title VII Sexual Harassment Doctrine To Include "Bottom-Up" Harassment (May 16. 1995) (unpublished masuscript, on file with author). There are many additional examples of such bottom-up harassment. See. e.g.. Beardsley v. Webb, 30 F.3d 524, 528 (4th Cir. 1994) (involving a female police lieutenant whose squad became insubordinate, "bypassing the chain of command and reporting only to [the first lieutenant]." who. in tum. bypassed the plaintiff "to give orders directly to her deputies, hampering her efforts to run her shift"); Hill v. K-Mart Corp., 699 F.2d 776, 777-78 (5th Cir. 1983) (involving a male employee who refused to obcy orders from a female retail manager, and whose company failed to suppon the manager's authority): Ott v. Perk Dev. Corp., 846 F. Supp. 266, 270 (W.D.N.Y. 1994) (involving an employec who placed a Penthouse magazine in his female supervisor's notebook): Kirkland v. Brinias, 741 F. Supp. 692, 694 (E.D. Tenn. 1989) (involving a 50-year-old busboy who threatened to kill one waitress and physically foughi with another when she asked him to clear tables, proclaiming that he refused to take orders from a woman). aff'd, 944 F.2d 905 (6th Cir. 1991); Anderson v. Chicago Hous. Auth., No. 86-C-0449. 1988 U.S. Dist. LEXIS 14454, at *3-4 (N.D. Ill. Dec. 20, 1988) (involving a supervisor who instrueted the plaintiffs subordinates to give her orders). 
creatures to be exploited and controlled. ${ }^{445}$ Furthermore, when such women step out of place by refusing to provide sexual favors or otherwise challenging male authority and control, they are often punished through nonsexual measures to subvert their performance or get them fired. ${ }^{446} \mathrm{~A}$ competence-centered model focuses on the gendered nature of this process of punishment, rather than on the advances or abuses of authority that preceded it.

To the extent that hostile work environment harassment is motivated by a clear and conscious purpose, that goal is not always clear. Sometimes, the harassment seems clearly calculated to drive women away from the job. ${ }^{447}$

445. See, e.g., EEOC v. Hacienda Hotel, 881 F.2d 1504, 1507-08 (9th Cir. 1989) (involving hotel housekeepers who were subjected to demeaning remarks on account of their pregnancies, including comments that they were "too fat to clean rooms" and that the supervisor did not like "stupid women who have kids"); Cronin v. United States Serv. Stations, Inc., 809 F. Supp. 922, 925 (M.D. Ala. 1992) (involving a female convenience store manager who was belittled as a "dumb, old stupid woman"); Cline v. General Elec. Capital Auto Lease, Inc., 757 F. Supp. 923, 925-26 (N.D. Ill. 1991) (involving female collections agents whose boss belittled their dress and appearance, slapped and hit them, and confiscated personal credit cards); Delgado v. Lehman, 665 F. Supp. 460, 464 (E.D. Va. 1987) (involving women office workers who were subjected to a naval official's pronouncement that he had "dumb females working for him who couldn't read or write").

446. See, e.g., McKinney v. Dole, 765 F.2d 1129, 1132 (D.C. Cir. 1985) (describing the grievances of an analyst who alleged that she was passed over for promotions as retaliation for filing sexual harassment complaints); Garvey v. Dickinson College, 775 F. Supp. 788, 792 (M.D. Pa. 1991) (involving a female professor who alleged that she was denied tenure as retaliation for reporting sexual harassment); Laughinghouse v. Risser, 754 F. Supp. 836, 843 (D. Kan. 1990) (involving a female branch manager who was subjected to an abrasive campaign to inhibit her job performance after she declined to spend the night with her district manager).

447. Numerous commentators have posited such a motive for harassment. See, e.g., MARTIN, supra note 209, at 10 (arguing that harassment experienced by women in male-dominated trades is "aimed at us simply because we are women in a 'man's job,' and its function is to discourage us from staying in our trades"); Wendy Pollack, Sexual Harassment: Women's Experience vs. Legal Definitions, 13 HaRV. WOMEN'S L.J. 35, 37-38 (1990) (making a similar argument). In some of the legal cases, this motivation seems clear. In one case, for example, a waitress who was promoted by a restaurant owner to be the maitre d' was subjected to a campaign of harassment to drive her away, including false accusations that she stole and drank on the job. Her tormentors went so far as to place wine bottles in her locker to substantiate the accusations. See Levendos v. Stern Entertainment, Inc., 909 F.2d 747, 749 (3d Cir. 1990). The gencral manager of the restaurant stated openly that she did not fit the mold for a maitre d' because she was a woman and boasted that she would not hold the job for long; a coworker stated that the chef admitted that "there was a plan to get rid of her, and replace her with a male friend of the chef." Id. at 749-50. Another case involved a conspiracy by supervisors and a coworker to drive away the lone woman on a 15-member building maintenance crew at a meat processing plant. See Olmer v. Iowa Beef Processors, 66 Fair Empl. Prac. Cas. (BNA) 843 (D. Neb. 1994). A high-level supervisor told the woman's immediate supervisor to give her the worst jobs in an effort to force her to quit, and the latter complied by, among other things, forcing her to perform high-up jobs even though he knew she was terrified of heights. Eventually, a coworker got her fired by yelling obscenities such as "fucking bitch," "slut," and "whore" directly in her face and physically thrusting his body against hers as she was working. Id. at 844-45. When she reached out with her open right hand to defend herself, he threw a temper tantrum and told her, "I just got your fucking job. You ain't going to be working here no more." Id. True to his prediction, the company fired the plaintiff on the ground that, in the case of an altercation, its policy was to fire the employee who initiated physical contact. See id. at 846; see also Thompson v. Arkansas Transp. Dep't, 691 F. Supp. 1201, 1203 (E.D. Ark. 1988) (involving a vendetta against the first female enforcement officer by the department heads, who openly admitted that they did not want more females employed as officers, assigned a roving commission to investigate her, and held an investigation resulting in findings of misconduct against her, findings that the court found demonstrably inaccurate and unworthy of belief); EEOC v. Protck of Albuquerque, 49 Fair Empl. Prac. Cas. (BNA) 1110, 1111 (D.N.M. 1988) (involving a general manager of a car detailing company who told a pregnant female shop foreman that "it would be embarrassing to 
At other times, it may serve to reconcile male workers to women's presence by marking the women as different and inferior workers who are less threatening competitors. ${ }^{448}$ At yet other times, it seems designed simply to punish a woman who has dared to transgress prescribed gender boundaries. Whatever the goal, what unites all these experiences is that women work in occupational environments that define their very womanhood as the opposite of what it takes to be a good worker.

\section{Reconceptualizing the Harassment of Women Workers}

The competence-centered account of harassment would return Title VII to its original and primary focus on dismantling job segregation by sex. Experience with opening traditionally male jobs has clarified the role of hostile work environment harassment in marking and maintaining certain work as appropriate for men only. As we have seen, a core component of such harassment is conduct designed to undermine a woman's competence; the harassment does not always consist of sexual advances or other sexually oriented conduct.

To reconceptualize harassment law, courts must recognize the linkages between job segregation by sex, hostile work environments, and notnecessarily-sexual, competence-undermining harassment. Berkman v. City of New York ${ }^{449}$ provides an inspiring example. Brenda Berkman and Zaida Gonzalez were members of a class of plaintiffs who had won a suit against the New York City to open firefighting positions to women. The cour in this earlier case had invalidated the required physical exam under Title VII and had ordered the city to devise a nondiscriminatory exam. Berkman and Gonzalez passed the new exam and completed the training academy with flying colors, but they were fired at the end of their probationary period. When the plaintiffs brought a second lawsuit to challenge their firing, the city argued that their performances were substandard. Judge Sifton found, instead, that the two

have a fat woman meet our customers," then switched her to work in an area where caustic chemical fumes accumulated, threatening the health of her fetus).

448. While some commentators have emphasized how harassment serves to wam or dnve women away from male-dominated jobs, others have emphasized its role in permitting men to reconcile themselves to the presence of women by incorporating them on inferior terms. See, e.g.. Marian Swerdlow, Men's Accommodations to Women Entering a Nontraditional Occupation: A Case of Rapid Transil Operatives. 3 GENDER \& SOC'Y 373, 374 (1989). Swerdlow concluded the following, on the basis of a four-year. participant-observation study of transit operators:

$[M]$ en as well as women developed accommodative pretices when "new women" amved. Although the men's job security was not threatened, their decply held belief in male supenonty was challenged by the increasing evidence that women could perform their jobs competently. They responded not by attempting to oust women through harassment. but by adapting collective interpretations of experience and practices that allowed them to preserve the ideology Id. of male supremacy while accepting the entrance of women.

449. 580 F. Supp. 226 (E.D.N.Y. 1983), aff'd, 755 F.2d 913 (2d Cir. 1985). 
women were subjected to retaliatory discrimination because of their sex and that a core component of the discrimination was a campaign to discredit their competence, which culminated in their termination. Indeed, the judge concluded that "the officers of the Department responsible for their training and evaluation ... . deliberately set out to re-examine Berkman's and Gonzalez' physical capacities to be firefighters. ${ }^{3450}$

Judge Sifton correctly perceived the origins of such discriminatory conditions in the desire to preserve firefighting as an all-male preserve. The judge began the analysis, powerfully, by recognizing how predictable it was that the first female firefighters to enter the department would experience harassment and discrimination:

What is first of all apparent... is that the Fire Department failed lamentably to prepare its officers and members for the extraordinary task of integrating women into its previously all-male ranks. ... Nothing was done to assure that the extraordinarily lax and generalized system of evaluating the progress of probationary firefighters was administered rigorously and concretely in the case of women probationers so as to avoid the introduction of prohibited discrimination in the evaluation and training to the women firefighters. ... [T] he Department did next to nothing to foresee and prevent retaliation and sexual harassment which was one obviously foreseeable response to the disruptions of everyday life in the workplace caused by women joining the fire force. ${ }^{451}$

Understanding that harassment was a predictable aftermath of attempting to integrate women into the fire department permitted the court to recognize, equally perceptively, how central the nonsexual forms of harassmentparticularly, differential training and evaluation-were to the campaign to drum Berkman and Gonzalez out of firefighting. In the true spirit of McKinney $v$. Dole ${ }^{452}$ the judge forcefully conveyed the notion that the nonsexual conduct was as important as the sexual misconduct to sabotaging the women's ambitions. This analysis in no way trivialized the more sexual harassment. Indeed, Judge Sifton began by acknowledging that "both Berkman and Gonzalez were subjected ... to extensive sexual abuse in the form of unimpeded hazing. "${ }^{\text {"453 }}$ The judge then went on to describe how Berkman was subjected to "crude sexual comments" in the form of graffiti and cartoons, and how Gonzalez had "prophylactic devices and a wet vibrator ... placed in her

450. Id. at 230 .

451. Id. at $230-31$.

452. 765 F.2d 1129 (D.C. Cir. 1985), discussed supra text accompanying notes 247-249, 296-298.

453. Berkman, 580 F. Supp. at 231. 


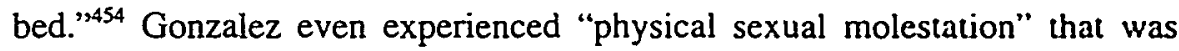
tolerated by the department. ${ }^{455}$

Yet the court's analysis did not end with these sexual overtures. Judge Sifton made clear that "the same discrimination that permitted these practices to occur and continue itself entered into the other more important matters at hand, namely the training of the applicants and their evaluations." ${ }^{\text {ns6 }}$ The judge first detailed how the male firefighters isolated the women from "the unique forms of communal living that are characteristic of the firefighters' workplace. ${ }^{.457}$ For example,

Berkman's bed was not made by the firefighters assigned this task as part of their regular duties. She received little help on cooperative tasks in the firehouse. A meal prepared by Gonzalez was thrown into the garbage by the men in her firehouse. Both were ... "put out of the meal," meaning that they were denied the opportunity to share in the traditional communal effort to use the cooking facilities of the firehouse to enjoy a common repast. ${ }^{458}$

Having recounted the exclusionary quality of day-to-day life in the firehouse, the court concluded that the inadequate training and evaluations that Berkman and Gonzalez had received were pan of this same hostile work environment, stating, "[I]t is clear that this intentional discrimination went beyond a failure to integrate the women into the workplace and, in fact, infected as well their evaluation and training to be firefighters." ${ }^{\text {ss }}$ Judge Sifton understood that the department's judgment that the wornen's performances were substandard was not only the product of a sex-biased evaluation process, but also the predictable (if not sought after) result of the department's own discriminatory failure to train women properly. According to the judge, "both women were faulted for performances easily corrected by training which they were denied." 460 Indeed, such opportunities were "deliberately withheld from them by company officers intentionally pursuing an effort to prove that the women lacked the basic capacity to be firefighters." 461

Although the content of the competence-undermining campaign was subtle, the court's frame of reference enabled it to discern the gender-based quality of the conduct involved. The judge's discussion is eye-opening. In one incident, for example, Berkman's supervising officer attributed her difficulty in

\footnotetext{
454. Id.

455. Id.

456. Id.

457. Id. at 232 .

458. Id.

459. Id.

460. Id.

461. Id.
} 
operating a power saw to insufficient upper-body strength. "[A]fter initial difficulties in operating the device relying only on the laconic explanation given her by the supervisor who later evaluated her," noted the court, "Berkman learned of a recognized technique approved at the Training Academy. ... Once advised of this technique, Berkman thereafter employed it successfully and, according to the uncontradicted evidence, has never encountered difficulties in starting the saw or operating it since." ${ }^{\mathbf{4 6 2}}$ Similarly, Berkman was accused of being unable to remove a hose nozzle that her male counterpart was able to remove. "Despite having performed this simple task numerous times before without difficulty (the nozzles are required by the Department to be only hand tight)," Berkman could not remove the nozzle by hand on this occasion and required a spanner to accomplish the task. ${ }^{463}$ She later discovered that, in violation of department regulations, someone had tightened the nozzle to such a degree that there was no way to unfasten it without a spanner. The court understood this act of work sabotage for what it was: part of the men's larger campaign to transform their pronouncement of Berkman and the other women's lack of competence to be firefighters into a self-fulfilling prophecy. ${ }^{464}$

The court also comprehended that, in Gonzalez's case, sexual assault and accusations of emotional instability were part of the men's plan to subvert her competence and drive her out of the ranks of firefighting: "Not only was Gonzalez subjected to the same litany of sexual harassment through comment, hazing, exclusion from the meals, and denial of the ordinary amenities of cooperative firehouse living as Berkman, Gonzalez was physically abused in a sexual manner and, in response to her complaints, vilified and defamed...."465 The physical advances, rather than signaling genuine sexual interest, served as a way of marking Gonzalez as too weak and defenseless to be a firefighter. Indeed, Judge Sifton noted that " $[w]$ hen, in response to [her] systematic mistreatment, she on one occasion lost control of her emotions [and cried], even that fact was recorded against her as evidence of [her unsuitability] for the job." ${ }^{\mathbf{4 6 6}}$ Her captain purportedly wrote her up for physical cowardice and emotional instability. ${ }^{467}$ To his credit, the judge refused to accept the department's characterization of Gonzalez as incompetent. Instead, in a moving passage, he commended her courage and commitment to her chosen calling:

462. Id. at 234.

463. Id. at 235.

464. See id.

465. Id. at $239-40$.

466. Id. at 240.

467. See id. at 240 n.18. 
Given the credible testimony at trial with respect to sexual harassment and discrimination to which she was subjected, what is surprising is not that Ms. Gonzalez was rated unsatisfactory on the few evaluations on which she received that rating on her re-evaluation at the Training Academy, but rather that she has had the courage to continue to pursue her goal of becoming a firefighter and learn as much as she plainly has about her chosen career. . . . If any good can come of this sad history of mistreatment, it arises from Ms. Gonzalez' courageous refusal to back down and the assurance that such conduct, now brought to light, need never again be repeated in the history of the City's Fire Department. ${ }^{468}$

Berkman exemplifies the kind of approach courts would bring to cases under a competence-centered paradigm. As we have seen, the court's evaluation of the evidence was framed from the outset by the judge's understanding of the difficulties that women who enter occupational turf long reserved for men are likely to encounter. Such an understanding was facilitated by the unique posture and claims of the case: Berkman was not a hostile work environment case, but rather a challenge to the plaintiffs' terminations in violation of an earlier court order. The court's involvement in the earlier pattern or practice case gave the judge an intimate understanding of the structural context of the women's firings; the judge had extensive knowledge about the fire department, its history, its culture, its image, and the attitudes of its leadership and its rank and file. The judge therefore understood the depth of the resistance to integrating women into the ranks of firefighting. From this frame of reference, the court perceived the campaign of harassment, not as an expression of the male firefighters' sexual needs, but rather as an attempt to police the gender boundaries of their calling against incursion from creatures considered too physically inept to uphold the image of the heroic firefighter. This perspective cast the nonsexual forms of harassment in as suspicious a light as the more sexually abusive forms and revealed the biases inherent in the plaintiff's training and evaluations. The court was able to perceive that all the harassment directed at the women was designed to challenge their capacity-and their entitlement-to become firefighters. This competencecentered understanding of harassment, in turn, revealed that any problems in the women's performance were a product of the discriminatory training and harassment the women had experienced because of their sex.

As Berkman illustrates, a competence-undermining account of hostile work environment harassment would help rectify the problems of underinclusiveness created by the prevailing sexual desire-dominance paradigm. By redirecting the courts' attention away from whether harassing conduct is sexual in nature and restoring Title VII's principal emphasis on whether such conduct makes it

468. Id. at $239-40$. 
more difficult for women to develop and express their capability as workers, the new account would aid many women who have been excluded from the protection of harassment law.

\section{AdDitional Advantages of the COMPETENCE-CENTEREd ACCOUNT}

The sexual desire-dominance paradigm has obscured more than women's gender troubles at work: It has also led the courts to overlook the problems faced by some men who suffer from harassment by male supervisors or coworkers. As this part shows, the competence-centered account creates a coherent framework for addressing claims of same-sex harassment. Rather than inquiring into whether the content or motivation underlying such harassment is sexual, the new account would investigate whether the harassment creates pressure to conform to the harassers' image of suitable manly competence for those who do the job. If so, the conduct is based on gender within the meaning of Title VII.

Just as the competence-centered account helps reveal the actionable features of male-on-male harassment, it also reduces the risks of prohibiting benign sexual expression that are present under the prevailing paradigm. The new account cautions against confusing gender-based harassment with mere talk about sex. Some forms of sexual expression in the workplace remain properly outside Title VII's purview because they do not involve the conscription of gendered work roles that is the statute's central concern.

\section{A. Revealing the Actionable Features of Male-on-Male Harassment}

Just as the heterosexual desire-dominance paradigm has rendered invisible some of the most debilitating forms of gender-based harassment and hostility experienced by women, it has also obscured some pernicious forms of such harassment experienced by men. If the published cases provide any indication, ${ }^{469}$ the most common form of harassment experienced by men may not involve, as the film Disclosure ${ }^{470}$ would suggest, female supervisors trying to extract sexual favors from their male subordinates. Instead, the most prevalent form of harassment experienced by men may be harassment directed at them by their male coworkers or supervisors in an attempt to force conformity to the dominant group's image of suitable masculinity for particular jobs. ${ }^{471}$

469. I have written elsewhere about the difficulty of drawing conclusions from published judicial decisions. See Vicki Schultz \& Stephen Petterson, Race, Gender, Work, and Choice: An Empirical Study of the Lack of Interest Defense in Title VII Cases Challenging Job Segregation, 59 U. CHI. L. REV. 1073, 1091 (1992).

470. DisClosure (Wamer Bros. 1994).

471. Glenngarry, Glen Ross might provide a better vehicle than Disclosure for understanding the type of hostile work environments experienced by some men. In the film version of David Mamet's play, see 
The competence-centered paradigm provides a helpful framework for analyzing such male-on-male harassment. As the account illuminates, men have a lot at stake in assuring a tight linkage between their work and their masculinity. It is crucial for many men to maintain control over the masculinized image of their work. ${ }^{472}$ If a job is to confer masculinity, it must be held by those who project the desired manliness. Thus, in these men's eyes, it is important to affirm that any woman who would be found in a "man's job" is neither as competent as a man, nor even a "real" woman. Indeed, nontraditionally employed women are often branded as lesbians, without regard to the accuracy of the label. ${ }^{473}$ Crossing the gender divide in an occupational sense is associated with crossing it in a sexual sense as well.

But women are not the only ones who can disrupt the link between work competence and masculinity. As historian Ava Baron has shown, for example, boys can do so also. ${ }^{47}$ The expression "Don't send a boy when you need to

GLENNGARRY, GLEN ROSS (New Line Cinema 1992), Alec Baldwin plays the manager of a group of real estate salesmen. He tries to pressure his all-male salesfonce into high performance by setung up a competition in which the top performer wins a Cadillac while the lowest performer is fired. Although such a competition is not inherently gender-based, the manager uses deeply gendered language that links sales capability to an aggressive masculinity. The manager describes top performers as real men. stalung. "Do you know what it takes to sell real estate? It takes brass balls to seil real estate." Id. In contrast, the manager berates low performers as "fucking faggots" who "can'I play the man's game." Id. Jack Lemmon plays an older man whose sales performance has been slipping. Desperate to close a sale so he can finance needed medical care for his daughter, he has lost his former status as the possessor of masculine sales prowess, which a younger salesman played by A! Pacino now holds. Advancing age is thus depicted as a sign of declining masculine competence.

Managerial status is also associated with lacking the wits and initiatuve needed to make it as a salesperson. When the manager inadvertently disrupts a deal that the salesman played by Al Pacino is attempting to close through fraudulent means, the Pacino character tums the manager's use of gender-based epithets against his boss by emphasizing that he is not man enough to succeed at sales:

You stupid fucking cunt.... You just cost me six thousand dollars, and one Cadillac..

Anyone in this office lives on their wits. What you're hured for is to help us-does that seem

clear to you? To help us. Not to fuck us up . . . To help men who are going out there to try Id.

to earn a living, you fairy.

472. For analyses of occupations in which male workers have characlenzod the content of what it takes to do a good job with qualities they appropriated as masculine, see CYNTHIA COCKBURN. MaChINERY OF DOMINANCE: WOMEN, MEN, AND TECHNICAL. KNOW-HOW 171-76 (Northwestem Univ. Press 1988) (1985). which discusses how male engineers see themselves as having a natural aptutude for technological work that they characterize as naturally masculine; ROBERT CONNEL, GENDER AND POWER: SOCIETY. THE PERSON AND SEXUAL POLITICS 180 (1987), which describes how male workers in blue-collar jobs define their competence in terms of physical prowess and express sexual contempt for men in managenal or office positions; and JENNIFER L. PIERCE, Gender TRIALS: EMOTIONAL LIVES IN CONTEMPORARY LAW FIRMS 50-82 (1995), which analyzes how male trial lawyers characterize themselves as "Rambo Litigators" who excel through a hyper-aggressiveness that they define in musculıne terms.

473. See, e.g., Sanchez v. Miami Beach, 720 F. Supp. 974, 977 n.9 (S.D. Fla. 1989) (discussing a female police officer who was subjected to graffiti suggesting she was a lesbian and had male genitalia); Berkman, 580 F. Supp. at 231 (discussing a female firefighter who was subjected to "crude graffitı questioning her sexual preferences"); see also Benecke \& Dodge, supra note 400; Pollack. supra note 447. at $78 \mathrm{n.178}$, and cases cited therein.

474. See Baron, supra note 398 (documenting how male printers were threatened by the admission of boys to apprenticeships); see also Doe v. City of Belleville. 119 F.3d 563. 566-67 (7th Cir. 1997) (involving two male plaintiffs, 16-year-old twin brothers. who were hired to Hork for the summer as landscapers and who were harassed by their adult male coworkers). 
send a man" ceases to have meaning if there is no difference in capability between the men and the boys. In a similar way, the work-gender link can be disrupted by the presence of other males who fail to conform to the definition of masculine mastery that the dominant group has projected onto the work (to be reflected back onto themselves). The desired masculine persona varies with the type of work involved: Professional boxers, no doubt, see the manly qualities of their calling differently from research scientists, for example. Contradictions abound: Whereas some male workers define the masculine character of their work in terms of a capacity for "hard" physical labor, others see masculine competence in the performance of mental or intellectual activity that other men would see as "soft."475 In other occupations, the desired image of masculine mastery is defined in terms of a conventional, head-of-the-household status, which is seen as befitting a member of the trade. Thus, in many male-dominated work settings, the dominant group is not only threatened by the presence of any man perceived to be homosexual-for homosexuality is viewed as an expression of gender deviance-but the group may also be threatened by the presence of men who are not married, men who have trouble with women, men whose wives or girlfriends earn more money than they do, men who perform significant childcare or housework, men who are "overly" emotional, men who are openly supportive of women's causes-or any other men whom the dominant group believes convey an image of masculine weakness or gender nonconformity.

Just as dominant male workers may harass women who threaten their idealized image of masculinity on the job, they may also harass such nonconforming men. This form of harassment, like harassment of women workers, perpetuates job segregation by sex. As we have seen, one important way in which male workers reproduce such segregation is by perpetuating the belief that only those who possess certain idealized masculine qualities are competent to perform traditionally segregated jobs. We have seen how men can sustain this impression by harassing women workers. They can also sustain it by engaging in harassment that drives away men who fail to conform to the desired image of masculinity or that incorporates them as weak and inferior workers.

Because many heterosexual men regard any failure to conform to their own preconceived notion of masculinity as a sign of homosexuality-and homosexuality as a failure to conform to their preconceived notion of

475. Masculinity is, of course, not monolithic. Sometimes, the contradictions within a group of male workers' images of themselves are exposed as the men's careers unfold. When they do hands-on machine work early in their careers, for example, male engineers tend to defend the masculinity of their jobs in terms of a hard-soft dichotomy that defines "hard," physical work as masculine and "soft," intellectual work as feminine. In middle age, however, many of these same men move on to managerial desk jobs that they once denigrated as unmanly. See CocKBURN, supra note 472, at 195. These men then adopt an intellectualnonintellectual dichotomy that, ironically, associates masculinity with the intellectual and femininity with the physical. See id. at 195-97. 
masculinity-such harassment frequently includes antigay sentiments. Indeed, sexual orientation and gender are often linked symbolically around the issue of work competence. Just as many women are labeled lesbians simply because their proclivity for male-dominated work threatens the projected masculine competence of the men who do that work, so too men whose actions or personae jeopardize that competence may be presumed to be or taunted as gay. Simply because hostile work environment harassment may include some antigay expression, however, does not mean that it is not based on gender. Regardless of whether the harassee's sexuality is placed at issue, such harassment is gender-based if it denigrates the harassee's manhood or otherwise prescribes how the harassee should be or should behave on the job. As the Supreme Court's decision in Price Waterhouse v. Hopkins ${ }^{476}$ instructs, imposing pressure to conform to preconceived notions of appropriate manhood or womanhood at work is the essence of differential treatment "because of sex" within the meaning of Title VII. ${ }^{47}$

The lower courts, however, have not viewed male-on-male harassment from this perspective. Instead, they have analyzed these cases from the vantage point of the sexual desire-dominance paradigm. Within that framework, the gendered character of male-on-male harassment remains imperceptible because it does not conform to the contemplated male-female, dominant-subordinate configuration. Several cases illustrate this problem.

In Goluszek v. Smith, ${ }^{478}$ the plaintiff was an electronic maintenance mechanic who worked in a plant that treated paper with polyethylene coating for freezer wrap and the like. His job was to maintain and repair the machines used in production. Goluszek lived with his mother and had never married. There was no evidence that he had homosexual inclinations. An expert testified that he came from an "unsophisticated background" and had led an "isolated existence" with "little or no sexual experience." ${ }^{\mathrm{N79}} \mathrm{He}$ "blushe[d] easily" at the mention of sexual matters. ${ }^{480}$

Almost as soon as Goluszek began work, a group of machinists began to harass him. They did not accuse him of being gay, but acted on gender-based expectations to assault his masculinity, for he did not fit their image of the type of man who should be a mechanic and member of the Teamster's union. They taunted him about not having a wife or girlfriend, telling him a man had to be married to work in the plant. They told him he should get married and should go out with a female coworker named Carla Drucker, because she "fucks." 481 They used other gender-stereotyped images to assault his work

476. 490 U.S. 228 (1989), discussed supra text accompanying notes 287.289.

477. See id. at 251 .

478. 697 F. Supp. 1452 (N.D. Ill. 1988).

479. Id. at 1453 .

480. Id.

481. Id. 
competence, telling him that if he could not fix a machine, they would send in his "daddy"- the supervisor-to do it. They made other comments that linked their assaults on his work competence to attacks on his sexual virility. They told him that if he could not fix a machine, they would get "Carla Drucker to fix" him. ${ }^{482}$ Eventually, Goluszek's coworkers resorted to work sabotage in an attempt to drive him out of his job. They drove jeeps at him and threatened to knock him off his ladder. When he filed a grievance, his supervisor punished him instead of his coworkers by writing him up for alleged carelessness in his work. Subsequently, he was transferred to a different shift where the machinists accused him of being gay or bisexual and made crude sexual overtures. ${ }^{483}$ Goluszek continued to be taunted and to receive warnings about his performance. Eventually, he was fired.

In an analysis that illustrates the logic of the sexual desire-dominance paradigm, the court granted summary judgment against the plaintiff on his hostile work environment claim. The court acknowledged that "Goluszek may have been harassed 'because' he is a male" 484 - the very definition of sex-based conduct that violates Title VII. Nonetheless, the court concluded that Goluszek had not stated an actionable claim: "Title VII does not make all forms of harassment actionable, nor does it even make all forms of verbal harassment with sexual overtones actionable." ${ }^{, 45}$ In a classic statement of the sexual desire-dominance model, the court pronounced: "The 'sexual harassment' that is actionable under Title VII 'is the exploitation of a powerful position to impose sexual demands or pressures on an unwilling but less powerful person.' Actionable sexual-harassment fosters a sense of degradation in the victim by attacking their sexuality." ${ }^{, 486}$

The court emphasized that the harasser-harassee configuration did not fit the typical male-female pattern: "Goluszek was a male in a male-dominated environment .... [E]ach and every one of [his harassers] was a male." According to the court, these facts alone proved that the harassment could not be "anti-male." ${ }^{\text {" } 488}$ At least in the absence of evidence that the harassers desired sexual relations with Goluszek, the court could not conceive how harassment of a male coworker might violate Title VII. The fact that an incumbent group of male workers might oppress a man because he failed to

482. Id.

483. This group of machinists "asked [Goluszek] if he had gotten any 'pussy' or had oral sex, showed him pictures of nude women, told him they would get him 'fucked,' accused him of being gay or bisexual, and made other sex-related comments. The operators also poked him in the buttocks with a stick." fd. at 1454. Goluszek also complained that he was being harassed by employees "out there talking to me about butt fucking in the ass." Id.

484. Id. at 1456 .

485. Id.

486. Id. (quoting Note, Sexual Harassment Claims of Abusive Work Environment Under Title VII, 97

HARV. L. REV. 1449, 1451-52 (1984)) (citations omitted).

487. Id.

488. Id. 
satisfy their image of the married, sexually robust tradesman was lost on the court. Viewed through the lens of the sexual desire-dominance paradigm, masculinity is monolithic and workplace harassment always comes in the form of sexual exploitation.

Martin v. Norfolk Southern Railway Co ${ }^{489}$ provides a second illustration. Edwin Martin was a mechanical supervisor in a diesel shop at a railroad yard. His immediate supervisor, a fellow mechanical supervisor, and one of his subordinates subjected him to a pattern of sexual overtures and taunts sufficiently extreme that the court concluded they stated a claim for the tort of outrage. ${ }^{490}$ Although the harassment was sexual in content, the court concluded that it was not motivated by a desire for actual sexual relations. Instead, the harassment functioned to impugn Martin's manliness. Some of the harassment insulted Martin's girlfriend (who soon became his wife): The harassers called her "ugly," "made improper and inappropriate remarks" about her, and asked Martin where he was getting sex. ${ }^{491}$ Other incidents took on the flavor of gay-bashing: The men told Martin he looked like he had AIDS and called him and two other employees the "Three Muskequeers." majority of the incidents were ambiguous; they could be interpreted as marking Martin with homosexual affinities or as accusing him of "feminine" attractiveness (or both). His harassers called him "pretty" and "cute," fashioned a piece of computer paper around his head as a scarf, and told him they would like to "bend him over a chair and have sex with him." ${ }^{\text {"93 }}$ They also offered to show him their penises and asked to see his; grabbed at his legs, rear end, and genitals; placed him in a headlock, pinched him, and tried to kiss him. ${ }^{\text {sh }}$ Regardless of the precise form of the harassment, however, it was clear that all the attacks were gender-based: Whether they were reducible to gay-bashing or were a reaction to Martin's perceived gender-nonconformity (or both), the content and the context of the incidents suggested that Martin's harassers meant to malign his masculinity by implying that it was different-and inferior-to their own. ${ }^{495}$

The court's analysis began auspiciously. The court observed that, "[u]nder the plain language of the statute, employment discrimination based on gender

489. 926 F. Supp. 1044 (N.D. Ala. 1996).

490. See id. at 1052 (concluding that the conduct at issue was sufficient to survive a motion for summary judgment on the tort of outrage, where the ton was reserved for "..conduct so outrageous in character and so extreme in degree as to go beyond all possible bounds of docency. and to be regarded as atrocious and utterly intolerable in a civilized society" (quoting American Road Serv. v. Inmon. 394 So. 2d 361, 365 (Ala. 1980))).

491. Id. at 1046-47.

492. Id. at 1047.

493. Id.

494. See id.

495. In blue-collar occupations, male workers frequently define their manly competence in terms of a virile physical prowess and express sexual contempt for men they perceive as weat and unmanly. See CONNELL, supra note 472, at 180. 
is prohibited,"496 and concluded that even "same-gender discrimination . . . is within the statute's reach provided the discrimination occurs because of the employee's gender." "497 Immediately after announcing these principles, however, the court undermined them. Based on its application of the twin strands of the definition of harassment in the prevailing paradigm-sexual desire and sexual dominance-the court proclaimed that Martin's hostile work environment claim was not actionable as discrimination. ${ }^{498}$

First, to support the sexual dominance theory, the court cited Goluszek for the proposition that sexual harassment is actionable under Title VII as sex discrimination only where it involves "'the exploitation of a powerful position to impose sexual demands or pressures on an unwilling but less powerful person." "499 Extending Goluszek to its logical conclusion, the court stated: "This [sexual exploitation] theory focuses on whether there is an atmosphere of oppression by a 'dominant gender,' and thus assumes that the harasser and victim must be of opposing genders." ${ }^{, 500}$ Second, the court made clear that it is the presence of sexual desire that supplies the inference of gender domination or discrimination where the harasser and victim are of the "opposing genders" and the male is superior and the female subordinate. Drawing on the reasoning of early quid pro quo cases such as Barnes $v$. Costle ${ }^{501}$ the court noted that the presumption of sexual desire applies not only to advances made by heterosexual men on women, but also to advances made by homosexual men on other men (and, in a novel twist, to advances made by bisexual men on other men):

In a situation where a male sexually harasses a female, there is the presumption that he does so because she is a female and that he would not do the same to a male. The same is true when a homosexual or bisexual male harasses another male; there is the presumption that the harasser does so because he is sexually attracted to the male victim and would not treat a female in the same manner. The presumption arises from the sexually oriented harassing conduct and is predicated on the perceived need for sexual gratification. Because of the demand by the harasser for sexual gratification, the victim is singled out because of his or her gender. ${ }^{52}$

496. Martin, 926 F. Supp. at 1048 (citing Hopkins v. Baltimore Gas \& Elec. Co., 871 F. Supp. 822, 833 n.17 (D. Md. 1994)).

497. Id. (quoting Tietgen v. Brown's Westminister Motors, Inc., 921 F. Supp. 1495, 1500 (E.D. Va. 1996)).

498. See id. at 1050 .

499. Id. at 1049 (quoting Goluszek v. Smith, 697 F. Supp. 1452, 1456 (N.D. Ill. 1988)).

500. Id.

501. 561 F.2d 983 (D.C. Cir. 1977), discussed supra text accompanying notes 89-93.

502. Martin, 926 F. Supp. at 1049. The court's casual extension of the Barnes reasoning to cover a bisexual man's advances on another man is puzzling. As the passage quoted reveals, the Martin court followed the Barnes court in reasoning that a heterosexual male supervisor's advances toward a woman are based on sex because they are grounded in a sexual attraction that the supervisor would not feel for a man; similarly, a homosexual male supervisor's advances toward a man are based on sex because they are 
Based on this reasoning, the court concluded in a final passage that heterosexual male-on-male (or female-on-female) harassment could never occur "because of sex" within the meaning of Title VII:

[I]n the case of same-sex heterosexual hostile working environment sexual harassment, the presumption of sexual gratification and thus, sex discrimination, ceases to exist . . . . Therefore, the court holds that same-sex heterosexual hostile working environment sexual harassment is not actionable under Title VII. ${ }^{503}$

In the court's analysis, gender discrimination is compressed to sexual desire. There is no room for an account of male workers' harassment of other men that recognizes that sexuality can be a potent weapon, without reducing the entire gender-based struggle over the definition of dominant masculinity to a desire for sexual gratification. This analysis has an ironic implication: In cases of male-on-male harassment, even participation in explicitly sexual advances does not signify the presence of the desire that damns men who harass women. Men who make sexual overtures toward other men are presumed to be solidly heterosexual, absent proof to the contrary. ${ }^{504}$

In McWilliams v. Fairfax County Board of Supervisors, ${ }^{\text {sos }}$ the Fourth Circuit adopted these propositions expressly. Mark McWilliams was an auto mechanic for a state agency who had a learning disability that had "arrested his cognitive and emotional development." 506 His coworkers-known colloquially as the "lube boys"-subjected him to a host of harassment, which expressed contempt for what they perceived as his failed masculinity. The men

grounded in a sexual attraction that the supervisor would not feel for a woman. See td:; see also Bames. 561 F.2d at $989 \&$ n.49. On first reflection, such reasoning would not cover advances made by a bisexual supervisor because the supervisor would experience sexual altraction for. and thus might direct sexual advances toward, both men and women. See Barnes. 561 F.2d at 989 n.49. Of course, even under a desire-based paradigm, courts might avoid such a result by appealing to an arguably more nuanced concept of causation in which a bisexual supervisor's advances would be based on sex because the supervisor would experience sexual attraction for both men and women in gendered terms (that is, the supervisor would be attracted to men as men, and to women as women). It seems unlikely that the Mfartin court had such an analysis in mind, in light of the casual and unanalyzed nature of the court's reference to bisexual advances: more likely, the court simply unthinkingly included such advances as close cousins of homosexual advances, even though the inclusion of bisexuality rendered the court's own reasoning incoherent.

503. Martin, 926 F. Supp. at 1049.

504. Ultimately, such logic is tautological: In cases involving male-on-female sexual advances, courts presume from the content of the harassment that the harasser is heterosexual and hence acted from the sexual desire that, in turn, supplies the presumption that the advance would not have been made toward a man. Yet, in cases involving male-on-male harassment, courts are not willıng to infer from stmilar conduct a parallel presumption that the harasser (who may self-ıdentify as heterosexual) has any homosexual inclinations. Instead, men who make crude sexual overtures toward other men are assumed to be solidly heterosexual. See, e.g., McWilliams v. Fairfax County Bd. of Supervisors, 72 F.3d 1191, 1195 n.5 (4th Cir. 1996) (noting that in same-sex harassment claims. homosexuality may not be presumed from actions, but must be proven). Thus, male-female pairings are deemed sex-based because they are presumed to be driven by sexual desire while male-male (or female-female) parings are denied that status because they are presumed to be driven by considerations other than sexual desire.

505. 72 F.3d 1191 (4th Cir. 1996).

506. Id. at 1193. 
taunted him with such remarks as, "The only woman you could get is deaf, dumb, and blind." 507 They teased him about his sexual activities, exposed themselves to him, and sexually assaulted him by forcing a finger in his mouth to simulate oral sex and placing a broomstick to his anus while exposing their genitals. Despite the sexually explicit nature of these overtures, the court characterized the conduct as "heterosexual" and concluded, like the Martin court, that such "heterosexual-male-on-heterosexual-male conduct" is not "because of the [target's] 'sex." men were not heterosexual and a different conclusion on causation were required, "the fact of homosexuality (to include bisexuality) should be considered an essential element of the claim, to be alleged and proved."\$09 Otherwise, feared the court, Title VII might be construed to cover "conduct merely suggestive of homosexuality between persons of the same sex who actually are heterosexuals." 510 Even the dissent adopted a desire-centered paradigm. ${ }^{511}$ As with the Goluszek and Martin courts, it occurred to neither the majority nor the dissenting judges that the sexual content of McWilliams's coworkers' conduct might be only a tool to accomplish a larger project: that of emasculating-and expelling-a mechanic so beset with gender affliction as to be unfit to be a "lube boy."

In Dillon v. Frank, ${ }^{512}$ the Sixth Circuit squarely confronted such a gender-based argument. Ernest Dillon was a postal worker who was tormented by his coworkers. One fellow employee called Dillon a "fag," pushed materials into Dillon's work area, turned off the bathroom lights when Dillon entered, and physically assaulted Dillon so seriously that he suffered numerous injuries. Other employees followed suit: They subjected Dillon to a "full orchestral assault" of antigay epithets and such publicly displayed graffiti such as "Dillon sucks dicks" and "Dillon gives head." 513 Although the Postal Service fired the man who assaulted Dillon, it did little or nothing to curb the harassment

507. Id.

508. Id. at 1195-96.

509. Id. at 1195 n.5.

510. Id. For critiques suggesting that in many cases it might be difficult to determine whether people actually are heterosexuals or homosexuals in any fixed sense, see EVE K. SEDGWICK, EPISTEMOLOGY OF THE CLOSET 22-27 (1990); Janet E. Halley, The Politics of the Closet: Towards Equal Protection for Gay. Lesbian and Bisexual Identity, 36 UCLA L. REV. 915, 933-63 (1989); and Kenneth L. Karst, Myths of Identity: Individual and Group Portraits of Race and Sexual Orientation, 43 UCLA L. REV. 263, 274-89 (1995).

511. See McWilliams, 72 F.3d at 1198 (Michael, J., dissenting). As Judge Michael wrote:

I believe the majority makes a mistake to affirm summary judgment on the ground that there is no allegation that McWilliams and his male harassers are of different sexual orientations. ... I would simply hold that Title VII is implicated whenever a person physically abuses a co-worker for sexual satisfaction or propositions or pressures a co-worker out of sexual interest or desire. This can be established by an account of what the harasser did or said to the Id. victim, and proof of the harasser's sexual orientation should not be required.

512. No. 90-2290, 1992 U.S. App. LEXIS 766 (6th Cir. Jan. 15, 1992).

513. Id. at $* 2-3$. 
by his other coworkers. His employers "threw up their hands in despair, telling Dillon not to waste their time with his complaints and to fight back when taunted." ${ }^{.14}$ After enduring abuse for three years, Dillon eventually resigned upon advice from his therapist.

Dillon alleged that his coworkers tormented him because he failed to conform to their expectations of suitable masculinity. In his view, his coworkers' antigay ridicule was in the service of sexism: "He contended that he was subjected to [sex] stereotyping in that he was not deemed 'macho' enough by his co-workers for a man" and that the "abuse relating to [his perceived] homosexuality [occurred] solely because he was a man," in violation of Title VII. ${ }^{515} \mathrm{He}$ argued that the Supreme Court's decision in Price Waterhouse v. Hopkins ${ }^{516}$ supported this theory: Just as Title VII prohibits an accounting firm from requiring a female partnership candidate to conform to its gender-based expectations for appropriately feminine behavior, the statute also prohibits an employer from permitting its employees to create a hostile work environment for a male worker based on his failure to conform to its gender-based expectations for a fitting masculine image. ${ }^{517}$

Despite the simplicity of such reasoning, the Sixth Circuit rejected it on two related grounds. First, the court inverted Dillon's argument in order to reject it. According to the court, the fact that the content of the harassment directed at Dillon was sexual was irrelevant-a hostile work environment plaintiff must prove that the harassment was based on sex. Here, "Dillon's co-workers deprived him of a proper work environment," not because of his sex, but instead "because they believed him to be homosexual." 118 Yet, discrimination on the basis of homosexuality does not violate Title VII, the court concluded, and thus Dillon failed to state an actionable claim. ${ }^{319}$

The court's analysis was beside the point, however, in light of what Dillon had actually argued. Contrary to the court's characterization, Dillon had not argued that the sexual content of the harassment or the fact that he was picked on for his perceived homosexuality made the conduct illegal; to Dillon, those facts were subsidiary. He had argued, instead, that the harassment was illegal because it was based on his sex. That it consisted of crude forms of gay-bashing was relevant only as evidence that his harassers had subjected him to gender stereotyping; in their eyes, his alleged homosexuality made him a lesser man not suitable to stand alongside them as a postal worker.

In a second passage, the Sixth Circuit purported to confront Dillon's actual argument, but continued to misconstrue it: "Dillon attempts to avoid [the fact

514. Id. at *3.

515. Id. at $* 15$.

516. 490 U.S. 228 (1989),

517. See Dillon, 1992 U.S. App. LEXIS 766, at $* 15$.

518. Id. at $* 22$.

519. See id. at *22-23. 
that discrimination on the basis of homosexuality is not proscribed] by alleging that he was discriminated against because he was male." ${ }^{\text {220 }}$ The court rejected this argument on the ground that Dillon had "not shown that his co-workers would have treated a similarly situated woman any differently." 521 His inability to make such a showing, however, was based on the fact that the court once again converted his argument about gender stereotyping into one focused on sexuality. According to the court, Dillon's argument that he was treated differently because of his sex "must presume that the abuse was directed at his supposed homosexuality or at specific sexual practices (such as anal sex or fellatio)." ${ }^{1522}$ In other words, Dillon had to show that a woman who was perceived to be a lesbian or to engage in oral sex with men would not have been subjected to harassment. Once the court forced Dillon into such a comparison, the court's ruling became a foregone conclusion: "[Dillon] has not argued that a lesbian would have been accepted at the Center, nor has he argued that a woman known to engage in the disfavored sexual practices would have escaped abuse," concluded the court. "Without such a showing, his claim to have been discriminated against because he is male cannot succeed." 523

But this was not Dillon's argument. Dillon's analogy to Price Waterhouse had been perfectly clear: Just as the female partnership candidate in that case was treated differently based on her sex-in the sense that a male candidate would not have been counseled to behave more femininely-so, too, Dillon claimed that he was treated differently based on his sex, in the sense that a female postal worker would not have been censured for failing to behave in a more suitably masculine manner. The court's choice not to use Dillon's framing of the male-female comparison was not mere semantics. As others have pointed out, the results of a disparate treatment analysis can turn on the way the comparison is framed; ${ }^{524}$ the choice of framework invariably conveys something important about the way a court comprehends the problem.

The Sixth Circuit was wrong in stating that it was Dillon who was trying to avoid the problem posed by his alleged homosexuality by framing the harassment as gender discrimination. Rather, it was the court that sought to avoid the truth of Dillon's contention that his male coworkers had discriminated against him based on his perceived gender nonconformity. It did so by renaming the harassment sexual orientation discrimination. In so doing, the court set up a standard of two-tiered justice. True, it had initially declared

520. Id. at $* 26$.

521. Id.

522. Id.

523. Id. at $* 27$.

524. See, e.g., General Elec. Co. v. Gilbert, 429 U.S. 125, $147-48$ (1976) (Brennan, J., dissenting) (arguing that the resolution of an equal protection case "turns largely upon the conceptual framework chosen" for comparison). 
that the relevant hostile work environment inquiry turned on the motivation or meaning underlying the harassment rather than the form or content of its expression. But it then reframed the problem to permit the harassment to evade substantive review merely because it included some antigay content. Yet, there is no reason that harassers who engage in impermissible gender stereotyping should be able to insulate themselves (and their employers) from Tite VII liability merely by including among their hostile expressions charges of homosexuality or antigay sentiments.

This point may be illustrated by a hypothetical change in the facts of Price Waterhouse. Imagine that Ann Hopkins had not only been counseled to "walk more femininely, talk more femininely, dress more femininely, [and] wear make-up," 225 but also had been cautioned "not to be such a dyke." Surely, the mere addition of this suggestion would not have changed the Supreme Court's conclusion that the firm had engaged in impermissible gender stereotyping. To allow such a result would permit the courts to deny Title VII's protection to victims of sex discrimination simply because their harassers regard or taunt them as homosexuals or because the victims have identified themselves as such. This is tantamount to excluding people identified as gay from the protection from gender stereotyping extended to all other people as men and women. By denying Dillon the protection from gender stereotyping he was due under Price Waterhouse, the Sixth Circuit effected precisely such an exclusion.

There is another sense in which the Sixth Circuit's decision in Dillon contributes to a two-tiered application of Title VII. Under the reasoning of Barnes v. Costle, Martin, and McWilliams, a homosexual man who makes sexual advances toward another man is responsible for the harassment. Such harassment occurs "because of sex" because it is presumed that someone with homosexual inclinations would not direct similar attentions toward a person of the opposite sex. Under Dillon, however, heterosexual men who direct sex-based harassment toward other men whom they accuse of being homosexual will get off scott-free. Worse yet, McWilliams suggests that men who direct forms of harassment other than explicit sexual propositions toward other men will be presumed to be heterosexual, unless actually proven to be otherwise. ${ }^{526}$ Taken together, the cases create a biased form of justice: Men who are perceived to be homosexuals are excluded from protection against sex-based harassment, but men who engage in antigay harassment of other men will be presumed to be heterosexual and will not be held responsible. Indeed, some courts have expressly embraced such logic. ${ }^{527}$

525. Price Waterhouse v. Hopkins, 490 U.S. 228, 235 (1989).

526. See McWilliams v. Fairfax County Bd. of Supervisors, 72 F.3d 1191. 1195 n.5 (4th Cir. 1996); see also supra note 504.

527. See, e.g., Wrightson v. Pizza Hut of Am., Inc., 99 F.3d 138. 143 (4th Cir. 1996) (")[W]c hold that a same-sex 'hostile work environment' sexual harassment claim may lic under Title VIl where a 
There is nothing in the language or purpose of the statute, however, that requires such a biased pattern of protection and responsibility. But for the blinders of the prevailing paradigm, the courts would not have created such a pattern. In reality, male-on-male harassment may have little to do with sexual desire or practices. ${ }^{528}$ Male workers often resort to sexually explicit taunts and assaults and make accusations of or derogate a harassee's homosexuality along with other forms of harassment that make no overt reference to sexuality but operate to insult the harassee's manhood-as a form of branding men who fail to satisfy their image of suitable masculine mastery for the job as different and inferior.

Thus, accusations of and antagonism toward homosexuality are relevant, but not because such actions signal anything about whether sexual desire is present between harassers and harassees. They are relevant because antigay harassment frequently evidences gender stereotyping. ${ }^{529}$ The allegation that a man is gay is often an accusation that he does not live up to one's expectations of masculine competence. Because the harassers' remarks about sexual orientation provide clearer evidence of their purpose, proof of the harassee's actual sexual orientation should not be required. It is the accusation rather than the actuality that is relevant. Nor is evidence of the harassers' sexual orientation relevant. The existence of sexual desire between harassers and harassees should not be part of the inquiry; men of any sexual orientation should be presumed capable of impermissible gender stereotyping of other men (or women).

Indeed, courts should recognize that gender-based denigration of competence may occur across various configurations of the sexes. ${ }^{530}$ Just as

homosexual male (or female) employer discriminates against an employee of the same sex or permits such discrimination against an employee by homosexual employees of the same sex.").

528. Cf. Zalewski v. Overlook Hosp., 692 A.2d 131, 133-34 (N.J. Super. Ct. 1996) (recognizing a cause of action for same-sex hostile work environment harassment regardless of the content of the harassment and regardless of the sexual orientation of the harassers). As the Zalewski court wrote:

It is being the victim of anti-male or anti-female bias that forms the basis of a Title VII sexual harassment claim, not simply being exposed to 'sexual'-type comments or behavior. Title VII is meant to rectify gender bias in the workplace, not per se to outlaw foul mouths or obscenities. Sometimes sexually-explicit comments are evidence of or constitute gender bias, and sometimes not. Id. at 134 .

In Doe v. City of Belleville, 119 F.3d 563 (7th Cir. 1997), the Seventh Circuit recognized that same-sex harassment, like harassment directed at the opposite sex, need not be explicitly sexual in content to be based on sex within the meaning of Title VII. See id. at 581 (relying on Price Waterhouse v. Hopkins, 490 U.S. 228 (1989), to conclude that "a man who is harassed because his voice is soft, his physique is slight, his hair is long, or because in some other respect he exhibits his masculinity in a way that does not meet his coworkers' idea of how men are to appear and behave, is harassed 'because of' his sex").

529. For discussions of how bias against gay men and lesbians may evidence an underiying anxiety that homosexuality subverts traditional gender roles, see Marc A. Fajer, Can Two Real Men Eat Quiche Together?, 46 U. MIAMI L. REV. 511 (1992); Kenneth L. Karst, The Pursuit of Manhood and the Desegregation of the Armed Forces, 38 UCLA L. REV. 499 (1991); and Sylvia Law, Homosexuality and Social Meaning of Gender, 1988 WIS. L. REV. 187, 187.

530. Cf. Baskerville v. Culligan Int'l Co., 50 F.3d 428, 430 (7th Cir. 1995) (observing that "Is]exual harassment of women by men is the most common kind, but we do not mean to exclude the possibility that 
some men may bash other men as gay in order to denigrate their masculinity, men may also bait women as lesbian to demarcate them as gender deviants. For purposes of hostile work environment analysis, both forms of antigay ridicule are analogous to the forms of harassment directed at women workers who cross the gender divide into male-dominated terrain.

Although this analysis recognizes that same-sex, gender-based hostile work environment harassment may include antigay conduct, it does not conflate harassment on the basis of gender with harassment on the basis of sexual orientation. ${ }^{531}$ Consequently, courts should not be concerned that adopting this approach would merely accomplish indirectly a prohibition against sexual orientation discrimination that Congress has, so far, declined to do directly. ${ }^{532}$ The competence-centered approach contemplates that men of any sexual orientation may seek to endow their work with an idealized masculine image by denigrating women or men of any sexual orientation who detract from the desired image. Just as the approach does not reduce all gender-based, same-sex harassment to sexual orientation discrimination, neither does it treat all sexualorientation-based classifications as gender-based discrimination. Some discussions and overtures-and perhaps even some forms of outright discrimination based on sexual orientation-are not gender-based attempts at denigration and would not be actionable under this approach. ${ }^{533}$

Contrary to the reasoning expressed in Dillon, however, the fact that a group of male workers might direct harassment of a similar form or content toward both male and female workers does not mean that the harassment is not gender-based. To the contrary, once a sexual desire model is abandoned, the fact that the men who harass seek to police their occupational boundaries against both women and nonconforming men might be evidence that the harassment of each group is based on gender. What matters is not whether the men direct even the very same taunts toward men and women ("Dillon sucks

sexual harassment of men by women, or men by other men, or women by other wornen would not also be actionable in appropriate cases").

531. Recent work on sexual orientation recognizes that antigay discrimunation has some of its own unique dynamics that are not reducible to gender bias. See. e.g. SEDGWICK. supro note 510. at 31 (speculating that gender-based analyses may have an implicit heterosexual bias that can only be corrected by studying the unique dynamics of homosexuality beyond gender); Janel E. Halley, Reasoning About Sodomy: Act and Identity In and Afier Bowers v. Hardwick. 79 VA. L. REV. 1721. 1724 (1993) ("Though they intersect, gender and sexuality exceed and differ from one another.").

532. See 142 CONG. REC. S10,129 (daily ed. Sepi. 10. 1996) (documentung the Senate's rejectuon by one vote of the Employment Nondiscrimination Act of 1996. S. 2056. 104th Cong. (1996)): see also Desantis v. Pacific Tel. \& Tel. Co., 608 F.2d 327, 329 (9th Cir. 1979) (noting that Congress had previously considered and rejected bills that would have prohibited employment discrimination based on sexual orientation).

533. One can imagine some forms of harassment or discrimunation of gay male workers that is rooted in a stereotypical and irrational fear of them as carriers of AIDS. for example. that would not necessarily be based on gender. As insidious as such discrimination might be, it would not be actionable under a competence-centered paradigm. In addition, one can imagine some conversations about homosexuality that would not be based on gender and would not be actionable under a competence-ceniered paradigm. For examples of such discussions, see infra text accompanying notes 5.2-5.43. 561 . 
dicks" and "Judy sucks dick");" 534 what matters is that, in both cases, the men's taunts seek to humiliate and alienate the harassed women and men because they fail to live up to their harassers' images of appropriate masculinity and femininity. Just as in male-on-female harassment cases, proof that a man went after women other than the plaintiff often confirms that the harassment of the plaintiff was based on sex, so too evidence that some male workers went after both women and men they perceived to be gender-deviant may confirm that the harassment of each group was based on gender-based notions of who should hold the job. Far from disproving the existence of discrimination based on sex, then, the fact that the harassers target women as well as men may tend to prove such discrimination.

This reasoning casts new light on cases like Lyman v. Nabil's, Inc., ${ }^{535}$ in which a court dismissed the claim of a male restaurant manager who complained that the owner subjected him to a hostile work environment by forcing him to observe and even to participate in the widespread harassment of female employees. According to the plaintiff Lyman,

[the owner] offensively touched and directed offensive language at women employees under Lyman's supervision. Lyman further allege[d] that the women complained to him about these offensive acts, that [the owner] made sexual comments about the women to Lyman, and that [the owner] made Lyman transfer the women from restaurant to restaurant in retaliation for their complaints . . . Lyman also allege[d] defendant . . . fir[ed] him for his complaining about the alleged discriminatory acts, his being supportive of women complaining of those acts, and his refusal to cooperate in defendant's retaliation against women. ${ }^{536}$

Operating under the prevailing paradigm, the court could not comprehend how the owner's sex-based harassment of women employees could constitute harassment of the male plaintiff. As a consequence, the court accepted the defendant's argument that "the conduct [the plaintiff] alleges was not offensive to [the plaintiff's] own gender"537 and dismissed the hostile work environment claim. Under a competence-centered account of harassment, however, a court would recognize that Lyman experienced a hostile work environment based on his own gender because the owner tried to force him to behave as, and eventually fired him for refusing to become, a manager who approves of and acquiesces in the harassment of women. Insofar as Lyman

534. Compare Dillon v. Frank, No. 90-2290, 1992 U.S. App. LEXIS 766, at *27 (6th Cir. Jan. 15, 1992), with Porta v. Rollins Envtl. Serv. (NJ), Inc., 654 F. Supp. 1275, 1279 (D.N.J. 1987) (describing "graffiti alleging 'Judy sucks Bernie's Dick"”), aff'd mem., 845 F.2d 1014 (3d Cir. 1988), quoted in Dillon, 1992 U.S. App. LEXIS 766, at *27.

535. 903 F. Supp. 1443 (D. Kan. 1995).

536. Id. at 1445 .

537. Id. at 1446. 
sympathized with and supported the cause of his female subordinates, he betrayed the type of dominant masculinity his supervisor expected of him as a manager. As a result, he was himself harassed and eventually fired. Although this misconduct was nonsexual in nature, it would be actionable under a competence-centered approach. ${ }^{538}$

As the analysis of these cases shows, the competence-centered paradigm would direct the courts' attention toward the processes through which men create work cultures that sustain their own idealized definitions of masculine mastery to the detriment of men who cannot or will not conform. The focus would no longer be on sexuality or sexual orientation. Whether harassment flows from men to women, men to men, women to men, or women to women, and whether it is sexual or nonsexual in content, the focus should not be on sexuality as such. The goal of harassment law should be to eradicate gender stratification, not to banish all sexual expression from the workplace. The next section elaborates on that theme.

\section{B. Reducing the Risk of Prohibiting Benign Sexual Expression}

Just as the sexual desire-dominance paradigm creates problems of underinclusiveness, it may also create problems of overinclusiveness by influencing courts and companies to characterize some benign forms of sexual expression as hostile work environment harassment. We have already seen how the sexual desire-dominance paradigm enables a paternalism that excludes many women who do not comport with the image of the proper victim in need of sexual protection. ${ }^{539}$ In addition, such paternalism risks encouraging courts and companies to overreach in an effort to protect women's sexual sensibilities from mere discussions of sexuality that do not threaten their equality in the workplace. Perhaps predictably, courts appear more likely to engage in such overreaching where the discussion involves sexuality perceived as deviant. ${ }^{50}$

538. Cf. Childress v. City of Richmond, 120 F.3d 476. 478 (4th Cir. 1997) (holding that white male police officers had standing to assert hostile work environment clams where they were subjected to adverse treatment after complaining that their precinct lieutenant's disparaging remarks against fernale and black officers created both a gender- and race-based hostile work environment that undermined "the necessary sense of 'teamwork' between officers of different sexes and races, and that this resultant loss of tcamwork raised the possibility that officers in one group might be reluctant to assist officers in another group dunng the performance of their duties on the streets"), rev'd en banc. 75 Farr Empl. Prac Cas. (BNA) (4th Cir 1998).

539. See supra Section II.D.

540. Cf. Carlin Meyer, Sex, Sin and Women's Liberation. 72 TEx L. REV. 1097, 1119-20 (1994) (noting that, in the context of pomography regulation. "UJudges, junes. and most members of the publıc are likely to find most explicit and 'deviant' sexual depictions repellant and view as degrading not only sexual portrayals that descriptively, humorously, playfully, or ironically depict subordinated women. but also those that are explicitly intended to challenge that subordınation"): Nadıne Strossen. A Femunist Critique of "The" Feminist Critique of Pomography, 79 VA. L. REV. 1099. 11.45-47 (1993) (stressing that censorship of pornography would likely be used against homosexuals, femsnusts. and those perceived to have deviant sexuality, and reporting allegations that Canadian customs censors have sıngled out gay and lesbian, as well as radical, bookstores). 
By reorienting the focus of harassment law toward conduct that promotes gender stratification, the new paradigm helps rectify this problem.

Contrary to the assumption of the sexual desire-dominance paradigm, gender inequality is not synonymous with sexual relations. ${ }^{541} \mathrm{Just}$ as gender-based oppression occurs outside the realm of the sexual, so too does the sphere of sexuality encompass more than simply oppression. Sexual relations (heterosexual or otherwise) do not inherently enact male dominance over women. Indeed, to characterize sexuality as such risks allowing heterosexual women to become the arbiters of others' sexual expression-including that of marginalized sexual minorities-even where that expression does not hinder women's full participation in the workplace. In Fair v. Guiding Eyes for the Blind, Inc. ${ }^{542}$ for example, a heterosexual woman who was the associate director of a nonprofit organization alleged that her gay male supervisor had created a hostile work environment by trying to draw her into conversations about homosexuality. Although the court correctly concluded that the supervisor's comments were neither gender-based nor actionable harassment, ${ }^{543}$ it is nonetheless disturbing that the governing legal paradigm encouraged a lawyer to bring such a case without risking sanction.

That Title VII law can be construed to characterize this kind of sex talk as actionable harassment may influence some companies to discipline or fire workers for sexual expression in an effort to avoid legal liability. Recently, for example, the Miller Brewing Company was assessed $\$ 26.6$ million in damages after it fired an executive, Jerold Mackenzie, whom a female employee, Patricia Best, had accused of sexual harassment. ${ }^{544}$ Mackenzie, who had worked for Miller for nineteen years, had commented to Best about an episode of Seinfeld that aired the night before. In the show, Seinfeld cannot recall the name of the woman he is dating. He knows that her name rhymes with a part of the female anatomy, however, and incorrectly guesses such names as "Mulva" and "Gipple." At the end of the show, as the woman breaks up with

541. This point is now widely recognized in feminist theory. Indeed, there is much feminist scholarship that criticizes earlier feminist thought for conflating gender inequality and (heterosexual) sexual relations. See, e.g., SCOTT, supra note 8, at 34 (criticizing feminist theoretical accounts of sexuality as the kcy to gender inequality for embracing circular logic in which "there is nothing except the inherent inequality of the sexual relation itself to explain why the [gendered] system of power operates as it does"); Dubois \& Gordon, supra note 46, at 32-39 (discussing how 19th-century social purity feminists' emphasis on sexuality as a realm of danger and oppression for women replicated sexist and classist tendencies within wider society to separate women into those deserving of protection and those deserving of condemnation); Franke, supra note 441 , at 759-62 (criticizing anti-subordination strands of 20th-century legal feminism for reducing the universe of sexism to sexual relations); Meyer, supra note 15, at $27-32$ (criticizing academic feminists for overemphasizing sexuality as a mechanism for reproducing gender inequality and discussing reasons that this group of feminists has focused on sexuality to the exclusion of other workplace issues important to women).

542. 742 F. Supp. 151 (S.D.N.Y. 1990).

543. See id. at $155-56$.

544. See James L. Graff, It Was a Joke! An Alleged Sexual Harasser Is Deemed the Real Victim, Time, July 28, 1997, at 62; see also Gretchen Schuldt, Former Miller Executive 'Shocked' by 'Seinfeld.' MiLWAUKEE J. SENTINEL, June 27, 1997, at 3. 
him, Seinfeld remembers her name and calls out, "Delores!" At work, Mackenzie recounted this episode to Best, and when she did not get the joke, he photocopied a dictionary page defining "clitoris" and handed it to her. Best complained to Miller officials that she was offended by Mackenzie's action, and they later fired him for "unacceptable managerial performance." "sis

The facts of the case, of course, bear more than one interpretation. It is possible that Mackenzie's conduct was less innocuous than it appears from the press accounts. Best testified, for example, that she was offended not merely by Mackenzie's handing her the dictionary page, but by the way he looked at her as he did so. Mackenzie had previously told her that he had dreamed about her and had left her a "romantic" voice-mail message. ${ }^{\text {s.6 }}$ After learning that Mackenzie dreamed only that Best was divorced, however, and after hearing Mackenzie's actual voice-mail message-in which Mackenzie refers to Best as a "breath of fresh air," but in a business context ${ }^{547}$-a twelve-person jury that included ten women decided that Mackenzie's conduct did not comport with their understanding of sex-based harassment. ${ }^{\text {sid }}$ Indeed, Miller may not have fired Mackenzie out of a genuine concern that his conduct left them vulnerable to liability for hostile work environment harassment, but may instead have used Best's accusation of harassment as a subterfuge for firing Mackenzie, whom they wanted to get rid of for other reasons. ${ }^{5+9}$

Regardless of the motivation behind Mackenzie's firing, the case has disquieting implications. At least on the facts recounted in the press, Mackenzie's conduct does not approach the son of gender-based hostility or denigration that threatened to undermine Best's - or other women's-equality in the workplace. Instead, Mackenzie appears to have been railroaded out of a company to which he devoted much of his life for having joked about a racy television episode and referred to female genitalia. Only a misplaced concern for women's sexual sensibilities accounts for Miller's action: Absent other indicia that Mackenzie's actions constituted or promoted gender inequality, the mere reference to sexual matters should not have been construed as harassing conduct that justified discharge. Indeed, feminists should be concerned about the prospect of companies firing men in Mackenzie's situation. For one thing, feminism receives a bad rap when workers are fired in the name of a feminist-

545. Graff, supra note 544 , at 62 .

546. Gretchen Schuldt, Ex-Miller Exec. Copied Page with Anatomical Word: Man Sung over Firng Says He Showed Copy to Female Co-Worker. MiLwAUKeE J. SENTINEL, June 26. 1997. at 1

547. Id.

548. See Dave Daley, Women Jurors Seen as Key ro Mackenzie's Court Victon: Mock Trals Showed That They Were More Sympathetic. MILWAUKEe J. SENTINEL. July 17. 1997, at 10: Fired Executive Awarded \$26.6 Million over 'Seinfeld' Rhyme, LEGAL INTELLIGENCER. July 17. 1997, al 4.

549. See Erik Brooks, 'Lighten Up' or 'Shut Up'?; Racy 'Seinfeld' Chat Not Harassment. Juny Rules: Women's Groups Angered, ChatTANOOGA TIMES, July 17. 1997, at A12: Dave Daley. S26 Million Awarded in 'Seinfeld' Case; Miller Firing Improper, Jur Decides. MilwaukeE J Sentivel. July 16. 1997, at 1 . 
inspired cause of action for merely talking about sex..$^{550}$ For another, such firings may sow the seeds of backlash against protecting women from genuinely harmful forms of hostile work environment harassment. ${ }^{551}$ Such seeds may become bitter weeds that choke legitimate causes of action if juries begin to assess damages against individual women who complain of harassment, as the jury did against Patricia Best. ${ }^{552}$

Other cases appear more difficult. In Pierce v. Commonwealth Life Insurance $\mathrm{Co}_{.}^{553}$ a male manager, Tom Pierce, was accused of sexual harassment after participating in an exchange of sexually explicit cards with a female office administrator, Debbie Kennedy. One of the cards Pierce sent read, "Sex is a misdemeanor. De more I miss, de meanor I get." was a cartoon valentine that read, "There are many ways to say 'I love you' . . but $\mathrm{f}$-ing is the fastest." ${ }^{\text {" } 55}$ According to Pierce and others in the office, Kennedy had also sent Pierce cards with sexually explicit messages and had engaged in other off-color behavior toward Pierce and other employees. ${ }^{55}$ In response to Kennedy's claim of sexual harassment, Pierce was disciplined. He was summarily demoted, with a significant reduction in pay, and transferred to another office on the ground that he had violated the company's sexual harassment policy. After spending thirty years with the company, Pierce was bid farewell by having "[his] personal belongings from the office ... dropped off to him at a 'Hardee's' roadside fast food restaurant." $" 557$

As with the situation involving Mackenzie, it is possible that the facts were less sympathetic to Pierce than they appear. Pierce was, after all, a manager, while Kennedy was not. Pierce was responsible for managing three offices and for enforcing the company's sexual harassment policy. The company claimed that he already had been counseled about two sexual harassment complaints in the past ten years-a record that Pierce denied. In light of his position of authority, Pierce's sending the two sexually explicit cards to Kennedy may suggest that his conduct veered perilously close to being actionable. Even if so, however, the reasoning that led the company to such a conclusion is unsound-and disturbing. The company relied on the sexually

550. In the media accounts I read, feminist concerns about the fact that companies might be using feminism as a justification for firing men on such grounds were missing. Indeed, at least one feminist group expressed the view that Mackenzie's conduct should have been punished. Deborah Lukovich, President of the Wisconsin NOW, was quoted as saying, "We're missing the message that that sort of discussion in the workplace is wrong." Brooks, supra note 549.

551. See Joanne Jacobs, Harassment Jury's Message: It's Time To Lighten Up, RECORD (Bergen, N.J.), July 24,1997 , at L9.

552. See Will Verdict Chill Harassment Complaints?, CAPITAL TIMES (Madison, Wis.), July 21, 1997. at $2 \mathrm{~A}$.

553. 40 F.3d 796 (6th Cir. 1994).

554. Pierce v. Commonwealth Life Ins. Co., 825 F. Supp. 783, 784 (E.D. Ky. 1993).

555. Id. at 799.

556. See id. at 779 \& n.2.

557. Id. at 800. 
explicit character of Pierce's actions, without ever examining whether such actions denigrated Kennedy's competence or otherwise disadvantaged her or other women in the office on the basis of their gender. ${ }^{558}$ In fact, in an amazing bit of reasoning that confiates all forms of sexual interaction, Pierce's superiors told him that he might as well have been a "murderer, rapist or child molester, that [what he did] wouldn't be any worse."

Such reasoning is dangerous. It invites companies to discipline or discharge workers for the wrong reasons. It is unclear how often companies rely on the threat of harassment suits to discipline workers for engaging in sexual expression, but some alarming stories have been reported. In one account, a male social worker was fired for imitating David Letterman and approaching a new female coworker with the comment, "I'm gonna flir with ya." 560 In another, a lesbian psychology professor's guest lecture on female masturbation prompted a sexual harassment lawsuit by a married, male Christian student, who claimed that he felt "raped and trapped" by the lecture. $^{561}$ In a third story, a male religion professor was formally reprimanded for "“engaging in verbal conduct of a sexual nature" that had the effect of "creating an intimidating, hostile or offensive environment" "S62 when he recited a story from the Talmud, the writings that make up Jewish law. The story involved a man who fell off a roof, accidentally landed on a woman, and had intercourse with her. The professor related that in the Talmud, the man is deemed innocent of sin because his act was unintentional. A female student in the class was offended by the story, and her sexual harassment complaint led the university to reprimand the professor and to record all his lectures with a tape recorder to ensure that he did not say anything sexually offensive in the future..$^{563}$

However subtly, the sexual desire-dominance paradigm enables (or even encourages) these kinds of complaints by emphasizing the "sexual" nature of harassment. These kinds of complaints tend to legitimate opposition to

558. See id. at 799. In fact, Kennedy's complaint against Pierce not only referred to the two sexually explicit cards, but also protested her most recent evaluation and denied merit increase. Yet the company apparently failed to investigate these facts. Under a competence-centered analysis. the company would have inquired into whether the sexually explicit cards, the unfavorable evaluatson. and the denied ment increase were all part of a pattern of conduct that created a discriminatory work environment for Kennedy based on her gender. As part of the inquiry, the company would have asked whether Pierce's conduct had the purpose or effect of demeaning or devaluing Kennedy's compelence based on her gender. To answer these questions, the company would have investigated Pierce's (and the company's) overall record in hinng. evaluating, paying, promoting, and dealing with other women, as well as any pnor complaunts of sexual overtures or other sexualized forms of alleged misconduct.

559. Id.

560. Kirstin Downey Grimsley, In Combating Sexual Harassment. Companies Someumes Overreact. WASH. POST, Dec. 23, 1996, at A1.

561. Asra Q. Nomani, Was Prof's Lecture Academic Freedom or Sex Harassment: A Male Student in California, Irked by 'Male-Bashing.' Asserts II Was the Latter. WALL. ST. J., Mar. 7. 1995. al AI.

562. Dirk Johnson, A Sexual Harassment Case To Test Acadenic Freedom. N.Y. TIMES, May II, 1994, at D23 (quoting a formal reprimand issued to the professor by the Chicago Theological Seminary). 563. See id. 
harassment law on the part of those who are concerned about protecting sexual expression ${ }^{564}$ or who, for less salutary reasons, oppose placing the power of accusation in the hands of women workers. Although some of the reported sexual harassment complaints may raise First Amendment concerns, that is not my focus here. ${ }^{565}$ My concern, instead, is the effect on gender relations. It gives feminism a bad name when men (or women) are fired for merely talking about sex at work. In my view, it is misguided to attempt to banish all hints of sexuality from the workplace. ${ }^{566}$ For one thing, it will not work. One does not have to be a Freudian to acknowledge that the old Taylorist belief that sexuality could be banished from the realm of the modern organization was incorrect; sexuality permeates organizations and, so long as organizations are made up of human beings, will continue to flourish in one form or another. $^{567}$

Even if all sexual interaction could be eradicated from the work world, this would not necessarily be desirable. Sexuality should not be conceptualized solely as a sphere of gender domination, but also as a potential arena of women's empowerment. ${ }^{568}$ If some men use sexual behavior as a weapon of gender struggle at work, one solution is for women to refuse to cede sexuality

564. See, e.g., Eugene Volokh, What Speech Does "Hostile Work Environment Harassment" Law Restrict?, 85 GEO. L.J. 627 (1997); Anthony Lewis, Time To Grow Up, N.Y. TIMES, Oct. 14, 1994, at A35; Francine Prose, Bad Behavior, N.Y. TIMES, Nov. 26, 1995, § 6 (Magazine), at 34.

565. It is interesting to observe that arguments that Title Vll law impermissibly restricts frec speech-arguments that were raised and rejected in the early days of the statute's enforcement-began to be revived only as sex-based harassment began to be conceptualized in terms of sexual content. Given this timing, it is conceivable that the prevailing sexualized understanding of harassment raises frec speech concerns that are greater than any such concerns that would be raised by the alternative, competence-centered account proposed here. Although this question deserves further research and reflection, it is beyond the scope of my inquiry here.

566. For a different analysis of harassment reaching the same conclusion about the inadvisability of attempting to eliminate all sexual expression from the workplace, see Franke, supra note 441, at 746-47.

567. See JefF Hearn \& Wendy Parkin, "SeX" at "WORK": The Power and Paradox of ORGANISATION SEXUALITY passim (1987); Gibson Burrell \& Jeff Hearn, The Sexuality of Organization, in THE SEXUALITY OF ORGANIZATION, supra note 410, at $1,13$.

568. More than a few feminists who support legal protection against sex-based harassment have begun to question the wisdom of attempting to banish all sexual interaction from the workplace; some have begun to envision and express sexuality as a potentially positive resource for women and other outsiders. See, e.g., CYNTHIA CockbuRn, In the Way of Women: MEN's Resistance to Sex Equaltty Within ORGANIZATIONS 159 (1993) ("“Opposition to sexual harassment is oniy one component of a sexual politics in the workplace.'. . . The long agenda for the women's movement in organizations must be to strengthen women's position and confidence in many different ways so that we can re-introduce our bodies, our sexuality and our emotions on our own terms." (quoting Rosemary Pringle, Bureaucracy, Rationality and Sexuality: The Case of Secretaries, in THE SEXUALITY OF ORGANIZATION, supra note 410, at 158, 166)); Pringle, supra, at 174-77 (arguing that desexualizing the workplace accepts the modernist imperative of rationality in which bureaucratic organizations replace arbitrary and personal authority with official and rationalistic hierarchies of position, and arguing that rather than banishing sexuality from the workplace, feminists should strive to reveal men's sexuality so as to discredit masculinity's claim to asexual rationality and to redefine the play of sexuality so that women become sexual subjects rather than only sexual objects); cf. BELL hOOKS, TEACHING To TRANSGRess: EdUCATION AS THE PRACTICE OF FREedOM 199 (1994) (urging professors to cultivate passion in their teaching and arguing that, "[t]o restore passion to the classroom, professors must find again the place of eros within ourselves and together allow the mind and body to feel and know desire"). 
as a source of male domination and to use it to turn the tables on oppressive men. History provides examples of women who successfully mobilized sexual conduct or expression as a way of undermining authoritarian male control in the workplace. ${ }^{569}$ Even more fundamentally, women and sympathetic men can work together to integrate the workforce. Research suggests that where men and women work alongside each other in balanced numbers, harassment is less of a problem. Workers in such settings report that sexual talk and joking occurs with frequency, but is not experienced as harassment. ${ }^{570}$

To some readers, it will seem too risky to acknowledge that the prevailing paradigm may encourage some overreaching. Some will fear that to concede that sexual expression does not always amount to gender-based discrimination creates problems of line drawing that are dangerous to women's interests. Yet, as we have already seen, relying on the sexual nature of alleged misconduct has not solved the problem of line drawing and has itself created problems of underinclusiveness. ${ }^{571}$ Furthermore, eliminating the current emphasis on the sexual content of harassment does not mean that sexual expression would always go unscrutinized. For one thing, the cause of action for quid pro quo harassment would remain unaffected by my approach; where a supervisor seeks to condition job benefits on sexual favors, the company would continue to be liable. For purposes of hostile work environment harassment, courts and companies would continue to review sexually explicit behavior, but they would examine it along with any challenged nonsexual behavior to determine whether all such activity, taken together, created a discriminatory work environment. Part of the relevant inquiry would be an examination of the larger workplace context-most importantly, the employers' past and present record of recruiting, hiring, promoting, evaluating, and paying women (and gendernonconforming men) on an equal basis. Male supervisors' or coworkers' deployment of sexual expression and activity in traditionally segregated job settings may raise alarm bells that would not sound in more integrated settings - particularly where such sexual activity is accompanied by other actions that denigrate the harassees' competence.

Courts should examine such structural linkages between sex-based harassment and other forms of gender stratification, rather than focusing so much attention on the sexual content of the alleged misconduct alone. Women

569. Ruth Cavendish provides a wonderful example of the use of sexuality by women factory workers whose supervisors attempted to exercise authoritarian control by prohibiting the women from lining up in front of the time clock even a few minutes before quitting time. When the supervisors posted a male chargehand in front of the clock, one of the women marched straight up to him and pulled down his pants. The rest of the women bared their bellies and pretended to be pregnant. knowing that pregnant women were permitted to stand at the front of the line. See CAVENDISH, supra note 395, al 89-90.

570. See GUTEK, supra note 13, at 143 tbl.2 (showing that. even though a nandom sample of women working in sex-integrated settings experienced frequent sexual talk or joking. none of them considered sexual harassment to be a major problem at work).

571. See supra Section IIl.B. 
should not have to present themselves as Sunday-school teachers in order to comport with the image of the good victim. But neither should women (or men) be able to sue because they are offended by someone else's sexual conversation or gestures. A competence-centered paradigm alleviates this problem by focusing attention away from sexuality as such and toward gender inequality in work roles. That is where Title VII's focus properly lies.

\section{CONCLUSION: TOWARD IMPLEMENTING THE NEW ACCOUNT}

The new account of hostile work environment harassment would restore harassment law to Title VII's original purpose. From the beginning, the central purpose of the statute's prohibition against sex discrimination has been to enable everyone-regardless of their identities as men or women, or their personae as masculine or feminine-to pursue their chosen endeavors on equal, empowering terms.

Over time, with the emergence of the sexual desire-dominance paradigm, harassment law has moved away from this purpose. Indeed, the story of how this paradigm came to predominate may hold important lessons about the paradoxes of legal reform. Influenced by early feminist accounts that politicized sexual violations long-shielded from scrutiny, courts overcame their initial resistance to recognizing a supervisor's demands for sexual favors as a form of gender discrimination and created a cause of action for quid pro quo sexual harassment. As I have emphasized, this represented a step forward for women: It was important for courts to abandon the view of sexuality as a purely privatized matter and to acknowledge that gender-based discrimination at work can take the form of employer-sanctioned sexual advances.

Ultimately, however, judicial recognition that workplace sexual relations can be infused with gender discrimination evolved into an account that collapsed the two. Courts began to view sexual advances as the quintessential form of gender-based harassment and to suspect many less troubling sexual interactions of an inevitable gender bias. Undoubtedly, some early feminist accounts that portrayed heterosexual sexual relations as a primary force disadvantaging women resonated with the conservative proclivities of many judges, who shared the supposition that heterosexual sexual relations are suffused with domination and danger for women. Such a perspective did no harm in the context of quid pro quo harassment cases; companies should be held responsible when supervisors condition employment benefits on sexual favors. Yet, when courts and advocates transposed the emphasis on sexual advances to hostile work environment harassment cases, they created a framework that has proven to be more limiting than empowering for its intended beneficiaries.

The sexual desire-dominance paradigm is too narrow. Although its triumph has been viewed as a feminist victory, that success has rung hollow for the 
many women (and men) who experience forms of harassment that it does not envision. Most centrally, the paradigm has failed large numbers of people who are not subjected to sexual abuse, but whose competence as workers is constantly thrust into conflict with their identities as women or gender-nonconforming men. We need an account of hostile work environment harassment that recognizes that sexuality is only one tool that male workers can deploy in a struggle to maintain the masculine composition and image of more highly rewarded jobs. Conversely, the account should acknowledge that sexuality is not inherently gender-biased; in some contexts, it can be a neutral or even positive resource for women (and nonconforming men). I have offered a new paradigm for hostile work environment harassment that takes these dynamics into account.

The competence-centered account deflects attention from the sexual content of workplace conduct and refocuses it on the link between hostile work environment harassment and job segregation by sex. This account emphasizes the role of sexual and nonsexual forms of harassment in maintaining favored lines of work as male-dominated. It also highlights the competenceundermining character of such harassment. Our nation's history of excluding women from many of the most highly rewarded forms of employment has conferred on male workers a sense of entitlement to such jobs. By castigating women as less competent to perform such work, hostile work environment harassment warns women away or incorporates them as inferiors. In doing so, harassment upholds the idealized masculine image of the work and those who do it. Harassment is thus both a cause and a consequence of larger forms of gender-based stratification of work, such as job segregation by sex and the accompanying wage and status inequalities.

Implementing the new account would not be difficult; it would require no greater resources than other Title VII sex discrimination cases. Indeed, as I have emphasized throughout, the new account seeks merely to restore harassment law to Title VII's traditional focus on "break[ing] down old patterns of ... segregation and hierarchy." ${ }^{572}$ Doing so demands primarily a shift in perspective. It entails reevaluating what type of evidence is relevant and examining that evidence through new lenses.

The new account directs that, as in Berkman v. Ciry of New York, ${ }^{\text {s73 }}$ courts pay more attention to the larger structural context of the workplace, including the company's record on job segregation by sex. Such contextual information is frequently absent from hostile work environment harassment cases, in part because the sexual desire-dominance paradigm has led to an isolating focus on sexual abuse that renders such information irrelevant. As we

572. Johnson v. Transportation Agency, 480 U.S. 616, 628 (1987). IV.C.

573. 580 F. Supp. 226 (E.D.N.Y. 1983), aff'd. 755 F.2d 913 (2d Cir. 1985), discussed supra Section 
have seen, the courts have disaggregated sexual conduct from other forms of sex-based harassment and discrimination. The severing of the claims and evidence along such sexualized lines is both a signal and a further source of the problem. Once courts hold that only sexual conduct may contribute to creating a hostile work environment and conclude that nonsexual misconduct must be considered (if at all) as a separate form of disparate treatment, it is clear that information about the history and structure of any gender stratification in the workforce will not lend perspective to the court's view of harassment.

To obtain such perspective and implement the new account, the courts should first take one important step: They should cease the disaggregation of hostile work environment harassment and other forms of discrimination along sexual lines. Hostile work environment harassment is simply a form of discrimination, one created to redress discriminatory working conditions that do not necessarily affect a tangible job detriment. Judicial decisions that have strayed from this insight and required elaborate elements to prove a hostile environment claim have distorted the law and diverted it from its remedial function. To restore the proper remedial focus, courts should consider all of the challenged conduct-sexual and nonsexual-in connection with the hostile work environment claim. For purposes of that claim, the issue should not be whether the challenged conduct was sexual in nature, whether it reflected gender "animus," or whether any of it effected a tangible job detriment. The question is simply whether all the alleged harassment and discrimination, taken together, created a discriminatory work environment based on gender.

There are a few ways courts can move toward such a unified approach. First, judges should rely on McKinney v. Dole $e^{574}$ and its progeny to examine as part of the hostile work environment claim any alleged nonsexual misconduct that is not challenged as a separate form of discrimination. As we have seen, nonsexual conduct that does not effect a tangible job detriment frequently evades judicial scrutiny; many courts conclude that it does not provide the basis for an independent disparate treatment (or presumably disparate impact) claim, ${ }^{575}$ while also excluding it from the hostile work environment claim on the ground that it is not sexual in nature. Under the McKinney rule, conduct such as nonsexual hazing or assault, work sabotage, or failure to provide informal training, which may not provide the basis for an independent disparate treatment claim, would count toward establishing a hostile work environment.

Second, regardless of whether McKinney requires it, courts should also consider whether any nonsexual conduct that plaintiffs are or could be challenging as an independent form of discrimination has contributed to

574. 765 F.2d I129 (D.C. Cir. 1985), discussed supra text accompanying notes 247-249, 296-298.

575. See supra notes $147-148$ and accompanying text. 
creating a discriminatory work environment. We have seen that in many work settings, practices such as differential training, evaluation, and promotion not only directly harm the women subjected to them, but may also indirectly create an atmosphere of inferiority for the victims of discrimination and other women in the workplace. Thus, courts should consider whether any such practices have contributed to a generally hostile work environment based on gender (and, conversely, should consider any evidence of such overall hostility toward women in determining whether any particular practices constitute independent forms of discrimination based on gender). ${ }^{576}$ Proof of discrimination against some women may help establish a hostile work environment involving others. Similarly, evidence that may not suffice to establish an independent disparate treatment (or disparate impact) violation may nonetheless serve to bolster other proof of a hostile work environment. Of course, by identifying all the practices that contributed to that environment, courts can also fashion a more effective remedy.

Third, beyond considering all the sexual and nonsexual conduct together, courts should also consolidate the trend away from disaggregation by streamlining the elements of a cause of action for hostile work environment harassment. The ultimate question is whether the challenged conduct created a discriminatory work environment based on gender. Toward that end, a simplified cause of action should require only three elements: (1) Causation-Did the challenged conduct occur because of sex (or gender)? (2) Harm-Was the conduct sufficiently harmful to ".alter the conditions of . . . employment and create an abusive working environment"'?" Responsibility-Was it conduct for which the employer is legally responsible? ? $^{578}$

576. See, e.g., Olmer v. Beef Processors, 66 Fed. Empl. Prac. Cases (BNA) 843. 847 (D. Neb. 1994) (relying on the history of egregious nonsexual harassment of the plaintiff maintenance crew worker to supply an inference that her discharge was based on sex): Danna v. New York Tel. Co., 752 F. Supp. 594. 614 (S.D.N.Y. 1990) (relying on the evidence of hostile and sexist comments introduced in connection with the plaintiff telephone worker's harassment claim for purposes of determining that her demotion was discriminatory); cf. Margaret E. Johnson. Comment, A Umufied Approach to Causation in Disparate Treatment Cases: Using Sexual Harassment by Supenisors as the Causal Nexus for the Discriminatory Motivating Factor in Mixed Motives Cases, 1993 WIS. L. REV. 231 (arguing that where a plaintiff proves harassment, cours should assume that sex was a motivating factor in any related adverse employment decision and should shift the burden of persuasion to the employer to show that the company would have made the same decision even in the absence of the proven sexism).

577. Meritor Sav. Bank v. Vinson, 477 U.S. 57.67 (1986) (quoting Henson v. Dundec, 682 F.2d 897. 904 (11th Cir. 1982)).

578. Cf. supra note 150 and accompanying text (discussing the concept of employer responsibility). Although a full analysis of this issue is beyond the scope of this Aricle, 1 is important to recognize that the courts' tendency to place undue emphasis on sexual advances may affect the resolution of the employer responsibility element, as well as the causation and harm elements. In considenng whether to attnbute constructive notice of the alleged misconduct to the employer, for example, courts may consider much of the same evidence that they use to determine whether the conduct is severe or pervastve enough to be actionable. Indeed, the Supreme Court has agreed to consıder whether a finding that the harassment is sufficiently severe or pervasive automatically establishes constructive notice for purposes of employer liability. See Faragher v. City of Boca Raton, III F.3d 1530, 1538 (1/ th Cir.) (concluding that the district 
For purposes of causation, the courts should deemphasize the current focus on whether the challenged conduct is sexual in nature. To determine whether the conduct is based on sex within the meaning of Title VII, they should inquire instead into whether it embodies gender-based expectations for the workers or work involved. The touchstone is Price Waterhouse $v$. Hopkins. ${ }^{579}$ Although the inquiry will vary depending on the particular fact situation, relevant questions may include the following: Are the women expected to present themselves in ways that would be considered inappropriate for a male worker? Are they depicted as less competent than the men? Are men depicted or expected to present themselves in ways that reflect a narrow, preconceived notion of proper manhood? In many cases, it will be helpful to ask whether the conduct helps maintain a male-dominated composition for the job or a preconceived masculine image of competence for the work involved. ${ }^{580}$

As part of this causation inquiry, the larger structural context of the workplace will be very relevant. In the context of a workplace with longstanding inequality, a potentially "stray remark[]"581 about women or even an apparently gender-neutral act of hazing may assume heightened causal significance. Consequently, courts should examine the record for structural indicia of gender inequality at work. For example: Was there a history of discrimination or exclusion of women from the relevant occupation or field, the workplace, or the job title? Were women present in skewed sex ratios, which meant that they were likely to find themselves unwelcome among the men who outnumbered them? Even if women were well-represented, had supervisory positions or other positions of authority traditionally been held by

court erred in holding that "simply because conduct is pervasive enough to create an abusive work environment the employer should be charged with knowledge of the conduct"), cert. granted, $118 \mathrm{~S}$. Ct. 438 (1997); see also Dornhecker v. Malibu Grand Prix Corp., 828 F.2d 307, 309 (Sth Cir. 1987) (holding that the severity of the alleged misconduct is relevant to determining the adequacy of the employer's response for purposes of determining employer liability, and concluding that a company's assurance that the plaintiff would not have to work with her harasser once the current business trip was over was a sufficient response where she "was not propositioned, [and] she was not placed in any threatening situation"). To the extent that the two inquiries overlap, my concerns about the courts' tendency to overlook nonsexual forms of harassment also apply to the employer responsibility element.

579. 490 U.S. 228 (1989).

580. Conversely, where harassment occurs in the context of a predominantiy female job setting, it may serve to reinforce the female-dominated makeup of the job or traditionally feminine image of what the work entails. Such effects may occur at the hands of male supervisors whose conduct toward femalc workers pressures them to conform to preconceived notions of appropriate feminine behavior for someone who holds the job. See, e.g., EEOC v. Sage Realty, 521 F. Supp. 263, 267 (S.D.N.Y. 1981) (requiring the incumbent of an all-female lobby attendant job to appear sexy by wearing a revealing costume that subjected her to harassment by male onlookers). Or, conceivably, such effects may occur at the hands of female supervisors or workers who harass outnumbered male workers by pressuring them to conform 10 preconceived notions of masculine behavior that target them as "different" from those who are expected to hold the job. See, e.g., Gross, supra note 412 (describing a hostile work environment case brought by male employees of a Jenny Craig weight-loss center, who claimed that their female supervisor forced them to perform traditionally male activities, like changing tires, while the supervisor and female employees engaged in female-oriented conversations and activities that excluded them).

581. Price Waterhouse, 490 U.S. at 277 (O'Connor, J., concurring). 
men? If so, how had that authority been defined and exercised? Had managers and supervisors treated women with equal respect and dignity or had they subjected them to paternalistic or authoritarian forms of supervision? Conversely, when women were in positions of authority, had male subordinates extended them their respect and cooperation or had they instead challenged them and refused to take direction? What was the record and reputation of women in the larger field? Had women's talents been overlooked or denigrated or had their accomplishments been celebrated on an equal basis with men's? Finally, of course, the courts should examine the particular situation of the plaintiffs: Did the conduct have the purpose or effect of undermining the women's "right to participate in the work place on [an] equal footing"? ?82

In cases involving harassment of women workers, there is an efficient way for courts to operationalize the insight that the larger workplace context matters: At least in close cases, courts could assume that the challenged conduct is gender-based where it is directed at women who work in "traditionally segregated job categories." 583 We have already seen that most courts are willing to assume that conduct that is sexual in content is based on sex within the meaning of Title VII. I have criticized this assumption for creating a two-tiered structure of causation in which nonsexual forms of harassment fade from view. In order to remedy this omission, the courts should extend a parallel assumption to nonsexual conduct that occurs in sex-segregated job settings. Such an assumption, which could take the form of a rebuttable presumption, is a sensible way to recognize the proven link between hostile work environment harassment and job segregation by sex. As we have seen, conduct that may appear innocuous or even gender-neutral may, in male-dominated settings, be part of a campaign to drive away women or denigrate their competence. Similar pressures may exist in female-dominated settings.

In cases involving same-sex harassment, the causation inquiry should also turn on whether the challenged conduct is based on gender (rather than whether it is sexual in content). But here the relevant evidence may look different. In many cases involving harassment of men by men, the harassment will have the purpose or effect of denigrating the harassee's manhood. Antigay ridicule will almost always do so, but other types of evidence may also suggest that the harassees were targeted because something about them threatened the dominant workers' views about the suitable masculine image for those who hold the job. The harassees may be perceived to be too weak, too young, too old, too asexual, too soft, or even too identified with women's interests to fit the mold. In other cases, the harassment itself may utilize gender-based images

582. Scott v. Sears, Roebuck \& Co., 798 F.2d 210, 213 (7th Cir. 1986).

583. Johnson v. Transportation Agency, 480 U.S. 616, 630 (1987) (citing United Steelworkers v. Weber, 443 U.S. 193, 209 (1979)). 
as a form of denigration or competition (such as calling men epithets typically reserved for women). Regardless of whether the harassment assumes an explicitly gender-based content or more subtly attacks people because of their failure to conform to the harassers' image of proper manly behavior, the harassment is based on gender. The new account would recognize it as such.

Just as the new account would decenter the focus on sexuality in connection with the question of causation, so too would it do so in connection with the question of harm. In considering whether the challenged conduct is sufficiently harmful to be actionable, the new account would deflect attention away from whether the conduct is sexually offensive in favor of a focus on whether it makes it more difficult for the harassees to do the job because of their gender. Indeed, under the new account, courts would recognize that, rather than signaling genuine sexual or romantic interest, even sexual advances and other sexually oriented conduct may serve as a way of marking women or nonconforming men as different and less adequate for the job.

Courts would also understand that overtly sexual harassment is not the only, or even the most common, form of harassment experienced by women or nonconforming men on the job. Once the sexual focus is abandoned, many new forms of gender-based harassment and harm may come to light. Importantly, judges would understand from the outset that hostile work environment harassment frequently has the aim or effect of denigrating the harassee's work competence. The spectrum of gender-based, competenceundermining conduct sweeps broadly; the form of the conduct varies with the occupational setting. Thus, judges should not only exhibit sensitivity to the role of such competence-undermining conduct in creating hostile work environments, they should also scrutinize carefully employers' attempts to justify adverse treatment of women or harassed male workers on the ground that such workers are less competent. Particularly where a history of job segregation by sex or other structural indicia of gender stratification are present, a harassee's incompetence may be as likely to be the consequence as the cause of her negative treatment. ${ }^{584}$ At a minimum, courts should evaluate whether the gender-based mistreatment was a significant factor in creating any diminished performance.

In contrast to the prevailing paradigm, the new account would render any inquiry into the "unwelcomeness" of the challenged conduct irrelevant. Once courts reconceptualize environmental harassment as an assault on competence, the unwelcomeness inquiry no longer makes sense. Although some people may welcome expressions of sexual interest, few employees invite conduct that attacks their work performance in the name of gender conformity.

584. For an analysis of this point that refers to the interactional quality of workplace harassment and diminished work performance as dynamic discrimination, see Mark Kelman, Concepts of Discrimination in "General Ability" Job Testing, 104 HARV. L. REV. 1157, 1170-72 (1991). 
Although no single decision has analyzed hostile work environment harassment in precisely these terms, there is support for the new account in the case law. As I discussed earlier, a number of courts of appeals have followed McKinney and held that conduct need not be sexual in nature to contribute to a hostile work environment. ${ }^{585}$ It is time for courts to take this point seriously and to utilize the McKinney reasoning to end the disaggregated treatment of sexual and nonsexual forms of alleged misconduct. The Supreme Court's decision in Harris v. Forklift Systems, Inc. ${ }^{586}$ approves such a focus; the opinion acknowledges that hostile work environment harassment is simply a form of gender discrimination. As the Court observed, "The phrase 'terms, conditions, or privileges of employment' evinces a congressional intent to strike at the entire spectrum of disparate treatment of men and women in employment, which includes requiring people to work in a discriminatorily hostile or abusive environment." 587

Indeed, Justice O'Connor's opinion for the majority in Harris highlights the competence-undermining effect of such environments. It notes that "[a] discriminatorily abusive work environment, even one that does not seriously affect employees' psychological well-being, can and often will detract from employees' job performance, discourage employees from remaining on the job, or keep them from advancing in their careers." 388 Justice Ginsburg's concurrence underscores the point: "The critical issue . . is whether members of one sex are exposed to disadvantageous terms or conditions of employment to which members of the other sex are not exposed." 589 To establish a hostile work environment, "[i]t suffices to prove that a reasonable person subjected to the discriminatory conduct would find, as the plaintiff did, that the harassment so altered working conditions as to "[make] it more difficult to do the job." 590

These passages from Harris suggest something close to the simplified standard I am urging for hostile work environment harassment. Some lower courts have used such a simplified approach. ${ }^{591}$ Others have acknowledged,

585. See supra notes 250,269 , and accompanying text.

586. 510 U.S. 17 (1993), discussed supra Section Il.A.

587. Id. at 21 (intemal quotation marks omitted).

588. Id. at 22.

589. Id. at 25 (Ginsburg, J., concurring).

590. Id. (quoting Davis v. Monsanto Chem. Co., 858 F.2d 345. 349 (6th Cir. 1988)).

591. Indeed, some courts used such a simplified approach in carly challenges to disenminatory working conditions. See, e.g., Rimedio v. Revlon, Inc., S28 F. Supp. 1380. 1383 (S.D. Ohio 1982) (holding a company liable where the plaintiff account manager charged that her supervisor "harassed her, threatened her with loss of her job, prevented her from exereising the authority and responsibility commensurale with her position and generally treated her without respect"); EEOC v. Judson Stcel Co., 33 Fair Empl. Prac. Cas. (BNA) 1286, 1295 (N.D. Cal. 1982) (holding a company liable where the plaintiff bricklayers were treated differently in the assignment of work, overtime, breaks, and other day-to-day conditions of employment, and were also subjected to harassment and sexual advances by their supervisor, because such actions "created a working environment fraught with sex bias ... thus violating (the plaintiffs"] nght to work in a nondiscriminatory environment"); see also Porta v. Rollins Envtl. Serv. (NJ), Inc.. 654 F. Supp. 1275, 1282 (D.N.J. 1987) (concluding that the sole female managerial employee's claum that she was 
like the Harris Court, that part of what can make a work environment harmful is harassment that makes it more difficult for the harassee to do the job. ${ }^{592}$ Some courts have exhibited skepticism toward employers' attempts to attribute women's adverse treatment to their own incompetence, where there is evidence that any problems in performance are themselves an artifact of gender harassment or discrimination. ${ }^{593}$ Others have jettisoned the unwelcomeness issue, acknowledging that a woman worker's use of profanity or other "unladylike" behavior should not be deemed to provoke hostile, harassing conduct from her coworkers-whether or not that harassment is sexual in nature. $^{594}$ In addition, the Supreme Court itself recently held that gender-based, male-on-male harassment may be actionable, regardless of whether it is motivated by sexual designs. ${ }^{595}$ Finally, and most importantly,

subjected to a hostile work environment in the form of "crude comments and humiliating treatment and [her supervisor's statement] that her opinion was not respected because she was a woman" was part of a continuing violation), aff'd mem., 845 F.2d 1014 (3d Cir. 1988). Perhaps because these cases were decided before the judicial trend toward disaggregation of sexual and nonsexual conduct into separate hostile work environment and disparate treatment claims was firmly established, the courts felt free to adopt a simpler, common sense inquiry into whether all the alleged misconduct had rendered the plaintiff's work environment discriminatory based on sex.

592. See, e.g., Flom v. Waste Mgmt., Inc., No. 95 C 1924, 1997 WL 137174, at *5 (N.D. Ill. Mar. 24,1997 ) ("A victim does not need to prove a tangible productivity decline; instead the harassment must merely "make it more difficult on the job."' (quoting Harris, 510 U.S. at 25 (Ginsburg, J., concurring))); Guy v. Day Prod. Inc., 1995 U.S. Dist. LEXIS 17620, at *11 (E.D. Pa. Nov. 19, 1995) (concluding that the harassment was sufficiently harmful to be actionable where the plaintiff manager testified that it "'added incredibly' to what she had to deal with in the workplace, thus making her job much more difficult and stressful, and that such behavior 'diluted' her energy" and "interfered with her ability to do her job").

593. See, e.g., Delgado v. Lehman, 665 F. Supp. 460, 467 (E.D. Va. 1987) ("Having created a hostile working environment, defendant cannot complain that Delgado failed to perform. "An employer cannot use an employee's diminished work performance as a legitimate basis for removal where the diminution is the direct result of the employer's discriminatory behavior."' (citations omitted)); Rimedio, 528 F. Supp. at 1389 ("Defendants often argue, as is argued here, that the women just do not perform a job as well, and that is the reason for the disparate treatment. Such a defense must be closely scrutinized."); $c f$. Harris $v$. International Paper Co., 765 F. Supp. 1509, 1524 (D. Me. 1991) (rejecting the argument that AfricanAmerican mill workers were not promoted because they were less qualified by noting that there existed "substantial evidence supporting the conclusion that Defendant's decisions neither to train nor promotc Plaintiffs were susceptible to racial bias and were, in fact, corrupted by racial bias").

594. See, e.g., Carr v. Allison Gas Turbine Div., Gen. Motors Corp., 32 F.3d 1007, 1011 (7th Cir. 1994) (concluding that a female drill operator's "unladylike" use of profanity and dirty jokes did not justify the conclusion that she welcomed her harassment where her "violent resentment of the conduct of her male coworkers toward her [was] plain"); id. at 1008 (stating that "welcome sexual harassment" is an oxymoron); Stacks v. Southwestern Bell Yellow Pages, Inc., 27 F.3d 1316, 1325-26 (8th Cir. 1994) (recognizing that hostile work environment harassment may be significantly comprised of nonsexual conduct such as making a sales representative feel worthless despite her excellent record, and rejecting as irrelevant the defendant company's argument that the plaintiff's private sex life showed she had "welcomed" the harassment).

595. See Oncale v. Sundowner Offshore Servs., Inc., No. 96-568, 1998 WL 88039 (U.S. Mar. 4, 1998). In Oncale, the Supreme Court unanimously reversed a Fifth Circuit decision that had held that a male supervisor's harassment of a male subordinate can never constitute gender-based discrimination in violation of Title VII. The Court held that "nothing in Title VII necessarily bars a claim of discrimination "because of . . . sex' merely because the plaintiff and the defendant . . . are of the same sex." ld. at *2 (quoting 42 U.S.C. $\$ 2000-e(a)(1)(1994))$.

Several features of the Court's analysis conform to, and provide additional support for, the approach proposed in this Article. First, the Court emphasized that hostile work environment harassment is simply a form of sex discrimination and that Title VII protects men as well as women against "'the entire spectrum of disparate treatment . . . in employment."' Id. at *2 (quoting Meritor Sav. Bank v. Vinson, 477 U.S. 57 , 64 (1986)). Second, the Court made clear that regardless of whether harassment occurs between men and 
a number of courts have recognized the link between hostile work environment harassment and job segregation. ${ }^{5 \%}$ Some of the most perceptive judges have even acknowledged the role of harassment in preserving the masculine image of traditionally segregated jobs (and the men who hold them) ${ }^{597}$

It is cause for optimism that, in spite of the prevailing paradigm, some courts are struggling toward a broader understanding of hostile work environment harassment. Yet, it is not only courts, but also feminists and sympathetic lawyers and activists, who must reconceptualize sexual harassment. As the history of harassment law shows, it was the work of such people that produced the political, cultural, and legal climate conducive to the prevailing paradigm. To change that paradigm, these groups must once again take the lead. We must envision more than a world in which women are protected from sexual violation. We must also envision a world in which all women and the least powerful men are fully enabled to work as equals in whatever endeavors their hearts and minds desire.

women or between members of the same sex, proof of sex-based hostile work environment harassment does not turn on proof that the alleged misconduct was sexual in content or design. "We have never held that workplace harassment, even harassment between men and women, is automatically disenmination because of sex merely because the words used have sexual content or connotations." Id. at •3. By the same token. stated the Court, "harassing conduct need not be motivated by sexual desire to suppon an inference of discrimination on the basis of sex." Id. at *4. Although the Court did not specifically conceptualize male-on-male harassment, for example, as a way for the harassers to wam away men who fail to conform to preconceived notions of suitable manliness for the job, the Court's analysis leaves the lower courts free to focus on such gender-based, but not necessarily sexual, dynamics of same-sex harassment. See. e.g. . Doc v. City of Belleville, 119 F.3d 563, 581 (7th Cir. 1997) (recognizing that "a man who is harassed because his voice is soft, his physique is slight, his hair is long, or because in some other respect he exhibits his masculinity in a way that does not meet his coworkers' idea of how men are 10 appear and behave, is harassed 'because of' his sex"); Zalewski v. Overlook Hosp., 692 A.2d 131. 135 (NJ. Super. Cl. 1996) (recognizing that where the plaintiff's male coworkers harassed him "because they believed hum to be a virgin and effeminate," a jury could properly conclude that he was discriminated agaunst "because he was a male who did not behave as they perceived a male should behave, i.e., that they diseriminated agannst him based on gender stereotyping").

596. See, e.g., Kyriazi v. Westem Elec. Co., 461 F. Supp. 894. 933-34 (D.NJ. 1978) (rejectung the company's argument that an engineer was harassed and terminated because of psychological instability and finding instead that she was harassed because of her refusal to aceept second-class treatment in a company that was thoroughly sex-segregated from top to bottom), aff'd. 647 F.2d 388 (3d Cir. 1981); Accards v. Superior Court, 21 Cal. Rptr. 2d 292, 296 (Ct. App. 1993) (recognizing that the hostule work environment to which a policewoman was subjected amounted to a campaign "founded upon the department's unwniten policy that law enforement has traditionally been a 'man's job' and, hence. 'no women need apply'").

597. See, e.g., Sims v. Montgomery County Comm'n. 766 F. Supp. 1052. 1075 (M.D. Ala. 1990) (recognizing that the defendant sheriff department's practice of harassing women and discouraging them from advancement was "based on a belief . . . that women should not be [law enforcement] officers because they are less capable than men physically and mentally"): Lenihan v. City of New York. 636 F. Supp. 998. 1010 (S.D.N.Y. 1985) (concluding that, at the time the plaintiff was referred for psychological evaluation. "[t]here was ... a general sentiment among many officers, including (the captasn], that women could not adequately perform as full-duty police officers"): Berkman v. City of New York. 580 F. Supp. 226. 230 (E.D.N.Y. 1983) (concluding that "the officers of the Deparment responsible for [the plantuff firefighters") training and evaluation instead deliberately set out to re-examine [the plaintiffs'] physical capacitues to be firefighters"), aff'd, 755 F.2d 913 (2d Cir. 1985). 
